\title{
Preferences for forest-based biodiversity and ecosystem insurance services in the Hainich National Park region
}

\author{
Dissertation \\ to obtain a Dr. rer. nat. degree \\ PhD-programme 'Biological diversity \& Ecology', \\ Department of Biology, Faculty of Mathematics \& Science, \\ Georg-August-Universität, Göttingen, Germany
}

by

Sandra Rajmis

born in Hildesheim, Germany

Göttingen 2008 
Almost with exception, everything human beings undertake involves a choice, including the choice not to choose. (David Hensher, John Rose and William Greene) 


\section{D7}

$1^{\text {st }}$ referee: Prof. Dr. Rainer Marggraf (Universität Göttingen)

$2^{\text {nd }}$ referee: Prof. Dr. Christoph Leuschner (Universität Göttingen)

Date of disputation: November, 6th 2008

Author:

Sandra Rajmis

Dipl. Umweltwissenschaftlerin (Universität)

Master of Environmental Sciences

Contact information:

Environmental and Resource Economics Research Group

Department of Agricultural Economics und Rural Development

Platz der Göttinger Sieben 5

D-37073 Göttingen, Germany

Tel: ++49-551-394579

Email: srajmis@uni-goettingen.de 
It is a challenge to estimate economic benefits of biodiversity, ecosystems and ecosystem services to society. This is particularly the case if biodiversity and functioning ecosystems are considered as 'ecological insurance' to society and human-well being because it is an unfamiliar benefit. In the following, the 'ecological insurance' provided by biodiversity and functioning ecosystems is brought into focus as protection against risks. Besides more or less 'known' risks such as invasive species, pest outbreaks, diseases and storm risks, less 'known' risks such as some effects of climate change or even less 'unknown' risks exist. For so called Pythia- und Pandora risks (WBGU 1999:10) it is principally unknown if, how, when, where, and how badly they strike. These risks are unknown. If they occur, they may cause potentially catastrophic disruptions in the provisioning of humans with ecosystem services. It has been shown that at least partial 'ecological insurance' against such risks is possible, mainly by biological diversity and, more generally, the capacity of ecological systems to self-organise. But how much social and economic resources should be committed to 'ecological insurance'? A Choice Experiment (CE) (stated preference method) was used to quantify economic preferences for forest biodiversitybased ecosystem insurance services in the area of Hainich National Park, Thuringia (Germany).

A representative sample of 302 respondents was interviewed face-to-face in autumn 2006. Before correction of $6.6 \%$ protest responses, Nested Logit analysis shows that local residents state an average annual willingness-to-pay (WTP) for insurance services against climate change by afforestation of $21.43 € / \mathrm{yr}(\mathrm{p}<0.001)$, for increasing insurance services of forests against insect pests and storms of $27.54 € / y(p<0.001)$, and for increasing insurance services against unknown risks of $16.83 € / y(p<0.001)$. Residents are willing-to-pay $9.59 € / \mathrm{yr}(\mathrm{p}<0.05)$ for control measures limiting obvious 'dangerous' invasive plants such as the Giant Hogweed (Heracleum mantegazzianum) when compared to a more aggressive eradication program. 


\section{Acknowledgement}

Many people supported me in memorable ways during my $\mathrm{PhD}$ studies in the past three years in Göttingen. First of all, I am grateful to Dr. Jan Barkmann for his never ending support, guidance and inspiring discussions during all phases of the study and Prof. Dr. Rainer Marggraf for his supervision, support and patience. I also appreciate Prof. Dr. Christoph Leuschner and Bernd Raufeisen for technical support in graphic design in the creation process of the choice cards. I want to thank Prof. Dr. Dörthe Krömker for helpful comments and the DFG (German Research Foundation) for funding.

Furthermore, I am grateful to

- the Department of Didactics of Biology for sharing their resources, special thanks to Prof. Dr. Susanne Bögeholz, Susanne Menzel and Sabina Eggert

- Jiong Yan for her long-term friendship and support in all four phases of the study

- Christine Schnorrer for her help and support

- 10 anonymous students of Georg-August-Universität Göttingen for first challenging preliminary test-interviews

- further, 481 anonymous participants of the qualitative survey, pre-test, pilot study and main study and four anonymous enumerators who supported me in conducting the pilot and main-study interviews

- Inga Krämer and Meik Meissner for their support and enjoyable cooking evenings during the main study

- DFG research group 1086 for adventurous days in the field

- Manfred Großmann and Tourist-Information Bad Langensalza for general support during the preparation of the main study

- the working group on Environmental and Resource Economics for fruitful discussions and support, especially thanks to Claudia Cerda, Klaus Glenk, Jan Freese, Frank v. Walter and Manuel Thiel

- My bicycle for not giving up during the last phase of the main study in December 2006 


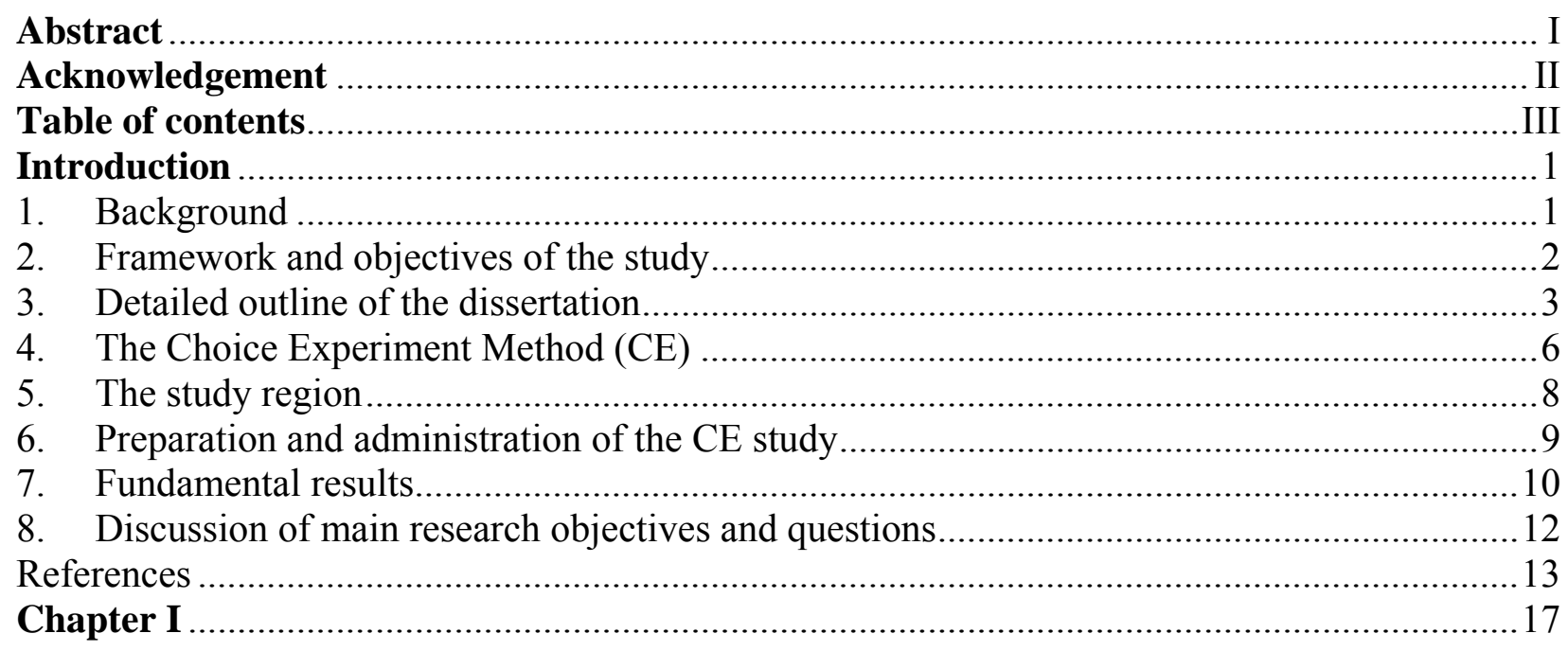

Utilisation of Grounded Theory Methodology for the development of a Choice Experiment:

Preliminary studies on the insurance value of biodiversity .................................................... 17

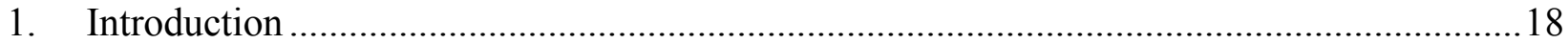

2. Improving stated preference survey instruments using qualitative research..........................20

2.1 Strategies of Grounded Theory Methodology (GTM): Analytic tools ...........................20

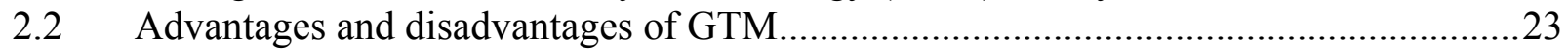

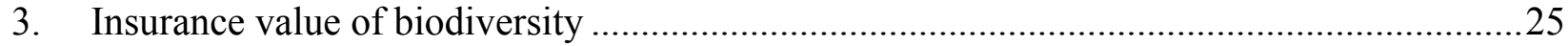

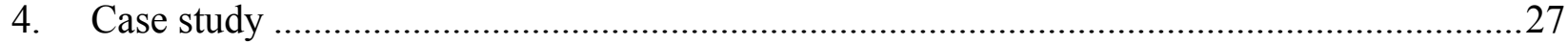

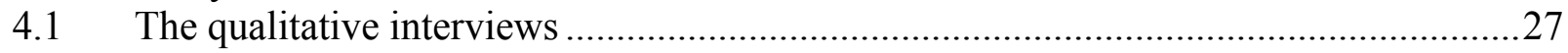

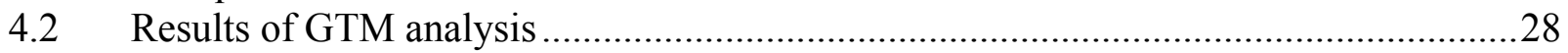

4.3 Qualitative results in attribute design............................................................................32

4.4 Building blocks for communicating the insurance concept ..........................................37

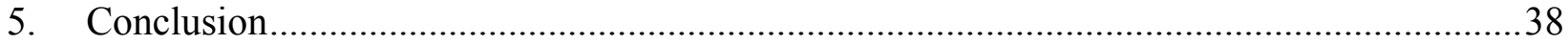

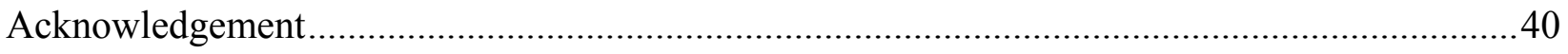

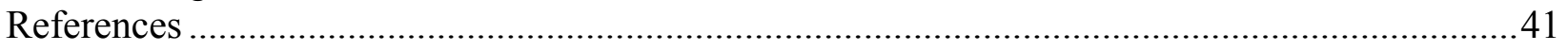

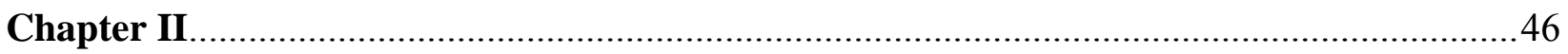

Der ökonomische Wert von Versicherungsdienstleistungen der Biodiversität gegen bekannte und unbekannte Risiken am Beispiel des Hainich National Parks (Thüringen) ...46

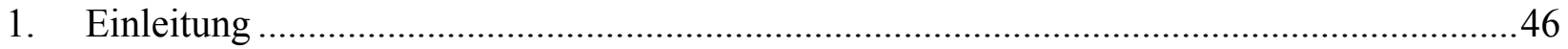

2. Methodischer Hintergrund: Das Choice Experiment ..............................................................4

3. Auswahl der Umweltgüter bzw. ökosystemaren Dienstleistungen ..........................................49

4. Durchführung und Auswertung des Choice Experiments ...................................................50

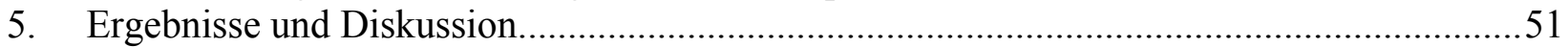

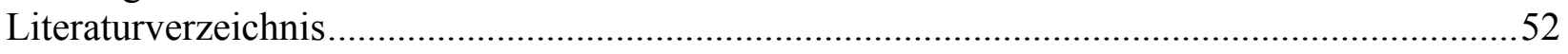


Forest-management measures to mitigate climate change or to adapt to its effects: monetary preferences in the user community around Hainich National Park, Germany ....54

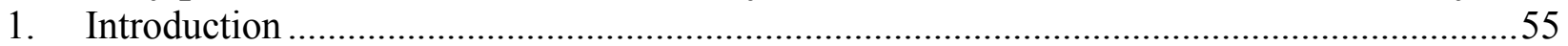

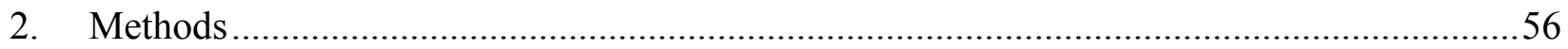

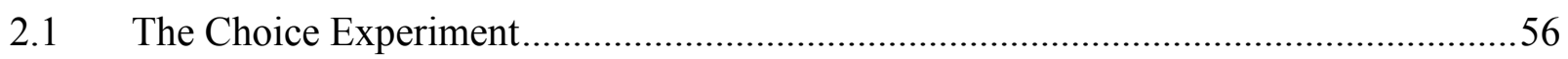

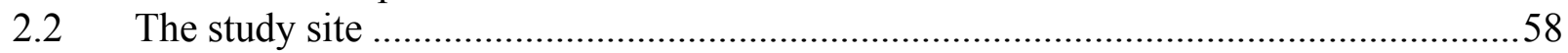

2.3 Measures of climate change mitigation and adaptation ..........................................59

2.3.1 Mitigation: Additional carbon sequestration by afforestation..............................60

2.3.2 Adaptation: Removal of potentially invasive plants ..........................................62

2.3.3 Adaptation: Increasing forest resistance and resilience in the face of pests and storms..................................................................62

2.3.4 Adaptation: Increasing 'general' forest ecosystem resistance and resilience ........63

$2.4 \quad$ Preparation and administration of the CE study......................................................65

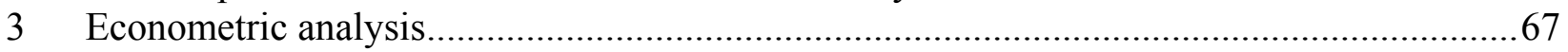

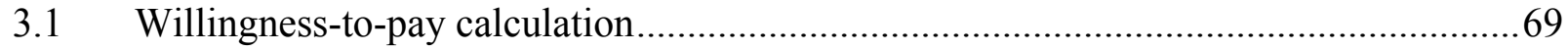

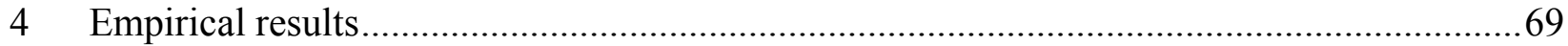

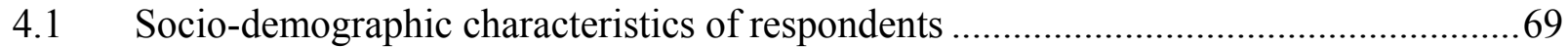

4.2 Importance of attributes for respondents........................................................ 70

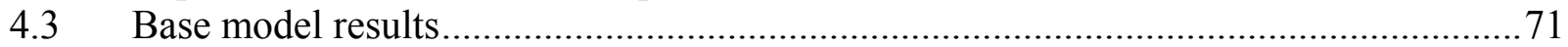

4.4 Model interactions: Influences of socio-demographic characteristics of respondents... 72

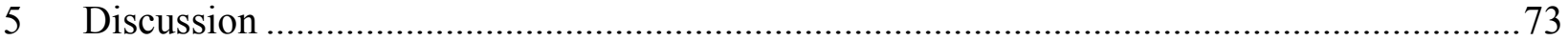

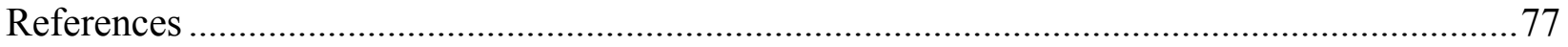

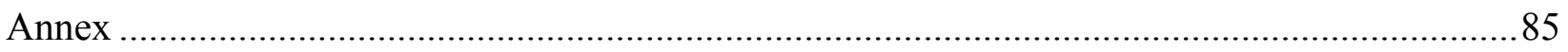

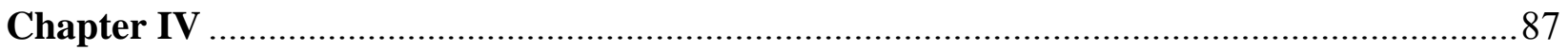

Pythias Rache: Zum Tauschwert ökologischer Versicherung vor unbekannten Risiken ......87

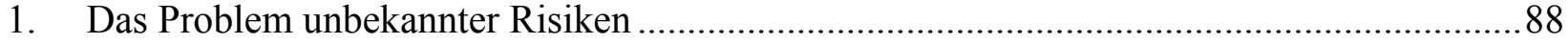

2. Strategien zum Schutz vor unbekannten Katastrophenrisiken .......................................92

3. Ökosystemare Versicherungsdienstleistungen im Bereich des Hainich Nationalparks.........94

3.1 Mykorrhiza-Diversität des Waldes als Vorsorge vor unbekannten Risiken ..................95

4. Ökonomische Quantifizierung von ökosystemaren Dienstleistungen?..............................97

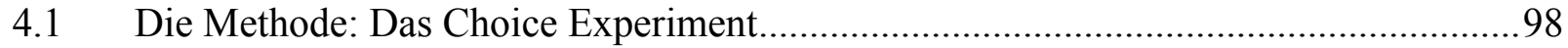

4.2 Erfassung der Risikowahrnehmung von Befragten.............................................99

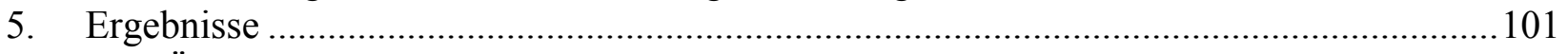

5.1 Ökonomische Risikobewertung ...................................................................... 101

5.2 Zahlungsbereitschaft für ein funktionierendes Waldökosystem als Vorsorge vor

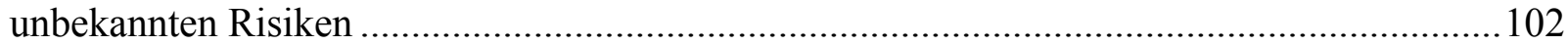

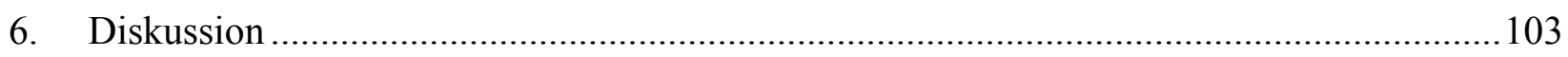

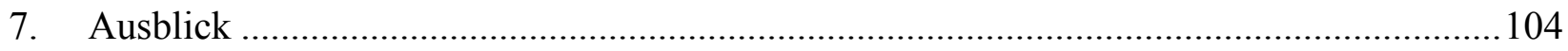

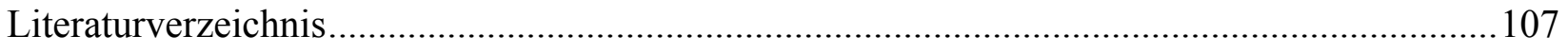


Chapter V

A cost-benefit analysis of controlling Giant Hogweeds (H. mantegazzianum) in Germany 111

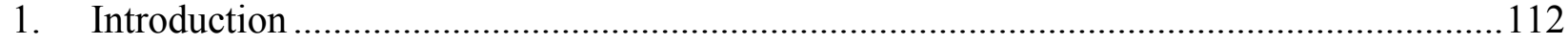

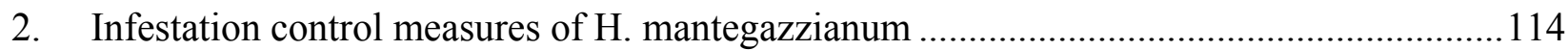

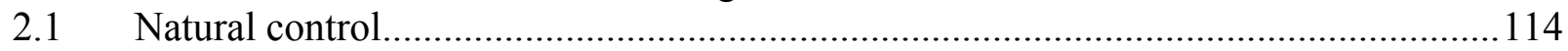

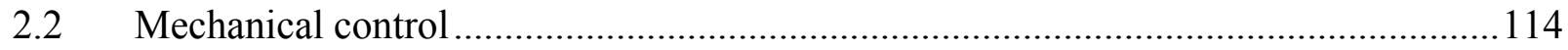

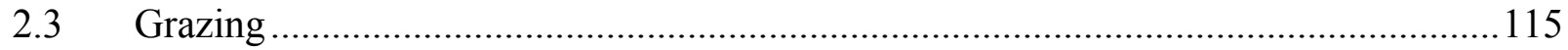

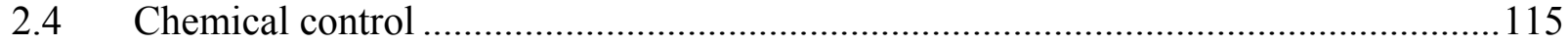

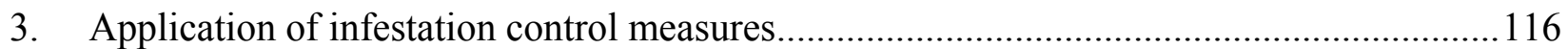

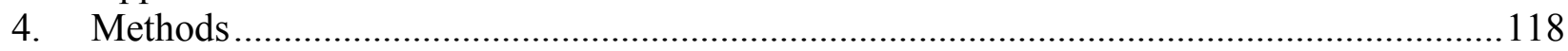

$4.1 \quad$ Cost-benefit analysis ........................................................................................118

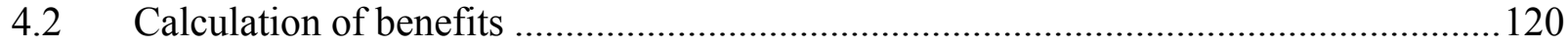

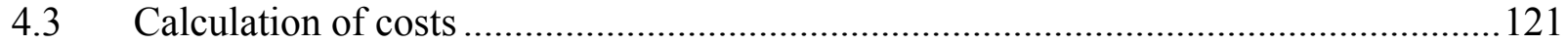

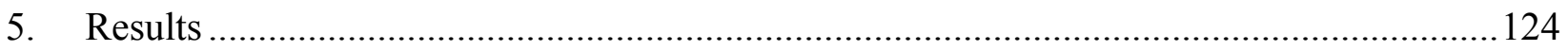

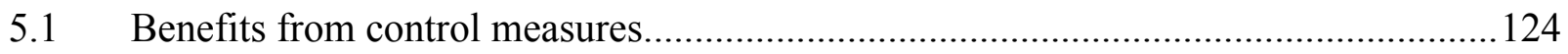

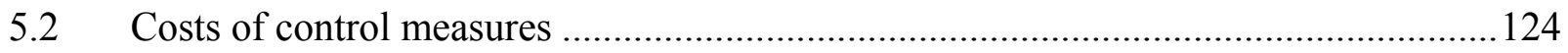

5.3 Benefit-cost relation of control measures...............................................................125

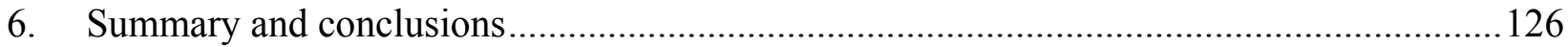

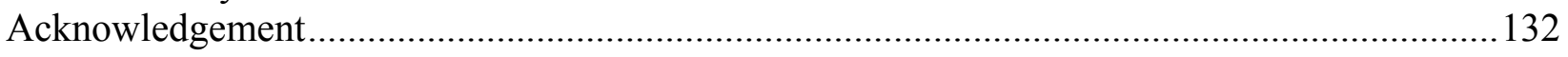

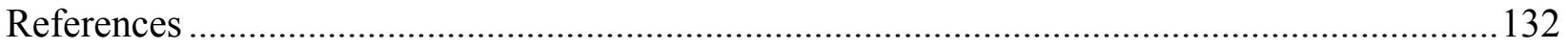

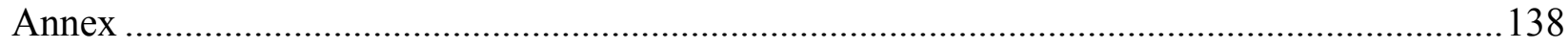

Appendix I: Questionnaire (German version) .......................................................................... 141

Appendix II: Example of a choice set (German version) ...........................................................149

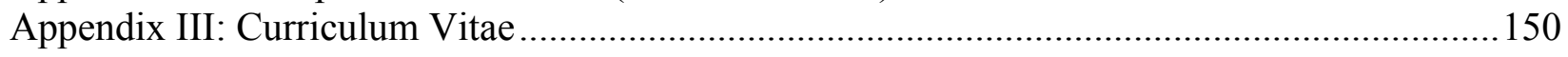




\section{Introduction}

\section{Background}

Because no market exists for most environmental goods and services, it is a challenge to estimate their economic benefits to society. Policy makers and stakeholders need such information on public preferences, e.g. in the face of climate change, to plan and implement environmental programs. Article 11 of the Convention on Biological Diversity (CBD; UNEP 2008a) requests every contracting party to establish incentives to conserve biodiversity and to guarantee its sustainable use and development. Human well-being and progress towards sustainable development are vitally dependent upon improving the management of Earth's ecosystems to ensure their sustainable use and the provision of ecosystem services (e.g. food supply, erosion control, maintenance of water and carbon cycles (UNEP 2003)). Humankind has transformed, isolated, fragmented or destroyed the world's landscapes and ecosystems (WBGU 1999). These impacts on our biosphere bear currently and increasingly in to the future imponderable risks including the risk of loss of chances and human well-being (WBGU 1999).

One strategy of future risk mitigation is to conserve functioning ecosystems as insurance in terms of a future source of ecosystem services including risk mitigation. Due to human dependency on these ecosystem insurance services, the ecological insurance towards risks or environmental changes (ecological insurance hypothesis; Yachi and Loreau 1999) also has an economic value (Perrings 1995). Is it possible to quantify this value? We show possibilities for the economic quantification of the ecological insurance value by means of a choice experiment (CE) for the valuation of biological diversity and ecosystem insurance services in the area of Hainich National Park (Thuringia, Germany). 


\section{Framework and objectives of the study}

This dissertation is sub-project C2 of the DFG-funded Research Training Group 1086 'The role of biodiversity for biogeochemical cycles and biotic interactions in temperate deciduous forests' coordinated by the Centre of Biodiversity Research and Ecology at Georg-August Universität Göttingen. The dissertation is integrated in the junior research group 'valuation of ecosystem functions and services' at the Department of Agricultural Economics and Rural Development, Georg-August-Universität Göttingen. Further research towards (i) the ecological insurance value concept and (ii) its potentially economic quantification was one aim of the overall DFG-project proposal (in 2005).

Previous empirical studies already indicated that a quantification of the ecological insurance value may be possible: two CE studies carried out in Chile (Cerda 2006) and in Indonesia (Witte 2005). In the first study (Cerda 2006) biodiversity was used as an indicator in terms of species numbers for a functioning ecosystem in contrast to other environmental values (aesthetic, cultural and existence value). The second study (Witte 2005) focused on a preservation of ecosystem health as ecological insurance by assuming the maintenance of current ecosystem health. In contrast to the previous studies, this dissertation focuses on the functional insurance value of forest-related diversity and its role for ecosystem insurance services towards known (e.g. climate change, invasive species) and yet unknown risks (classified as Pythia and Pandora risks by WBGU 1999). Additionally, extensive qualitative pre-studies on the functional insurance value of forest-related diversity were conducted for the first time.

Concrete overall objectives of the study are to investigate (a) how to apply the insurance value concept to a lay-person survey to investigate WTP, (b) if respondents are willing to pay for ecosystem insurance services in general, and (c) if so, to investigate the amount of WTP for ecosystem insurance services. Further objectives of the study are to identify (d) if risk perception 
of different kinds of 'certain' and 'uncertain' risks influence respondents' WTP for ecosystem insurance services. Another objective of the study is (e) the application of WTP values in further analysis to give suggestions for future policies (e.g. cost-benefit analysis).

To answer the first question (a), qualitative in-depth interviews were conducted $(\mathrm{n}=16)$; see first manuscript. To meet the requirements of the second and third question $(\mathrm{b} / \mathrm{c})$, a CE was carried out ( $\mathrm{n}=57$, pre-test; $\mathrm{n}=106$, pilot study; $\mathrm{n}=302$, main study); see manuscripts two to four. The question (d), if risk perception of different kinds of 'certain' and 'uncertain' risks influence respondents` WTP for ecosystem insurance services is answered in manuscript four. The application of WTP values in further analysis to give suggestions for future policies (e) is realised in manuscript five as a cost-benefit analysis.

\section{Detailed outline of the dissertation}

The promotion regulations of my $\mathrm{PhD}$ program require a statement on the authorship of the dissertation. I calculated all analyses on my own and wrote the first version of all manuscripts. I revised the manuscripts based on suggestions of and discussions with the co-authors and my supervisors respectively. This is an accumulative dissertation. Following the introduction, the dissertation is organized in five chapters or manuscripts.

The first manuscript, (Rajmis and Barkmann 2007) 'Utilisation of Grounded Theory Methodology for the development of a Choice Experiment: Preliminary studies on the insurance value of biodiversity' has been published as a book chapter in 'Stated Preference Methods for Environmental Valuation: Applications from Austria and Germany'. The importance of qualitative research for improving the design of stated preference survey instruments has been

emphasised for years (Arrow et al. 1993; Bateman et al. 2002; Mitchell and Carson 1989). The paper contributes to the discussion of the particular objective of the study: the ecological 
insurance hypothesis. The more unfamiliar the economic good to be valued is to survey respondents, the more important the qualitative preliminary studies are. Additionally, very little prior knowledge existed with respect to non-expert concepts of the elements of a semantic field revolving around uncertainty, risk, precaution, diversity and insurance. Thus, we selected a qualitative research methodology, the Grounded Theory Methodology (GTM; Strauss and Corbin 1996), which emphasises an inductive approach geared towards the understanding of respondent representations and valuations. Therefore, a qualitative preliminary study $(n=16)$ on respondent perceptions of different aspects related to the ecological insurance hypothesis was conducted. Insights from the qualitative research helped to design a $\mathrm{CE}$ instrument intended to be used for valuing the biological diversity of the Hainich forest (Thuringia). We discuss the advantages and disadvantages of using GTM for the qualitative phase of stated preference valuations studies of potentially unfamiliar environmental goods. Main objectives of the qualitative study are (i) identification of $\mathrm{CE}$ attributes and (ii) identification of attitudes respondents have towards the ecosystem insurance service background.

The second manuscript focuses on the core topic and main results of the study. 'The economic value of ecosystem insurance services of biodiversity towards known und unknown risks - a case study from the surrounding of Hainich National Park' (original title: "Der ökonomische Wert von Versicherungsdienstleistungen der Biodiversität gegen bekannte und unbekannte Risiken am Beispiel des Hainich National Parks") is published within a special edition of German Nature Conservation Agency and Ecological Society of Germany, Austria and Switzerland (Rajmis et al. 2008).

The third manuscript 'Forest-management measures to mitigate climate change or adapt to its effects: monetary preferences in the user community around Hainich National Park, Germany' has been accepted for publication in Climate Research. In this paper, the attribute topic 
'biodiversity as insurance towards changing climate' is emphasized. In contemporary media discourse, suggestions for publicly mandated climate change mitigation or adaptation measures are regularly challenged from a cost perspective. However, empirical data on the actual economic appreciation of local mitigation and adaptation measures expressed as citizen WTP are scarce. In this paper, we report results of a stated preference study using a CE that quantifies stated preferences for biodiversity-based climate change mitigation and adaptation management programs in the region surrounding Hainich National Park. This paper reports in some detail the work carried out in the field, background for econometric and statistical analysis and the interpretation of the results.

Besides the design of the CE to investigate WTP of respondents, additional items were designed that include a spectrum of risks from well-known environmental risks, such as pests and storms, to completely unknown risks. Results of respondents' rating towards these risks and their influence on WTP are reported in the fourth manuscript 'Pythias revenge or on the exchange value of ecological insurance against unknown risks'. This manuscript has been submitted to the Journal GAIA - Ecological Perspectives for Science and Society. The manuscript focuses on the following questions: (i) how did respondents perceive the displayed risks in terms of (un-) certainty of the risks? And, (ii) does this perception have any influence on preferences for attribute levels and WTP? 'Unknown risks' are dealt with in the main focus portion of this manuscript. Factor analysis and choice modelling analysis is followed by WTP calculations.

In the fifth manuscript the authors discuss 'A cost-benefit analysis of controlling Giant Hogweeds (H. mantegazzianum) in Germany' based on the CE attribute 'insurance services against invasive plants' (see Table 1). This manuscript will be submitted to the Journal of Environmental Management. The development of realistic control programmes under costbenefit aspects is one aim of the European Strategy on Invasive Alien Species (Genovesi and 
Shine 2003). With ratification of the Rio Declaration, Germany is committed to control any further spread of invasive species (UNEP 2008b). The paper analyses possible control options limiting stands of Giant Hogweeds (H. mantegazzianum) in Germany, focussing on cost-benefit aspects. Considering large spatial scales (Germany based on survey data of $n=287$ districts; Thiele and Otte 2008), we differentiate between several control options (e.g. root destruction, mechanical cutting or mowing, chemical treatment and grazing) depending on infested area size and protection status. The calculation of benefits is based on stated preference results $(\mathrm{CE} ; \mathrm{n}=$ 282). For the cost side, we calculate two different invasion scenarios (i) no re-infestation after successfully conducted control measures (optimistic) and (ii) re-infestation after conducting control measures occurring twice within ten years (pessimistic). For the cost-benefit analysis, we chose the measures with lowest costs for each area type. As sensitivity analysis we recommend to calculate switching values and overestimation factors indicating the reliability of hypothetical WTP results (compare Bräuer and Suhr 2005).

\section{The Choice Experiment Method (CE)}

The CE method was initially developed in marketing research to estimate economic preferences for characteristics (attributes) of new products. The CE method is based on the Characteristics Theory of Value (Lancaster 1966) and on Random Utility Theory (Adamowicz et al. 1998a, McFadden 1973). It has proven to be a versatile method for the estimation of economic values regarding the environment (Hensher et al. 2005). CEs rely on social science surveys for data gathering as does the related contingent valuation method. Instead of directly asking questions such as "Are you willing to pay $\mathrm{X} €$ to prevent $\mathrm{Y}$ effect of climate change?", CEs focus on tradeoffs among different policy scenarios with different environmental outcomes. 


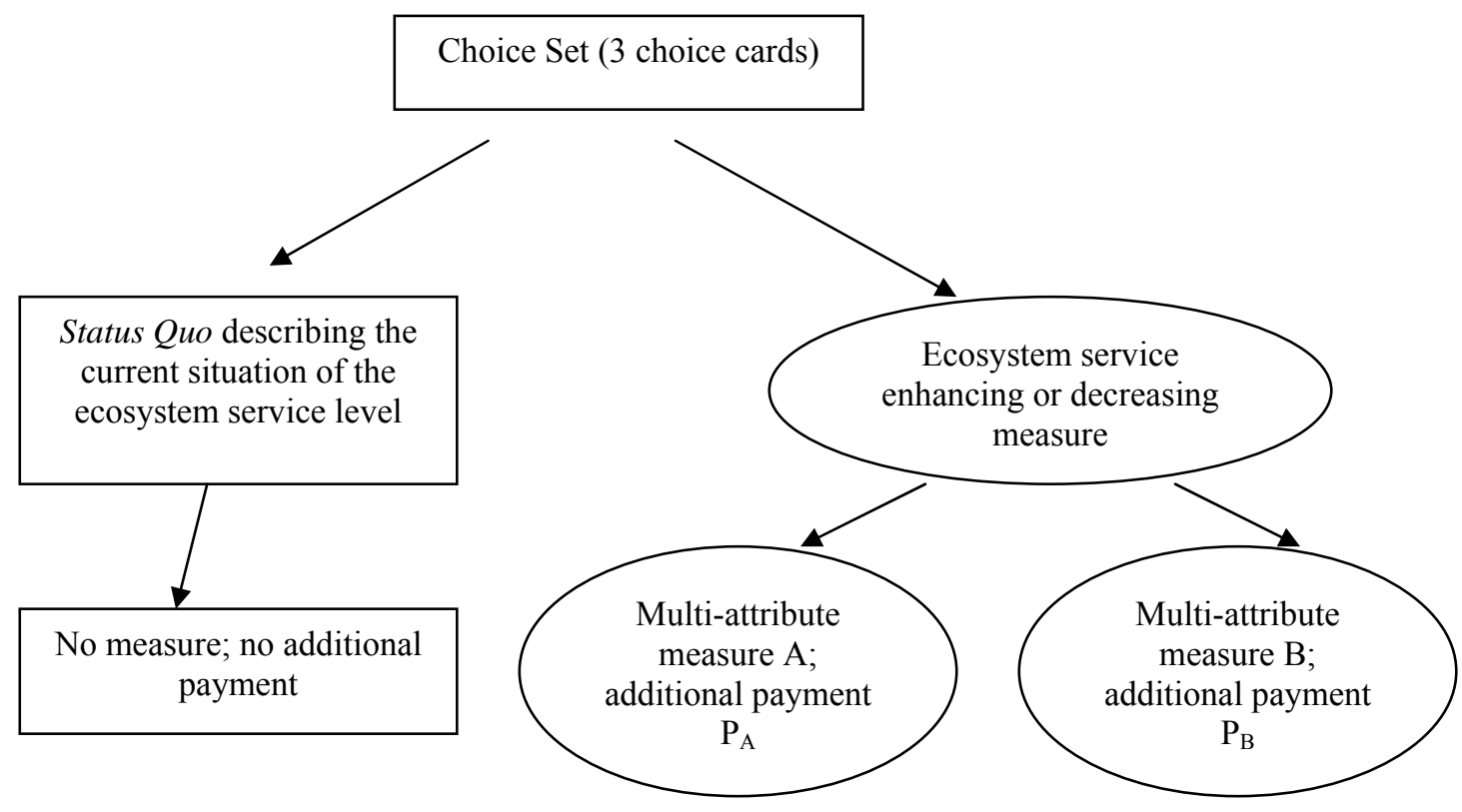

Figure 1. Structure of the Choice Experiment: a choice set with one status quo option and two multi-attribute ecosystem service measures generated by experimental design rules

The different choice scenarios ('options') of a CE differ in the levels that a small number of attributes (= characteristics) of the policy scenarios take. In CE face-to-face applications the scenarios are often printed on cardboard cards and presented to respondents. Respondents usually are confronted with three of these cards (the choice set), and asked to choose the policy scenario they want to see implemented. In our study two such cards characterise the generic policy options A and B, and a third card represents the current situation (Status Quo) (see Figure 1). The 'price' of each policy option is included as 'cost attribute' on the choice cards. The cost attribute is operationalized as a mandatory tax payment between 5 and $80 €$ per person and year. For the Status Quo card, the cost is zero. 
Table 1. Measures to preserve insurance services used in the Choice Experiment (translated from German questionnaire version)

\begin{tabular}{|c|c|c|c|c|}
\hline \multirow{2}{*}{$\begin{array}{l}\text { Attribute } \\
\text { Insurance services } \\
\text { against climate } \\
\text { change }\end{array}$} & \multirow{2}{*}{$\begin{array}{l}\text { Measure } \\
\text { Afforestation } \\
\text { quantified by carbon } \\
\text { sequestration equivalents }\end{array}$} & \multicolumn{3}{|c|}{$\begin{array}{l}\text { Level of measure } \\
\text { (Coding in parenthesis) }\end{array}$} \\
\hline & & $\begin{array}{l}\text { Sequestration } \\
\text { equivalents } \\
\text { of } 540 \text { persons } \\
(540)^{*}\end{array}$ & $\begin{array}{l}\text { Sequestration } \\
\text { equivalents } \\
\text { of } 630 \text { persons } \\
(630)\end{array}$ & $\begin{array}{l}\text { Sequestration } \\
\text { equivalents } \\
\text { of } 720 \text { persons } \\
(720)\end{array}$ \\
\hline $\begin{array}{l}\text { Insurance services } \\
\text { against invasive } \\
\text { plants }\end{array}$ & $\begin{array}{l}\text { Removal of non-native } \\
\text { plants (H. mantegazzianum) }\end{array}$ & $\begin{array}{l}\text { Only if harmful and } \\
\text { in particular cases } \\
(1)^{*}\end{array}$ & $\begin{array}{l}\text { Large scale removal } \\
\text { if harmful or not (2) }\end{array}$ & \\
\hline $\begin{array}{l}\text { Insurance services } \\
\text { against storms and } \\
\text { pests }\end{array}$ & $\begin{array}{l}\text { Planting of better site- } \\
\text { adapted tree species }\end{array}$ & $\begin{array}{l}\text { Low resistance and } \\
\text { resilience (1) }\end{array}$ & $\begin{array}{l}\text { Medium resistance } \\
\text { and resilience }(2)^{*}\end{array}$ & $\begin{array}{l}\text { High resistance } \\
\text { and resilience (3) }\end{array}$ \\
\hline $\begin{array}{l}\text { Insurance services } \\
\text { against unknown } \\
\text { risks/general forest } \\
\text { ecosystem resilience }\end{array}$ & $\begin{array}{l}\text { Changes in the diversity of } \\
\text { mycorrhizal fungi }\end{array}$ & $\begin{array}{l}\text { Low resistance and } \\
\text { resilience (1) }\end{array}$ & $\begin{array}{l}\text { Medium resistance } \\
\text { and resilience } \\
(2)^{*}\end{array}$ & $\begin{array}{l}\text { High resistance } \\
\text { and resilience (3) }\end{array}$ \\
\hline Cost attribute & $\begin{array}{l}\text { Mandatory tax payment per } \\
\text { person and year }\end{array}$ & $0 €^{*}, 5 €, 10 €, 20$ & $5 €, 50 €, 60 €, 80 €$ & \\
\hline
\end{tabular}

*attribute level indicating the status quo of the particular insurance service.

\section{The study region}

As this dissertation is sub-project C2 of the DFG funded Research Training Group 1086, the described hypothetical conservation measures refer to the Hainich forest and Hainich National Park (NP) area. Hainich NP has around 7,600 ha and the whole Hainich forest about 16,000 ha. It is the largest coherent deciduous forest in Germany. The forest is dominated by Fagus sylvatica L. (European Beech), mostly uneven-aged, and has not been harvested, thinned or used at least since 1997 (Mund 2004; Mölder et al. 2006). During the previous 32 years (since 1964) the forest was used for military training. During this time, only a few single trees of high value were cut (Mund 2004). At present, 90\% of the Hainich NP is not being used for forestry or any other cultivation (Hainich National Park Administration Department 2008a). 


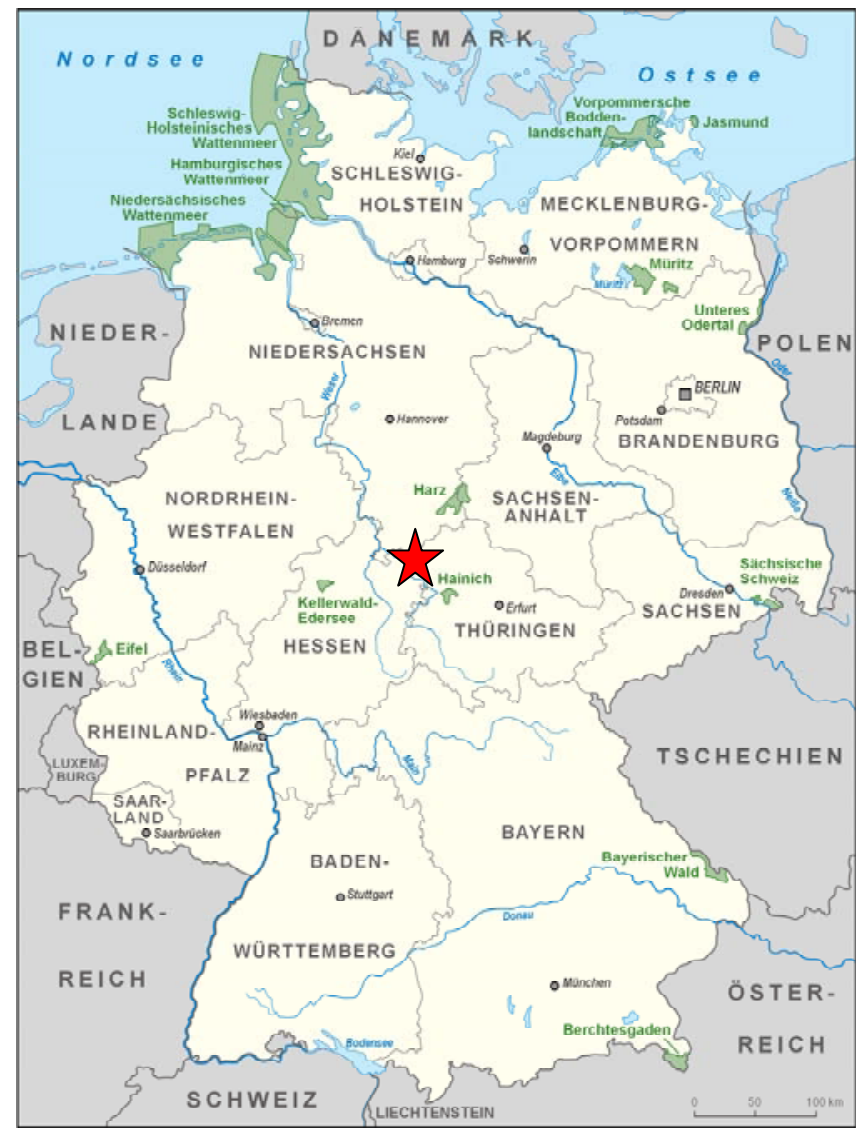

Figure 2. Location of Hainich National Park (Thuringia, Germany); $10^{\circ} 27^{\prime} 45^{\prime \prime} \mathrm{E}, 51^{\circ} 4^{\prime} 48^{\prime \prime} \mathrm{N}$ source: Hainich National Park Administration Department (2008b)

\section{Preparation and administration of the CE study}

From the attributes and attribute levels (Table 1), an orthogonal main effects design (Hensher et al. 2005:115, Chrzan and Orme 2000) was generated with 64 combinations of different choice cards that were assigned to four blocks of eight choice sets. Each respondent was randomly assigned to one of four blocks.

The CE main survey $(\mathrm{n}=302)$ was preceded by qualitative preliminary studies $(\mathrm{n}=16)$, pre-test interviews $(\mathrm{n}=57)$, and a pilot study $(\mathrm{n}=106)$. Pilot study and main study were conducted as a household survey using face-to-face interviews in 19 of the about 30 villages adjacent to Hainich National Park, and in the neighbouring towns of Eisenach and Bad 
Langensalza (federal state of Thuringia, central Germany). To sample private households, the random route method (Kromrey 2006) was used. Target respondents were all German speaking individuals who were at least 18 years of age by the day of the interview. Target persons were identified by the 'last-birthday' method, which means that the person with the most recent birthday was sampled (Rizzo et al. 2004). All interviews (pilot and main study) were conducted by five well-trained university students. An average interview took 35 minutes.

471 contacted target respondents denied giving an interview. Of the successfully contacted 302 households, 282 respondents completed the choice task. 20 respondents $(6.62 \%)$ protested to the CE (see Adamowicz et al. 1998b). Eleven of these protested against the cost attribute (rejection of any extra tax, extremely sceptical attitude towards implementation of the proposed measures). Furthermore, three protesters refused any measure ('no human impact towards nature') involving Hainich National Park, while another two respondents had a strict noninterference attitude towards the National Park. Only two respondents directly opposed the proposed measures (attributes). Finally, two individuals did not understand the choice task.

\section{Fundamental results}

The gender distribution of respondents is well-balanced ( $49 \%$ women). The youngest respondent was 18 years old, the oldest 92 . The majority of respondents (45\%) holds a secondary school degree and is salaried (47\%). Average net-income is 1,125 €. The socio-demographic results point at a reliable statistical design and respondent selection because values are close to national averages (Statistisches Bundesamt 2008). 86\% of respondents have been to Hainich National Park at least once. On average, respondents visit Hainich National Park 14 times per year.

Overall the choice model (Nested Logit) is most highly significant $\left(\mathrm{P}_{\mathrm{Chi}^{2}}<0.0001\right)$. All attributes are significant determinants of choice (ecosystem insurance services against climate 
change, storms and pests and unknown risks at $\mathrm{p}<0.001$ and insurance services against invasive plants at $\mathrm{p}<0.05)$. Statistically significant attribute coefficients in the models allow for the calculation of WTP for attribute level changes. Maximum WTP for a one level change of a single attribute is calculated as marginal WTP (mWTP). Including protest responses (6.62\% of respondents) as ' 0 ' $€ \mathrm{mWTP}$, slightly lower $\mathrm{mWTP}$ values are obtained. In the following, corrected mWTP values are shown in parenthesis. With respect to the range of the proposed attribute levels, the most important attribute is the 'ecosystem insurance services against storms and pests', it has the highest attribute coefficient (coefficient value is 0.455 and mWTP is $27.54 €$ $(25.71 €)$. As the attribute was coded linearly from 'low resistance and resilience' (Level 1) up to 'high resistance and resilience' (Level 3), the coefficient sign implies that respondents prefer 'high resistance and resilience' (see Table 1). The second strongest attribute is the 'insurance services against climate change'. As attribute levels were coded with 'carbon sequestration equivalents' as shown in Table 1, the attribute sign implies that respondents prefer higher levels of carbon sequestration equivalents (coefficient value is 0.354 ; mWTP is $21.43 €(20.01 €)$. The third strongest attribute is the 'ecosystem insurance services against unknown risks' with a mWTP of $16.83 €(15.71 €$; coefficient value is 0.278$)$. Respondents prefer 'high resistance and resilience'. This attribute is followed by 'ecosystem insurance services against invasive species'. For the moderate control of obviously dangerous plants such as $H$. mantegazzianum respondents are willing-to-pay $9.59 €(8.96 €)$ per person and year when compared to more aggressive removal schemes (coefficient value is -0.158 ).

Taking mWTP values corrected for protest responses into account, a shadow price for C sequestration related to personal emissions can be calculated. Based on the mWTP value for one level change of $20.01 € \mathrm{a}^{-1}$ per $\sim 2.7 \mathrm{tC}$ emissions $\mathrm{a}^{-1}$, a shadow price of $7.34 € \mathrm{t}^{-1} \mathrm{a}^{-1}$ can be calculated. 


\section{Discussion of main research objectives and questions}

Qualitative in-depth interviews (preliminary study) as well as the CE study were conducted successfully (objective a; see chapter one). The preliminary study (i) supported attribute design based on declarative respondent knowledge about ecological risks, (ii) elucidated the general background of the construction of the $\mathrm{CE}$ instrument, (iii) helped in solving a few specific wording issues. Additionally, (iv) it allowed for a justification of the attempt to quantify preferences for a highly unfamiliar ecosystem service. The identified risks (non-native species, risks posed by diseases, pests and storms to the forest ecosystem, and risks by climate change) were directly used for attribute development of the CE.

The $\mathrm{CE}$ revealed that respondents are willing-to-pay between (-)8.96€ and $25.72 €$ for ecosystem insurance services (objective b and c; see chapter two to four). With a successful implementation of the CE study, there is empirical evidence for the quantification of ecosystem insurance services against unknown and the described known risks.

The self-designed items to measure risk perception of respondents (objective d; see chapter four) (i) come out as a meaningful instrument to identify perception of respondents towards risks, and (ii) to determine influence of risk perception on attribute level choice and WTP. Risk perception was measured in the frame of an item set ranging from 'likely' to 'completely uncertain/unlikely' environmental risks. Results indicate that risk perception has a positive influence on WTP and preferences for higher resilience level of forest biodiversity-based insurance services. In other words, the more likely respondents perceive the occurrence of the described risks, the higher is their WTP for ecosystem insurance services.

The application of WTP values in further analysis to give suggestions for future policies (objective d) is realised in chapter five. The cost-benefit analysis of Giant Hogweed control ( $H$. mantegazzianum) identifies overall costs of $6,498,036 €$ for the optimistic invasion scenario and 
$11,280,621 €$ for the pessimistic scenario. Overall benefits result in $238,063,641 €$ (one single payment). The average benefit-cost relation of German districts for control measures of $H$. mantegazzianum is $37: 1$ for the optimistic scenario and 21:1 for the pessimistic scenario calculations for infested areas ranging between $100 \mathrm{~m}^{2}$ and $10,000 \mathrm{~m}^{2}$. Results indicate that every euro of calculated costs can be opposed to an average of $29 €$ in benefits. The calculated benefitcost values are larger than one indicating that advantages of the project prevail (Marggraf 2005, Gans and Marggraf 1997). If our empirically investigated WTP results for control measures

would be overestimated by factors between 180 (pessimistic scenario), and 300 (optimistic scenario) 'necessary' real WTP would be still the amount of the switching values $(0.05 €$ and $0.03 €)$, hence high enough to keep the benefit-cost relation positive. Results of overestimation calculation might be seen as an indicator for the reliability of the empirical study.

\section{References}

Adamowicz W, Louviere J, Swait J (1998a) Introduction to Attribute-Based Stated Choice Methods. Advanis Inc. for the National Oceanic and Atmospheric Administration, US Departement of Commerce

Adamowicz W, Boxall P, Williams M, Louviere J (1998b) Stated preference approaches to measuring passive use values. American Journal of Agricultural Economics 80: 64-75

Arrow K, Solow R, Portney PR, Learner EE, Radner R, Schuman H (1993) Report of the NOAA Panel on Contingent Valuation. Resources for the Future, Washington D.C.

Bateman IJ, Carson RT, Day B, Hanemann M, Hanley N, Hett T, Jones-Lee M, Loomes G, Mourato S, Özdemiroglu E, Pearce OBE DW, Sugden R, Swanson J (2002) Economic valuation with Stated Preference Techniques: A manual. Edward Elgar, Cheltenham, Northhampton

Bräuer I, Suhr A (2005) Ergebnisse von Zahlungsbereitschaftsanalysen: Interpretation und Verwendung. In: Marggraf R, Bräuer I, Fischer A, Menzel S, Stratmann U, Suhr A (eds.) Ökonomische Bewertung bei umweltrelevanten Entscheidungen. Metropolis, Marburg, p 
$149-183$

Cerda C (2006) Valuing biological diversity in Navarino Island, Cape Horn Archipelago, Chile: a choice experiment approach. $\mathrm{PhD}$ dissertation, Georg-August-Universität Göttingen, Germany

Chrzan K, Orme B (2000) An Overview and Comparison of Design Strategies for Choice-Based Conjoint Analysis. Sawtooth Software 2000-2002. Research paper series.

Gans O, Marggraf R (1997) Kosten-Nutzen-Analyse und ökonomische Politikbewertung. Springer, Berlin, Heidelberg

Genovesi P, Shine C (2003) European Strategy on Invasive Alien Species. Convention on the conservation of European wildlife and natural habitats. Council of Europe Publishing, Strasbourg

Hainich National Park Administration Department (2008a) Wissenswertes über den Nationalpark Hainich. Accessed 15 Feb. 08 www.nationalpark-hainich.de/verstehen/wissenswertes.html Hainich National Park Administration Department (2008b) Map obtained by request Hensher D, Rose J, Greene W (2005) Applied choice analysis: a primer. Cambridge University Press, Cambridge

Kromrey H (2006) Empirische Sozialforschung. Modelle und Methoden der standardisierten Datenerhebung und Auswertung. Lucius \& Lucius, Stuttgart

Lancaster K (1966) A New Approach to Consumer Theory. Journal of Political Economy 74:132157

Marggraf R (2005) Ökonomische Grundlagen der Umweltbewertung. In: Marggraf R, Bräuer I,

Fischer A, Menzel S, Stratmann U, Suhr A (eds), Ökonomische Bewertung bei umweltrelevanten Entscheidungen. Metropolis, Marburg p 61-83

McFadden D (1973) Conditional Logit Analysis of Qualitative Choice Behavior. In: Zarembka P (ed) Frontiers in Econometrics. Academic Press, New York p 105-142

Mitchell RC, Carson RT (1989) Using Surveys to value public goods: The Contingent Valuation Method. Resources for the Future, Washington D.C.

Mund M (2004) Carbon pools of European beech forests (Fagus sylvatica) under different silvicultural management. $\mathrm{PhD}$ dissertation, Georg-August-Universität Göttingen, Germany Mölder A, Bernhardt-Römermann M, Schmidt W (2006) Forest ecosystem research in Hainich National Park (Thuringia): First results on flora and vegetation in stands with contrasting 
tree species diversity. Waldökologie online 3:83-99

Perrings C (1995) Biodiversity conservation as insurance. In: Swanson TM (ed) The economics and ecology of biodiversity decline: The forces driving global change. Cambridge University Press, Cambridge, New York, Melbourne p 69-77

Rajmis S, Barkmann J (2007) Utilisation of Grounded Theory Methodology for the development of a choice experiment: Preliminary studies on the insurance value of biodiversity. In: Meyerhoff J, Lienhoop N, Elsasser P (eds) Stated Preference Methods for Environmental Valuation: Applications from Austria and Germany. Metropolis, Marburg p 175-202 Rajmis S, Barkmann J, Marggraf R (2008) Der ökonomische Wert von Versicherungsdienstleistungen der Biodiversität gegen bekannte und unbekannte Risiken am Beispiel des Hainich National Parks (Thüringen). In: Bundesamt für Naturschutz (ed) Naturschutz und Biologische Vielfalt. Bonn, p 207-212

Rizzo L, Brick JM, Park I (2004) A Minimally Intrusive Method for Sampling Persons in Random Digit Dial Surveys. Public Opinion Quarterly 68:267-274

Statistisches Bundesamt (2008) Bevölkerung Deutschlands bis 2007. 11. Koordinierte Bevölkerungsvorausberechnung. Accessed 12 June 07 www-c.destatis.de/csp/ shop/sfg/bpm.html.cms.cBroker.cls?cmspath=struktur,vollanzeige.csp\&ID=1019439

Strauss A, Corbin J (1996) Grounded Theory: Grundlagen Qualitativer Sozialforschung. Beltz, Weinheim

Thiele J, Otte A (2008) Invasion patterns of Heracleum mantegazzianum in Germany on the regional and landscape scales. Journal for Nature Conservation 16:61-71

UNEP [United Nations Environment Programme] (2003) Millennium Ecosystem Assessment: Ecosystems and Human Well-being. Island Press, Washington, Covelo, London UNEP [United Nations Environmental Program] (2008a) Article 11. Incentive measures. Convention on Biological Diversity (CBD) Accessed 20 June 08 www.cbd.int/convention/articles.shtml? $\mathrm{a}=\mathrm{cbd}-11$

UNEP [United Nations Environmental Program] (2008b) Invasive Alien Species. Convention on Biological Diversity (CBD). Accessed 19 June 08 www.cbd.int/invasive WBGU [Wissenschaftlicher Beirat der Bundesregierung Globale Umweltveränderungen] (1999). Jahresgutachten 1998: Strategien zur Bewältigung Globaler Umweltrisiken. Springer, Berlin, Heidelberg (available in English)

Witte JP (2005) Determination of willingness to pay for "Ecosystem Health" in terms of 
prevention of unknown environmental dangers in Central Sulawesi (Indonesia): a choice experiment approach. Diploma Thesis at the Department of Geography, Georg-AugustUniversität Göttingen, Germany

Yachi S, Loreau M (1999) Biodiversity and ecosystem productivity in a fluctuating environment: the insurance hypothesis. Proceedings of the National Academy of Sciences of the U.S.A. $96: 1463-1468$ 


\section{Chapter I}

\section{Utilisation of Grounded Theory Methodology for the development of a Choice Experiment: Preliminary studies on the insurance value of biodiversity*}

Sandra Rajmis and Jan Barkmann

Abstract: Based on the ecological insurance hypothesis, ecologists and environmental economists stress the importance of biological diversity for maintaining ecosystem resilience. We conducted extensive qualitative preliminary studies on respondent perceptions of different aspects related to the ecological insurance hypothesis using the Grounded Theory Methodology (GTM). Insights from the qualitative research helped to design a Choice Experiment (CE) instrument intended to be used for valuing the biological diversity of the Hainich forest (Thuringia), the largest coherent deciduous forest in Germany. We discuss the advantages and disadvantages of using GTM for the qualitative phase of stated preference valuation studies of potentially unfamiliar environmental goods.

Keywords: Grounded Theory Methodology, insurance services of biodiversity, perception of biodiversity and ecosystem functioning

* A similar version of the manuscript was published as book chapter in 'Stated Preference Methods for Environmental Valuation: Applications from Austria and Germany’ (see Rajmis and Barkmann 2007) 


\section{Introduction}

Based on the results of biodiversity research and ecosystem theory, we investigate the willingness to pay (WTP) for additional measures for the protection of ecosystem insurance services. In line with the long-term, generation-spanning perspective of sustainable development (WCED 1987, 43; UNEP 1992), § 1 of the German Federal Nature Protection Act stresses the importance of securing the fundamental functional capacity of ecological systems. This functional capacity does not only provide the "ecosystem fabric" (Turner 2001) for known ecosystem services. It also provides insurance against unspecific ('unknown') risks to the human-environment-relation.

Biodiversity is an essential component of ecological self-organisation (Kutsch et al. 2001; Barkmann \& Marggraf 2004), which is itself a dynamic expression of the functional capacity of ecological systems that ensures ecosystem resilience (Yachi and Loreau 1999; McCann 2000; Loreau et al. 2001, 2003). To the extent that ecosystem resilience translates into stabilising the services that humans obtain from the environment, biodiversity possesses an economic insurance value (Perrings 1991, 1995; Turner 2001). These insurance benefits include insurance against unknown risks to the human-environment-relation (Barkmann \& Marggraf 2004). A collaborative research project on the functional importance of tree species diversity in Central European beech forests conducted at Hainich National Park (Thuringia, Germany; see Schmidt et a. 2006), provided a framework for a valuation study on the insurance services of biological diversity.

Can such insurance benefits, which are highly unfamiliar to average survey respondents, be valued in monetary terms; in particular, can they be assessed using stated preference techniques such as CEs? Turner (2001) argues that fundamental ecosystem functioning is a primary value beyond the conventional Total Economic Value framework. In this contribution we argue that it is possible to obtain meaningful valuation statements when extensive 
Chapter I

qualitative preliminary studies are undertaken. In this case, GTM is applied - similar to the focus group method, which is used quite frequently in other valuation studies - to develop a $\mathrm{CE}$ questionnaire using qualitative in-depth information. Given the unspecific character of unknown risks and the low familiarity of non-expert respondents with the ecological insurance hypothesis, in-depth investigations into respondent perceptions and values relevant to ecosystem insurance services are called for. In our preliminary studies

(i) GTM provided insights into the general patterns of the description and appreciation of biodiversity

(ii) identified risk perception of respondents by means of the analysis-tools (called "coding") of the applied methodology (see Section 2.1), which were concretely used for the $\mathrm{CE}$ attributes (see Section 4.2) to represent possible and simultaneously well-known threats for the ecosystem services of the Hainich National Park, and

(iii) pointed at commonly held images of nature and attitudes on the human-naturerelation (see Section 4.2).

The valuation of insurance services against highly unspecific or even completely unknown risks to the human-environment relation poses a second conceptual and pragmatic challenge: If the risks are unknown by definition, how can the value of insurance against them be quantified in economic terms? Yet, unknown risks are perceived as particularly threatening by individuals (Jungermann and Slovic 1993), respective risk mitigation strategies have been outlined (WGBU 1999) - and are implemented in areas such as genetic engineering laboratories (Gill 1998). If possible, a welfare economic quantification of citizen preferences for such insurance services would substantially contribute to the discussion of the political and administrative implementation of the precautionary principle in fields such as nature 
conservation and spatial planning. Thus, we review the conceptual foundation of the insurance value of biological diversity in some more depth in Section 3.

In Section 4, the application of the qualitative research methodology to a case study on forest development options in and around Hainich National Park is described ${ }^{1}$. The material presented focuses on selecting adequate information for the respondents. This is necessary in order to avoid information-related biases in the design of a Choice Experiment instrument.

\section{Improving stated preference survey instruments using qualitative}

\section{research}

The importance of qualitative research for improving the design of stated preference survey instruments has been emphasised for years (Arrow et al. 1993; Bateman et al. 2002; Mitchell and Carson 1989). The more unfamiliar the economic good to be valued is to survey respondents, the more important are qualitative preliminary studies. Additionally, very little was known beforehand about non-expert concepts of the elements of a semantic field revolving around uncertainty, risk, precaution, diversity and insurance. Thus, we selected a qualitative research methodology, the Grounded Theory Methodology (GTM), which emphasises an inductive approach geared towards the understanding of respondent representations and valuations. After a brief introduction of GTM strategies, we outline central steps of the methodology, and discuss results from the analysis.

\subsection{Strategies of Grounded Theory Methodology (GTM): Analytic tools}

"Grounded Theory" means theory that is derived from data, systematically gathered and analysed through the research process. While we do not aim to generate theory, the main emphasis in this study was placed on the precise analysis instruments that "Grounded Theory"

\footnotetext{
${ }^{1}$ The questionnaire used in our quantitative study is available upon request.
} 


\section{Chapter I}

offers. GTM provides insights, enhances understanding, and provides a meaningful guide to action due to its close relationship between data and the analysis process. In other words, GTM is a qualitative research approach which aims at iteratively elaborating (theoretical) statements about social phenomena. In the present case, the phenomena to be scrutinised are the perceptions of the insurance function of biodiversity which exist within society. During the analysis of these perceptions, continuous reference is made to the empirical data (here: results of interviews about individual perceptions). ${ }^{2}$ This is done by applying different techniques of data analysis, called "coding strategies" (open, axial and selective coding) which are used in a stepwise manner (Strauss and Corbin 1998).

Generally, results from open, axial and selective coding have different levels of abstraction $^{3}$. Open coding breaks a text into different segments. Thus, the generated codes are identified segments of the text that can be further categorised (Strauss and Corbin 1996). The second step in the coding process is axial coding (Strauss and Corbin 1996, 75). Several codes may have the same "background" emerging through further text inspection. This leads to categories. Categories and in-vivo codes are generated from codes of the open coding. Axial coding continues by developing central ideas or a central phenomenon as a refinement and differentiation of existing categories. Axes reflect feasible empirical relations between categories. Axial coding is followed by selective coding (Strauss and Corbin 1996, 94). By condensation of categories and axes, results are further elaborated and validated. Selective coding identifies the central analytical idea(s)/phenomena, under which all categories and axes can be subsumed. Ideally, the process culminates in devising a theory of the central phenomenon. The different coding strategies are displayed in Table 1 by means of some

\footnotetext{
2 The term "grounded" refers to grounded in the data and in empiricism.

${ }^{3}$ Exceptions are in-vivo codes. An in-vivo code is a particularly illuminating text segment that has such a strong expression in the original wording that it stands simultaneously for concrete and more abstract categories, and even axes.
} 


\section{Chapter I}

examples for the open, axial and selective coding. Table 1 displays exemplary original text extracts (translated and transcribed from the original interviews in German) from Interviews 6, 3 and 15 (rows 2,63 and 2/3) and their analysis by the above described coding techniques of the applied methodology. Following the columns (from the left to the right side) from the original interview text extracts via the open code to the axial and selective code, different levels of abstraction become apparent (e.g. "situation in New Orleans" (original text: Int. 15, row $2 / 3$ ) to "fear of forces of nature". Insights gained at a higher level of abstraction can result in a reclassification down the hierarchy. Thus, coding can start at any part, for example, of an interview transcript. It is even possible to code just some sentences or one paragraph of the transcript. In our case study (see Section 4) the transcripts of sixteen semi-structured interviews were coded.

Table 1: Examples for the coding strategies

\begin{tabular}{|c|c|c|c|}
\hline Original text & Open code & Axial code & Selective code \\
\hline $\begin{array}{l}\text { Row 2, Interview } 06 \\
\text { Due to all the things in former } \\
\text { times, [...] such as meteor impacts } \\
\text { or fires, nature has over and over } \\
\text { succeeded to get something going }\end{array}$ & $\begin{array}{l}\text { Nature has over } \\
\text { and over succeeded } \\
\text { to get something } \\
\text { going }\end{array}$ & $\begin{array}{l}\text { Nature succeeds } \\
\text { time and again }\end{array}$ & $\begin{array}{l}\text { Existence of nature } \\
\text { as evidence for its } \\
\text { robustness (2) }\end{array}$ \\
\hline $\begin{array}{l}\text { Row } 63 \text {, Interview } 03 \\
\text { Diverse species may also include } \\
\text { some species that win the upper } \\
\text { hand }[\ldots] \text {. Some species can get } \\
\text { lost and some, that are resistant, } \\
\text { win the upper hand }\end{array}$ & $\begin{array}{l}\text { In the end nature } \\
\text { wins the upper } \\
\text { hand, resistant } \\
\text { species win the } \\
\text { upper hand }\end{array}$ & $\begin{array}{l}\text { Vigour of nature, } \\
\text { vigour of species }\end{array}$ & $\begin{array}{l}\text { Vigour of nature } \\
\text { (1) }\end{array}$ \\
\hline $\begin{array}{l}\text { Row } 2 / 3 \text {, Interview } 15 \\
\text { If we look at the situation in New } \\
\text { Orleans at the moment, we have to } \\
\text { realize that we can't restrain forces } \\
\text { of nature }\end{array}$ & $\begin{array}{l}\text { We can't restrain } \\
\text { forces of nature }\end{array}$ & $\begin{array}{l}\text { Perception that } \\
\text { humans can't } \\
\text { restrain forces of } \\
\text { nature and thus are } \\
\text { afraid of this threat }\end{array}$ & $\begin{array}{l}\text { Fear of forces of } \\
\text { nature (4) }\end{array}$ \\
\hline
\end{tabular}

Regarding the economic valuation of insurance services of biodiversity, we were faced with a situation for which the GTM is well suited: (i) We had to generate an understanding about how respondents perceive insurance services in an inductive way, because the scientific 
knowledgebase was insufficient for the deduction of sufficiently rich a priori hypotheses, and (ii) the complex concept of protection against highly uncertain risks is almost exclusively language mediated. Any choice behaviour observed in the CE survey is likely to be influenced by the text (e.g. the written and spoken information) used in communication with respondents. Accordingly we used the coding strategies for discovering and describing categories of the pre-known phenomenon in a generalised way. GTM analysis was conducted to make a profound analysis of the phenomenon "insurance value and insurance services of biodiversity and forest diversity". "Images and attitudes towards nature" reflecting the

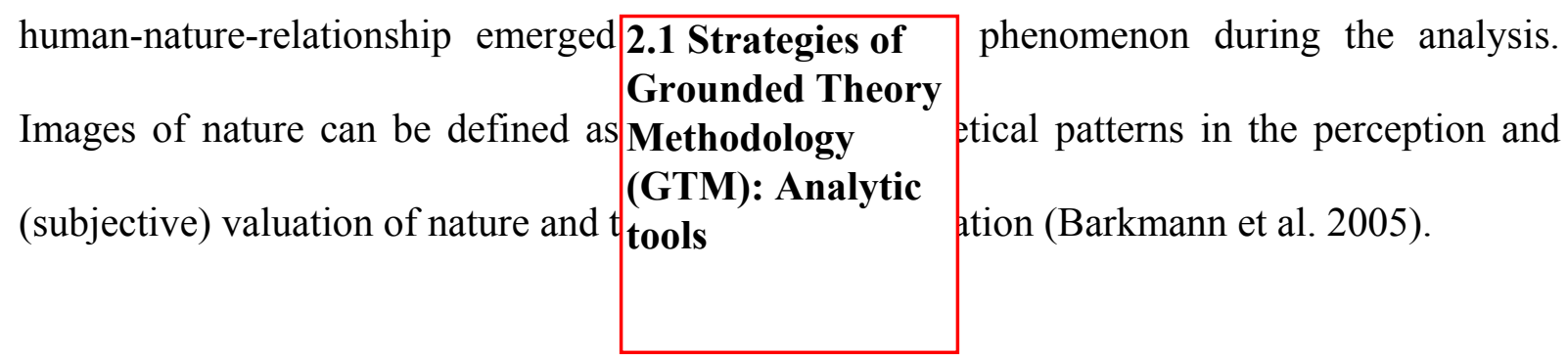

\subsection{Advantages and disadvantages of GTM}

While we discuss specific advantages and disadvantages of using GTM that became evident during the case study in the conclusion (Section 5), some more general considerations are presented here. In particular, we focus on the combination of individual in-depth interviews guided by GTM in comparison to focus groups (Agar and MacDonalds 1995), a method frequently used in the preliminary studies phase of stated preference studies. The main characteristic of focus groups is a guided group discussion of selected participants on issues introduced by the analyst (Bryman 2004). This characteristic is not necessarily a definite difference between both methods, however, because transcripts or video recordings of focus group discussions can be analysed by GTM coding strategies. Used alone, focus groups differ from GTM guided preliminary studies mainly by the more comprehensive approach of GTM aiming at understanding of even highly complex social contexts.

Focus group data analysis and GTM analysis have in common that both intend to report 


\section{Chapter I}

the views of participants, try to avoid generalisations to larger groups, aim at the elucidation of why subjects think or act in a certain way rather than how many. In both methods, the analyst is instructed to look for patterns of findings, consider the choice and meaning of words, and consider the context of a statement (Bogdan and Biklin 1998). Both methods are used in valuation studies to guide questionnaire design (e.g. Liebe and Meyerhoff 2007, Agar and MacDonalds 1995, Böhm 2004).

Beyond this, application and analysis of focus groups does not need detailed methodological prescriptions of how meaning is extracted from participant expressions in rather familiar or less complex situations. This manifests itself in the widely used adoption of original quotes in a "summary report" as a result of data analysis (e.g. Puchta and Wolff 2004). Most tellingly, less complex situations can also be approached with concrete coding categories for the analysis of focus group data that were prefabricated even before starting data analysis. In their qualitative methods textbook, Bogdan and Biklin (1998), provide such categories for focus groups applied in educational studies. In contrast, Glaser and Strauss $(1998,108)$ stress the generation of explicit coding during the analytic process.

Either because of its more liberal approach, in terms of analytical methodology, or because of the opportunity to use pre-fabricated codes, focus group data analysis can move comparatively fast from original data to conclusions. In contrast, the coding process of GTM is relatively time-consuming as it obligatorily requires an intensive analysis of the text material. Without adequate computer-aided coding support (e.g. by MAXqda or ATLAS/ti) the analysis process is cumbersome. ${ }^{4}$

For our complex insurance value topic, only little data on respondent cognitions was available at all - not to speak of pre-fabricated codes. Thus, we accepted the higher analytic

\footnotetext{
${ }^{4}$ Additionally, such software eases quality control by a gapless documentation of the analysis process (Böhm 2004, 485).
} 
Chapter I

effort of GTM, and opted for a research methodology that provides detailed methodological suggestions sufficiently concrete and sufficiently flexible to cope with complexity and novelty. For highly unfamiliar topics, focus groups have an additional, more pragmatic disadvantage: With little initial knowledge available to participants, no interesting discussion is likely to develop without excessive analyst input. Semi-structured personal in-depth interviews allow for an individually adopted communication process in which information is imparted.

If the coding-techniques of GTM are merely used for description, conceptual ordering and discovery of categories to build measurement scales and not to develop any theory at all, results of the analysis process are potentially similar to results generated by other qualitative analysis methods (e.g. Qualitative Content-Analysis; Mayring 1985, 2001). If the research topic is supposed to be more familiar to non-experts or if more a priori knowledge is available to the analyst, other methods such as focus groups may provide an adequate framework for pre-studies of stated preference instruments.

\section{Insurance value of biodiversity}

The ecological insurance hypothesis proposes that biodiversity provides an "insurance" against environmental fluctuations (Loreau et al. 2001; Yachi and Loreau 1999, 1463). The insurance effect is based on at least three phenomena: functional redundancy, functional diversity and dominance of weak trophic interactions (McCann 2000). Suppose an ecosystem faces a drought, then a flood, followed by a fire. It is more likely that a highly diverse ecosystem has some species that can tolerate drought and are fire-tolerant. Some may even be somewhat flood-resistant. If enough individuals of such species survive, the ecosystem may be strongly buffered, and functional ecosystem parameters change little (high ecosystem resistance). Alternatively, it may show resilience: After perturbation it may bounce back to its 
vigorous functional state quickly, because the tolerant individuals of the surviving species drive a fast recovery process, in which they compensate for the loss of their less hardy compatriots (Naeem 2002, 24). A number of theoretical studies have provided support for this hypothesis although experimental evidence remains controversal (Loreau et al. 2003, 12765).

Because many ecosystem services depend not only on species diversity itself but also on ecosystem energy and material flows and their regulation, resistance and resilience are economically relevant (Kutsch et al. 2001). Ecosystems with more diversity of genes, species and habitats provide, as a matter of principle, a better safeguard against changing environmental conditions because they harbour more alternative pathways (e.g. metabolism) in the face of perturbation.

Quite a number of human interventions to the environment cause long-term and persistent damages. Persistent organic pollutants (POP`s) or changes in biotic systems that hold stable for a long time are typical examples (WBGU 1999, 61). Persistent, irreversible and ubiquitous risks deserve special attention. Effects of this risk type are often still unknown or at best presumptions on possible damages. This means, neither the probability of their occurrence nor the extent of the losses they engender is known. WBGU $(1999,161)$ classifies this risk type as Pandora risk. The existence of such a risk type underpins the importance of insurance services: neither the occurrence of the changing environmental conditions nor the dimension of the damage is known. In the face of this extreme uncertainty, risk protection strategies must necessarily be rather unspecific. In addition to containing the risk-bearing agent, engineering science suggests a robust layout of the system that is potentially affected by risk events (the acceptor) as a protection strategy against risks of the Pandora type. Similar to insights gained from the ecological insurance hypothesis, the respective engineering design rules aim at increasing the structural diversity and redundancy of the acceptor system in order to increase its resilience. 


\section{Case study}

Within the post graduate programme "The role of biodiversity for biogeochemical cycles and biotic interactions in deciduous forests" several projects investigate the impact of contrasting tree species diversity on functional ecosystem parameters in deciduous forests of Hainich National Park (Thuringia, Germany). As a subproject of the graduate programme, our study aims at advancing methods for determining the economic value of biological diversity focusing on the economic implications of the ecological insurance hypothesis. To do so, a CE is prepared whose attributes relate to forest- and diversity-related risks along a gradient from well-known to unknown risks.

\subsection{The qualitative interviews}

For the qualitative pre-studies, semi-structured interviews were conducted. The framework for the interview included a set of thirty-two questions. As a characteristic of qualitative research, the interview guide is used as a flexible structure dependent on the interaction with respondents.

The interview guide contains seven main topics:

- The first section deals with perception of nature and the human-nature-relationship (Thompson et al. 1990; Krömker 2003; Barkmann et al. 2005).

- The second section investigates perception and understanding of central terms potentially used in the CE ("healthy forest", "diversity of species").

- In the third part, we explore respondent understanding of the insurance hypothesis. Are respondents able to apply the insurance hypothesis to forest ecosystems, and recognise its economic implications?

- The fourth section introduces the risk protection strategies from engineering science. Are respondents able to apply these strategies to a natural system?

- In the fifth part, respondents are being asked to transfer aspects of everyday insurance (e.g., health insurance) to ecosystem insurance services. 


\section{Chapter I}

- The sixth section deals with new unknown threats to the human-nature-relationship.

- The last section deals with risk and respective coping appraisals (Protection Motivation Theory (PMT); Rogers and Prentice-Dunn 1997).

The interview took, on average, sixty to ninety minutes. Sixteen semi-structured interviews were conducted. Respondents were "laypersons" with regard to knowledge of biology and environmental science. We strove for a balanced distribution of respondents in terms of profession, gender and age.

\subsection{Results of GTM analysis}

In this section, we list exemplary results from the coding strategies of the applied methodology, which were helpful for the development of the CE attributes and the questionnaire framework.

Table 2: Examples of quotes and codings that were directly used for the generation of attributes in the CE questionnaire

\begin{tabular}{|c|c|}
\hline Original text & Open code \\
\hline $\begin{array}{l}\text { Row 32, Interview } 12 \\
\text { R: The giant hogweed was not present in former times and this } \\
\text { problem is getting worse. }\end{array}$ & $\begin{array}{l}\text { The giant hogweed is a } \\
\text { problem/ } \\
\text { threat that is getting worse }\end{array}$ \\
\hline $\begin{array}{l}\text { Row 24, Interview } 15 \\
\text { I: Could you imagine what would happen, if fifty percent of the forest } \\
\text { species diversity in Germany became extint? } \\
\text { R: The balance of nature would be disturbed. } \\
\text { I: And would do you think, what effects could this have? } \\
\text { R: These toxic plants like the giant hogweed could spread out. }\end{array}$ & $\begin{array}{l}\text { Toxic plants like the giant } \\
\text { hogweed are a threat to } \\
\text { balance of nature }\end{array}$ \\
\hline $\begin{array}{l}\text { Row 56, Interview } 7 \\
\text { I: Could you imagine any disturbance that could influence the forest? } \\
\text { R: Yes, bark-beetles for example. If we have a healthy mixed forest, } \\
\text { then only some trees will be ill, but they do not have the chance to } \\
\text { spread out like in a forest monoculture. }\end{array}$ & $\begin{array}{l}\text { Bark-beetles as a threat to the } \\
\text { forest }\end{array}$ \\
\hline $\begin{array}{l}\text { Row 24, Interview } 12 \\
\text { I: Could you imagine what would happen, if fifty percent of the forest } \\
\text { species diversity in Germany became extint? } \\
\text { R: Yes, what will happen? Quite a number of things will happen. First } \\
\text { of all, the climate will change, I mean, we already have the climate } \\
\text { change. }\end{array}$ & $\begin{array}{l}\text { Climate change as a general } \\
\text { threat }\end{array}$ \\
\hline
\end{tabular}


Chapter I

The coding procedure was finished for all sixteen interviews (from open and if meaningful to axial and selective coding level); Table 3 lists only some examples. It was possible to identify the risk perception of respondents (in most cases) associated with biodiversiy decline at the open-coding level (as shown in Table 2). Table 2 represents original text extracts (translated and transcribed from the original interviews in German) from Interviews 12, 15 and 7 (rows $32 / 24,24$ and 56) in order to show exemplarily, how results from analysis were utilised for the CE. Following the rows from the original text extracts to the open coding results, mainly the following threats respondents associated with biodiversity decline become visible:

- non-native species (e.g. giant hogweed),

- diseases, pests and storms related to the forest ecosystem and

- climate change as a possible threat in general or as a threat towards biodiversity, the forests or towards "nature".

Concerning these threats, we abstained from further (and more abstract) coding, as they were mentioned quite frequently and verbatim by the respondents and already represent a relatively high abstraction level. These results which were used for the attributes are discussed more precisely in Section 4.3 .

Aside, this means not as a priori intended aim of analysis, some commonly perceived attitudes on the human-nature-relation and some images of nature emerged in the process of analysis. These are described below in this section.

To introduce our results from the analysis, we want to display some important results for the background of the questionnaire concerning perception of respondents towards basic ideas of the ecological insurance hypothesis. Exemplary results from the open coding process are illustrated using a quote from one of the interviews. The quote is transcribed and 
translated from the German original. The respondent was asked to comment on basic ideas of the ecological insurance hypothesis which were presented beforehand by the interviewer in a simplified form with examples of flooding and climate change. Codes have been excerpted from the interviews and are displayed in square brackets throughout the quote:

"If you have a biological system [perception of ecosystem or nature] with many different species [perception of diversity of species or nature consists of many species], it is more flexible [flexibility, resilience, resistance]. I think, it is also [...] more flexible [...], the more open [openness for future events, option or option value] it is seen from a human point of view [human view, anthropocentric point of view]. Also changes [in vivo change] and new situations [in vivo new situations] with humans show that it can provide a basis of existence [in vivo basis of existence].” (Int. No. 14, line 50-52)

In total, 600 codings (including in vivo codes) were identified by open coding from the transcribed sixteen interviews. Via axial coding, two sets of axes were generated. The selective coding process revealed that the first set of six axes refers to biological diversity and its importance as the central phenomenon. The following set of axes could be generated that summarise interviewee perceptions and valuations with respect to the importance of biological diversity in an insurance value context:

- balance of nature;

- precondition for existence;

- base of life;

- our future;

- animals, humans and environment as a unit;

- protection against disturbance.

These six axes are highly informative by providing an intuitively understandable categorisation of differing respondent respresentations ("what is biodiversity?") and 
Chapter I

valuations ("why is biodiversity important, for example, for humans?").

The second set of axes refers to subjective images of nature and the human-nature relation (1, $2,3,5$; for meaning of numbers, see below) and attitudes towards nature (1a, 1b, 4). In view of interview texts, codes, and categories, the following set of axes was formulated:

1. Vigour of nature

1a. Respect for complexity of nature;

1b. Respect for adaptiveness and flexibility of nature;

2. Existence of nature as evidence for its robustness;

3. Humans as guardians of nature;

4. Fear of and respect for forces of nature;

5. Nature is threatened by human impact.

The axes (1)-(3) express a passive or positive attitude, whereas the last two categories rather focus on threats. Compared with Krömker's $(2004,199)$ images of nature generated from factor analysis of an international sample of college students, certain similarities exist. For example, Krömker $(2004,199)$ also identified a dimension "Nature should be treated with respect", which relates closely to our images and attitudes (1a), (2) and (4). Furthermore, we identified a vigour of nature category under which "Respect for complexity of nature" and "Respect for adaptiveness and flexibility of nature" can be subsumed.

Particularly the resulting axes which represent attitudes and images towards nature are an encouraging result because they make use of the ecological principles that underlie ecosystem resistance and resilience. Based on the awareness that respondents are able to understand the basic principles of the ecological insurance idea, it was justifiable to construct the $\mathrm{CE}$ instrument that requires at least a basic understanding of these principles.

In the following section we specify the results from analysis used for the construction of attributes in the CE design. 


\subsection{Qualitative results in attribute design}

For a plausible questionnaire and interesting attributes that catch respondent attention, it is useful to apply examples and explanations that are well known to respondents. Most of the results from the GTM coding analysis were important mainly as background information of the questionnaire. For the $\mathrm{CE}$ attributes and attribute levels we used risks emerging as important at the open coding level to represent possible and simultaneously well-known threats for the ecosystem services of the Hainich National Park.

In particular, respondents felt threatened by several non-native species such as raccoons (Procyon lotor; interview 12 line 32; int. 13:61) or giant hogweeds (Heracleum mantegazzianum; int. 12:32; int. 15:24). Experts regard invasive species such as the giant hogweed as the second largest threat to biodiversity in Central Europe (Kowarik 2003). Apart from displacement of native species by competition for habitats and resources, invasive nonnative species can harm forestry and agriculture, e.g., by causing harvest losses. Species diversity may reduce the probability of successful invasions of invasive non-native species that can have negative economic, social and conservation-related consequences (Drake and Mooney 1989; UNEP 2003). As Heracleum mantegazzianum was identified as a risk that has to be taken seriously, we decided to use it for the generation of one of the attributes in the CE questionnaire. Heracleum mantegazzianum represents exemplarily the risk of invasive nonnative species in the region of the Hainich National Park (Thuringia). ${ }^{5}$

In detail, there is a set of rather well-known risks associated with neophytes but also some unknown risks. For example, in many cases we are not sure if invasive neobiotic species have negative effects on native species or even ecosystem services or not. Capitalising on this difference, we designed attribute levels that either offer eradication measures only against

\footnotetext{
${ }^{5}$ This utilisation does not require that the Giant Hogweed is a typical forest species.
} 
neophytes for which negative effects are known, or against all neophytes even if it is unclear if they have negative effects or not. The levels used are: (1) removal of harmful nonindigenous plants in particular cases (Status Quo); (2) regular, expanded removal of harmful non-indigenous plants; and (3) removal of all non-indigenous plants.

Similar steps led us to the development of an attribute on "pests and storms". With regard to threats to "the forest", results from the qualitative study showed that respondents felt threatened through tree pests and diseases (Pests: was mentioned in six interviews (number 5, 7-9, 11, 13) Pests and storms: was mentioned in one interview (number 7), bark-beetles (Scolytidae): was mentioned in nine interviews (number 1, 2, 5-7, 12, 9, 10, 16), caterpillar damage: was mentioned in one interview (number 6). Another perceived threat was storms (mentioned in 11 interviews - number 2-5, 7, 9-13 and 15). We bundled these well-known threats into one attribute on forest vulnerability to pests and storms.

The ecological insurance hypothesis can be formulated in relation to species richness (Yachi and Loreau 1999). Stochastic dynamic models provide evidence that asynchronicity of species responses to environmental fluctuations - as introduced by pests and storms - is the basis for an insurance effect (Yachi and Loreau 1999, 1466). For the actual implementation of research on the ecological insurance hypothesis in Central European beech forests in stands with contrasting tree species diversity (DFG-Research Training Group "The Role of Biodiversity für Biogeochemical Cycles and Biotic Interactions in Temperate Deciduous Forests"), no positive proof is available at present with regard to vulnerability to pests and storms. Indicating that this is a simplification, we still decided to relate forest vulnerability to pests and storms to species numbers. In fact, the scientific observations at the Hainich research site aim at testing the implications of the ecological hypotheses for similar stands differing in trees species richness during the years 2005-2009.

In the pilot study, three levels are offered within this attribute: (1) High vulnerability: 1 


\section{Chapter I}

tree species; (2) Medium vulnerability: 2 tree species (status quo); (3) Low vulnerability: 5 tree species. Thus, the species numbers are not presented "alone" in the questionnaire but used as an indicator for a potential cause of different levels of forest vulnerability, i.e. indicating an insurance service for Hainich forest stands.

Qualitative data analysis had shown that tree species numbers are at times associated with the aesthetic value of more diverse forests. We decided to accept this potential association of aesthetic and functional benefits because the focus of the attribute was clearly directed towards vulnerability toward pests and storms. Interestingly, the preliminary studies also revealed that respondents had a stronger perception for the disadvantages of a forest monoculture than for the advantages of forest diversity. This pattern has an important implication for the design of attribute levels: It may indicate strongly decreasing marginal WTP for improvements of the status quo, while respondents may be highly sensitive to degradations of the current ecological situation. In order to test if this 'endowment effect' occurs (Kahneman et al. 1991), we made sure that the status quo attribute level was accompanied by a better and a worse attribute.

In the qualitative preliminary studies interviews, climate change figured prominently as a well-known 'threat' (climate change: was mentioned in seven interviews (number 5, 7-9, 12, 14, 15); global warming: was mentioned in four interviews (number 3, 6, 13, 16). Long-term weather recordings demonstrate that Germany is affected by climate change (Zebisch et al. $2005,6)$. The annual average temperature increased by ca. 0.8 to $1^{\circ} \mathrm{C}$ between 1900 and 2000 (Zebisch et al. 2005, 6). Additionally, the intensity and frequency of occurrence of extreme rainfall events and the probability of occurrence of heat days have increased especially during the last forty years of the 20th century and over the last one hundred years respectively (Zebisch et al. 2005, 6).

The projected climate change is supposed to lead to serious habitat and species losses 
Chapter I

(European Environmental Agency 2005, 3). Species and habitats, on their part, provide essential and diverse benefits such as regulating, provisioning, supporting and cultural services (UNEP 2003, 8). Forests, in particular, can contribute to climate regulation as they mitigate negative impacts of $\mathrm{CO}_{2}$ emissions by fixing atmospheric carbon. Respondents realise this as one of the most important environmental services of forest ecosystems. In spite of the mounting evidence for the influence of anthropogenic carbon emissions on climate change, there is still some public discussion on how dangerous climate change is and on what should or should not be done about it. This documents a substantial remaining measure of uncertainty with regard to the seriousness of climate change related risks.

For the CE pre-test interviews, we decided to include the attribute "contribution to climate stability by carbon sequestration" that refers to the bio-geographic regions of the Hainich forest and the Weser-Leine-Highlands (116.000 ha of forest). Measures of the attribute levels are implemented hypothetically by planting additional trees aiming to increase carbon sequestration. The attribute levels are quantified in percent changes relative to current sequestration rates (see Table 3). Although total sequestered $\mathrm{C}$-amounts in tons were presented in the explanation of the attribute levels in the questionnare, the choice cards only displayed the percent changes because respondents seemed to feel quite unfamiliar in the very first test interviews with an attribute quantification based on number of tons of $\mathrm{CO}_{2}{ }^{6}$. Generally, healthy forests represent a yearly averaged C-sink which lies often between 300 and $500 \mathrm{~g} \mathrm{C} \mathrm{m}^{-2} \mathrm{a}^{-1}$ if the absorption rate of the whole ecosystem is taken into account (Knohl et al. 2003). If the absorption rates of the soil are considered separately, numbers of sequestration range between $2.4 \mathrm{~g} \mathrm{C} \mathrm{m}^{-2} \mathrm{a}^{-1}$ (Switzer et al. 1979), $9.4 \mathrm{~g} \mathrm{C} \mathrm{m}^{-2} \mathrm{a}^{-1}$ (Robertson and Vitousek 1981) and 60-80 $\mathrm{g} \mathrm{C} \mathrm{m}^{-2} \mathrm{a}^{-1}$ (Jenkinson 1971). We calculated the C-sequestration rate

\footnotetext{
${ }^{6}$ In the main study, we quantified carbon sequestration by emission equivalents per capita (see chapter III and IV, this thesis).
} 
for the Hainich forest and Weser-Leine-Highlands with about $5 \mathrm{~g} \mathrm{C} \mathrm{m}^{-2} \mathrm{a}^{-1}$ which seems quite realistic for a 250 year-old forest because at this age $\mathrm{C}$-absorption takes mainly place in the soil (Robertson and Vitousek 1981). With a yearly production of 20 tons $\mathrm{CO}_{2}$ per average two-person-household (UNFCCC 2006), the forest area is equivalent to about 1,000 years of $\mathrm{CO}_{2}$ emissions ${ }^{7}$. On the choice cards, we presented the levels with values on increased Csequestration in percent changes relative to current sequestration rates: (1) $0 \%$ more carbon sequestration (Status Quo), (2) 5\% more carbon sequestration, (3) $10 \%^{8}$ more carbon sequestration.

Apart from ecosystem services that include protection against more or less known risks to the human-nature-relationship, we are especially interested in the perception and valuation of threats by unknown risks. Species numbers of soil organisms were considered as a suitable indicator. Here, no indication was obtained that respondents would focus on aesthetic diversity benefits distracting from the functional importance of a diverse soil community. Explaining to respondents the importance of soil organisms for the fundamental functioning of terrestrial ecosystems (e.g., Balser et al. 2002, 265), we argued that the majority of soil organisms as part of biodiversity is important, even if it is not visible. Explicitly applying the ecological insurance argument, we pointed at the importance of the diversity of the soil organism community for the resistance and resilience of forest ecosystems.

In the face of expected changes in global climate for instance, there is a lively debate about whether it is possible to predict which species will become important in the future (Lawler et al. 2001, 302). Many scientists feel that such predictions cannot be made with much confidence, so the wisest course of action is to preserve as many species as possible (Myers 1996; Gitay et al. 1996; Edwards and Abivardi 1998). At least implicitly, this ar-

\footnotetext{
${ }^{7}$ It was calculated with 2.7 tons $\mathrm{C}$ as measuring unit per person because the quoted 10 tons refer to $\mathrm{CO}_{2}$ as measuring unit per person.

${ }^{8}$ One criticism of our approach (pilot study) might be that sequestration rates present an overestimation.
} 


\section{Chapter I}

gumentation makes use of an insurance value argument by species diversity. In line with the ecological insurance hypothesis (Yachi and Loreau 1999), such insights suggested to use species numbers as an indicator for another long-term insurance service: "Vulnerability against unknown threats" with the three levels (1) High vulnerability: Low number of soil species; (2) Medium vulnerability: medium number of soil species; (3) Low vulnerability: high number of soil species.

Table 3: Attributes and levels of the CE used in pre-test interviews

\begin{tabular}{ll}
\hline Attribute & Level \\
\hline 1. Contribution to climate stability through & $1.0 \%$ more carbon sequestration $*$ \\
carbon sequestration (risks through climate & $2.5 \%$ more carbon sequestration \\
change): additional carbon sequestration of the & $3.10 \%$ more carbon sequestration \\
forest ecosystem in percent &
\end{tabular}

2. Risks by non-indigenous plants: Measures against non-indigenous plants
1. Removal of harmful non-indigenous plants in particular cases*

2. Regular, expanded removal of harmful nonindigenous plants

3. Removal of all non-indigenous plants
1. High vulnerability - 1 tree species

2. Medium vulnerability - 2 tree species*

3. Low vulnerability - 5 tree species
4. Vulnerability against (new) unknown threats: species of the forest soil used as indicator for resistance and resilience (non aesthetic value)
1. High vulnerability: Low number of soil species

2. Medium vulnerability: medium number of soil species*

3. Low vulnerability: high number of soil species

5. Cost attribute: ,extra duty“ per year and

$0^{*}, 5,6,8,10,15,20,25,40$ Euro household

*denotes the status quo. Source: Own investigation.

\subsection{Building blocks for communicating the insurance concept}

We are now in the position to evaluate if the relation between biodiversity, the resilience and resistance of ecological systems, and their economic importance is likely to be understood by respondents as intended. A priori, we had identified the following building blocks for a scientifically adequate understanding: 
Chapter I

1. awareness that humans are part of ecological systems,

2. role of species diversity for flexible ('resilient') ecosystem response.

Furthermore for an adequate understanding of the insurance effect of biological diversity on unknown risks to the human-environment relation, an additional building block must be given:

3. awareness that the ecosystem service risk protection against unknown risks does not necessarily protect against known risks.

The frequency of codes such as "with more species, survival chances increase", "decreasing species diversity has negative effects on humans", or "species diversity might be useful for humans" indicates the building blocks (1) and (2) are unlikely to become a problem. The tendency to view biological diversity as an environmental good that supplies and secures all kinds of ecosystem services points at potential problems with the third building block. The surprisingly high WTP for protection of unknown risks in the investigation of Witte (2005) may be an expression of this potential problem.

\section{Conclusion}

As expected, qualitative data analysis with GTM strategies led to a deeper insight into the perceptions non-expert respondents hold with regard to the different ecological and economic aspects of the ecological insurance hypothesis. To obtain these insights, we followed an inductive analytical approach including an extensive, multi-step coding process. This process generated several axes that (i) provided insight into the general patterns of the description and appreciation of biodiversity, and (ii) pointed at commonly held images of nature and attitudes 


\section{Chapter I}

towards the human-nature-relation. In sum, the axes suggest that non-experts have several concepts on nature and on biodiversity that relate well to the fundamental ideas of ecological risk insurance. This result allows us to deflect one of the most serious challenges likely to be brought against any attempt to quantify the value of precautionary insurance against unspecific or even completely unknown ecological risks: the objection that such insurance benefits stem from aspects of ecosystem functioning with which average non-expert respondents are utterly unfamiliar. This means, central elements of the investigated insurance services appeared less unfamiliar to respondents than expected.

The advantages of the inductive focus and the richness of data generated by GTM strategies come at a cost, however: only part of the specific design issues for the $\mathrm{CE}$ instrument could be solved directly by reference to GTM results. Thus, utilisation of results from GTM analysis were restricted mainly to (i) an elucidation of the general background of the construction of the CE instrument, (ii) help in solving a few specific wording issues, and (iii) a justification of the attempt to quantify preferences for a highly unfamiliar ecosystem service. Using hierarchically 'low' GTM coding levels, (iv) attribute design could be based on data on declarative respondent knowledge about ecological risks. The identified risks that were directly used for attribute development were risks of non-indigenous plants, risks posed by diseases, pests and storms to the forest ecosystem, and risks by climate change. The codes derived from the GTM application could, however, be generated by any other qualitative social science method.

The specific aims of our study could not have been achieved with focus groups. First, we needed a qualitative data collection and communication method that allows for highly individualised interaction between interviewer and interviewee because at least the more technical aspects of ecological risk insurance are highly unfamiliar to non-experts. Group discussions are structurally less suitable in this situation. More importantly, a qualitative 
research strategy was called for that maximises the opportunity to learn in depth, how potential survey respondents conceptualise the key principles of ecological risk insurance provided by biological diversity. The methodologically detailed, inductive approach of GTM provided exactly this opportunity. In contrast, the methodological suggestions for standard applications of focus groups are much less sophisticated in this regard.

It has to be emphasized that the topic of our CE goes far beyond the charted terrain for standard applications of stated preference methods. For more conventional applications, GTM may in fact not be an efficient choice for the preliminary studies phase. The coding process of GTM is very time-consuming, and the extremely inductive approach may only accidentally contribute to the most urgent instrument design issues. Thus, more full-fledged applications of GTM can only be recommended for studies, (i) in which relatively little is known about the subjective understanding of respondents regarding the valuation issue at hand, or (ii) in which an unusually rich set of background information is required or striven for. In most other cases, other methods are likely to allow for an adequate and more efficient construction of a CE survey instrument (e.g. Qualitative Content-Analysis; Mayring 1985, 2001).

\section{Acknowledgement}

The presented project is funded by DFG, and part of the DFG-Research Training Group "The role of biodiversity for biogeochemical cycles and biotic interactions in temperate deciduous forests" coordinated by the Center of Biodiversity Research and Ecology at Georg-August Universität Göttingen. It is integrated in the junior research group "Valuation of ecosystem functions and services" at the Department of Environmental Economics and Rural Development, Georg-August-Universität Göttingen. We thank D. Krömker, C. Leuschner and R. Marggraf for much appreciated advice, and two anonymous reviewers for helping to improve a previous version of this manuscript. 


\section{References}

Arrow K, Solow R, Portney PR, Learner EE, Radner R, Schuman H (1993) Report of the NOAA Panel on Contingent Valuation. Resources for the Future, Washington D.C. Agar M, MacDonalds J (1995) Focus groups and ethnography. Human Organization 54:78-86 Balser TC, Kinzig AP, Firestone MK (2002) Linking Soil Microbial Communities and Ecosystem Functioning. In: Kinzig AP, Pacala SW, Tilman D (eds) The Functional Consequences of Biodiversity. Princeton University Press, Princeton, Oxford, p 265293

Barkmann J, Marggaf R (2004) The long-term protection of biological diversity. Lessons from market ethics: Poesis and Praxis. International Journal of Ethics and Technology Assessment 3:3-21

Barkmann J, Cerda C, Marggraf R (2005) Interdisziplinäre Analyse von Naturbildern:

Notwendige Voraussetzung für die ökonomische Bewertung der natürlichen Umwelt. Umweltpsychologie 9:10-29

Bateman IJ, Carson RT, Day B, Hanemann M, Hanley N, Hett T, Jones-Lee M, Loomes G, Mourato S, Özdemiroglu E, Pearce OBE DW, Sugden R, Swanson J (2002) Economic valuation with Stated Preference Techniques: A manual. Edward Elgar, Cheltenham, Northhampton

Bogdan RB, Biklin SK (1998) Qualitative Research for Education: An Introduction to Theory and Methods, Third Edition. Allyn and Bacon, Needham Heights

Böhm A (2004) Theoretisches Codieren: Textanalyse in der Grounded Theory. In: Flick U, v. Kardoff E, Steinke I (Hrsg) Qualitative Forschung. Ein Handbuch. Rowohlt, Reinbek b. Hamburg, p 475-485

Bryman A (2004) Social Research Methods. Oxford University Press, Oxford

Drake JA, Mooney HA (1989) Biological invasions: a global perspective. John Wiley and Sons, Chichester

Edwards PJ, Abivardi C (1998) The value of biodiversity: where ecology and economy blend. Biological conservation 83:239-246

European Environment Agency (2005) Anfälligkeit für die Folgen der Klimaänderung und Anpassung an die Klimaänderung in Europa. Accessed 10 December 06 www.eea.europa.eu

Gill B (1998) Ungewißheit, administrative Entscheidung und Demokratie - die neuen Anforderungen durch die Gentechnik. Österreichische Zeitschrift für 
Politikwissenschaft 27:29-45

Gitay H, Wilson JB, Lee WG (1996) Species redundancy: a redundant concept? Journal of Ecology 84:121-124

Glaser BG, Strauss AL (1998) Grounded Theory, Strategien qualitativer Forschung. Hans Huber, Bern

Jenkinson DS (1971) The accumulation of organic matter in soil left uncultivated.

Rothamsted Experimental Station Report for 1970, p 113-137

Jungermann H, Slovic P (1993) Die Psychologie der Kognition und Evaluation von Risiko. In: Bechmann G (Hrsg) Risiko und Gesellschaft. Westdeutscher Verlag, Opladen, p $167-207$

Kahneman D, Knetsch JL, Thaler RH (1991) The Endowment Effect, Loss Aversion, and Status Quo Bias. Journal of Economic Perspectives 5:193-206

Knohl A, Schulze ED, Kolle O, Buchmann N (2003) Large carbon uptake by an unmanaged old deciduous forest in Central Germany. Agricultural and Forest Meteorology 118:151-167

Kowarik I (2003) Biologische Invasionen. Neophyten und Neozoen in Mitteleuropa. Ulmer, Stuttgart

Krömker D (2003) Climate Change from International Perspective: Image of Nature as Cultural Background for the Acceptance of Protection Measures. Open Meeting of the Global Environmental Change Research Community, Montreal, 16-18 October 2003, p $1-17$

Krömker D (2004) Naturbilder, Klimaschutz und Kultur. Beltz, Weinheim, Basel, Berlin

Kutsch W, Steinborn W, Herbst M, Baumann R, Barkmann J, Kappen L (2001) Environmental Indication: A Field-test of an Ecosystem Approach to Quantify Biological Self-organization. Ecosystems 4:49-66

Lawler S, Armesto JJ, Kareiva P (2001) How Relevant to Conservation Are Studies Linking Biodiversity and Ecosystem Functioning? In: Kinzig AP, Pacala SW, Tilman D (eds) The Functional Consequences of Biodiversity. Princeton University Press, Princeton, Oxford, p 294-313

Liebe U, Meyerhoff J (2007) A Sociological Perspective on Stated Willingness to Pay. In: Meyerhoff J, Lienhoop N, Elsasser P (eds) Stated Preference Methods for Environmental Valuation: Applications from Austria and Germany. Metropolis, Marburg p 253-282 
Loreau M, Naeem S, Inchausti P, Bengtsson J, Grime JP, Hector A, Hooper DU, Huston A, Reffaelli D, Schmid B, Tilman D, Wardle DA (2001) Biodiversity and Ecosystem Functioning: Current Knowledge and Future Challenges. Science`s Compass Review 294: 804-808

Loreau M, Mouquet N, Gonzalez A (2003) Biodiversity as spatial insurance in heterogeneous landscapes. The Proceedings of the National Academy of Sciences 100:12765-12770 Mayring P (1985) Qualitative Inhaltsanalyse. In: Jüttemann G (Hrsg) Qualitative Forschung in der Psychologie. Beltz, Weinheim, Basel, p 187-211

Mayring P (2001) Kombination und Integration qualitativer und quantitativer Analyse. Forum Qualitative Sozialforschung. Accessed 10 January 07 www.qualitative-research.net/fqstexte/1-01/1-01mayring-d.htm

McCann KS (2000) The diversity-stability debate. Nature 405:228-233

Mitchell RC, Carson RT (1989) Using Surveys to value public goods: The Contingent Valuation Method. Resources for the Future, Washington D.C.

Myers N (1996) Environmental services of biodiversity. Proceedings of the National Academy of Sciences of the United States of America 93:2764-2769

Naeem S (2002) Biodiversity: Biodiversity equals instability? Nature 416:23-24

Perrings C (1991) Reserved rationality and the precautionary principle: technological change, time and uncertainty in environmental decision making. In: Constanza R (ed)

Ecological Economics: The Science and Management of sustainability. Columbia University Press, New York

Perrings C (1995) Biodiversity conservation as insurance. In: Swanson TM (ed) The economics and ecology of biodiversity decline: The forces driving global change. Cambridge University Press, Cambridge, New York, Melbourne p 69-77

Puchta C, Wolff S (2004) Diskursanalysen institutioneller Gespräche - das Beispiel von "Focus Groups". In: Keller R, Hirseland A, Schneider W, Viehöver W (eds) Handbuch Sozialwissenschaftliche Diskursanalyse, Leske \& Budrich, Opladen, p 439-454

Robertson GP, Vitousek PM (1981) Nitrification potentials in primary and secondary succession. Ecology 62:376-386

Rogers RW, Prentice-Dunn S (1997) Protection Motivation Theory. In: Gochman DS (ed) Handbook of Health Behaviour Research. New York, p 113-132

Saludadez JA, Garcia PG (2001) Seeing Our Quantitative Counterparts: Construction of Qualitative Research in a Roundtable Discussion. Accessed 10 January 07 
www.qualitative-research.net/fqs-texte/1-01/1-01 saludadezgarcia-e.htm

Schmidt I, Jungkunst HF, Brauns M, Daenner KM, Fahrenholz N, Fornaçon C, Gebauer T, Gollisch J, Guckland A, Lang C, Meinen C, Mölder A, Rajmis S, Sobek S, Talkner U, Thomas F, Leuschner C (2006) Trends in biodiversity, biotic interactions and biogeochemical cycles due to tree species diversity in a Central-European deciduous forest. Ecological Society of Germany, Switzerland and Austria (GfÖ) 2006. Poster Symposium 06 Biodiversity on different spatial scales, p 151

Strauss A, Corbin J (1996) Grounded Theory: Grundlagen Qualitativer Sozialforschung. Beltz, Weinheim

Strauss A, Corbin J (1998) Basics of Qualitative Research: Techniques and Procedures for Developing. Thousand Oaks, London, New Delhi

Switzer GL, Shelton MG, Nelson LE (1979) Successional development of the forest floor and oil surface on upland sites of the east gulf coastal plain. Ecology 60:1162-1171 Thompson M, Ellis R, Wildavsky A (1990) Cultural Theory: The Social Construction of Nature. Westview Press, Boulder

Turner RK (2001) The Place of Economic Values in Environmental Valuation. In: Bateman IJ, Willis KG (eds) Valuing Environmental Preferences. Theory and Practice of the Contingent Valuation Method in the US, EU, and Developing Countries. Oxford University Press, Oxford, p 17-41

UNEP [United Nations Environment Programme] (2003) Millennium Ecosystem Assessment: Ecosystems and Human Well-being. Island Press, Washington, Covelo, London UNFCCC [United Nations Framework Convention on Climate Change] (2006) Carbon dioxide emissions (CO2), metric tons of $\mathrm{CO} 2$ per capita. Accessed 31 January 07 http://mdgs.un.org/unsd/ mdg/ SeriesDetail.aspx?srid=752

WBGU [Wissenschaftlicher Beirat der Bundesregierung Globale Umweltveränderungen] (1999) Jahresgutachten 1998. Strategien zur Bewältigung Globaler Umweltrisiken. Springer, Berlin, Heidelberg, New York (available in English)

WCED [World Commission on Environment and Development] (1987) Our common future. Report of the World Commission on Environment and Development. Oxford University Press, Oxford

Witte JP (2005) Determination of willingness to pay for "Ecosystem Health" in terms of prevention of unknown environmental dangers in Central Sulawesi (Indonesia): a choice experiment approach. Diploma Thesis at the Department of Geography, Georg- 
Chapter I

August-Universität Göttingen, Germany

Yachi S, Loreau M (1999) Biodiversity and ecosystem productivity in a fluctuating environment: the insurance hypothesis. Proceedings of the National Academy of Sciences of the U.S.A. 96:1463-1468

Zebisch M, Grothmann T, Schröter D, Haße C, Fritsch U, Cramer W (2005) Klimawandel in Deutschland. Vulnerabilität und Anpassungsstrategien klimasensitiver Systeme. Institut für Klimafolgenforschung, Postdam, p 2-12 


\section{Chapter II}

\section{Der ökonomische Wert von Versicherungsdienstleistungen der Biodiversität gegen bekannte und unbekannte Risiken am Beispiel des Hainich National Parks (Thüringen)*}

Sandra Rajmis, Jan Barkmann und Rainer Marggraf

\section{Einleitung}

Versicherungseffekte der Biodiversität tragen zur Stabilisierung ökosystemarer Funktionen bei und sichern damit die Bereitstellung ökosystemarer Dienstleistungen in Hinblick auf Umweltveränderungen (Yachi und Loreau 1999). Ökosystemare Dienstleistungen sind die von der Biodiversität bzw. dem Ökosystem bereitgestellten Leistungen, die der Gesellschaft direkt oder indirekt Nutzen stiften (z. B. die Versorgung mit Holz, die Regulierung des Klimas oder die Speicherung von Wasser für Nutzzwecke).

Nach der Versicherungshypothese (Yachi und Loreau 1999, McCann 2000) sorgt eine hohe Artenvielfalt beispielsweise dafür, dass die zeitliche Varianz zentraler Ökosystemparameter der Tendenz nach sinkt. Sind in einem Ökosystem mehr Arten vorhanden, steigt beispielsweise die Wahrscheinlichkeit, dass eine Art die Funktion einer anderen übernehmen kann (funktionale Redundanz, Tilman et al. 1996). Dies führt tendenziell dazu, dass weniger ausgeprägte Schwankungen von Ökosystemfunktionen (z.B. bei der pflanzlichen Produktion) auftreten. Es kann aber auch zu Umweltveränderungen kommen, die den verstärkten Einsatz von bestimmten Ökosystemprozessen fordern, die bisher keine

\footnotetext{
* A similar version of the manuscript was published in 'Naturschutz und Biologische Vielfalt 60: Naturschutz und Ökologie - Ausgewählte Beiträge zur GfÖ-Jahrestagung in Marburg 2007’
} 
Chapter II

bedeutende Rolle gespielt haben. Ein Ökosystem mit vielen Arten besitzt mit höherer Wahrscheinlichkeit Organismen, die über die in der neuen Situation erforderlichen Funktionsmöglichkeiten verfügen. Man spricht in diesem Fall von der funktionalen Diversität (McCann 2000).

Von einem ökonomischen Standpunkt aus betrachtet sind Investitionen in den Biodiversitätsschutz zumeist eine profitable Versicherung für die Gesellschaft, die in Abhängigkeit von funktionsfähigen Ökosystemen steht.

Anhand eines Choice Experiments ermitteln wir empirisch, ob in der Bevölkerung eine Zahlungsbereitschaft für die Sicherung des ökosystemaren Zustandes von Laubwäldern im Hinblick auf deren Funktion einer Vorsorge vor bestimmten Risiken bzw. Gefährdungen besteht. Wir beziehen uns dabei exemplarisch auf die Hainich Nationalpark-Region in Thüringen. Als entsprechende ökologische Versicherungsdienstleistungen der Waldbiodiversität im Bereich des Hainich Nationalparks haben wir basierend auf einer qualitativen Studie die folgenden identifiziert: Versicherungsdienstleistungen der Waldbiodiversität gegenüber Klimaveränderungen, Stürmen und Schädlingen, sowie gegenüber Risiken, die neu oder unbekannt sind. Zudem haben wir Zahlungsbereitschaften für die Entfernung von invasiven Arten wie dem Riesenbärenklau untersucht.

\section{Methodischer Hintergrund: Das Choice Experiment}

Ursprünglich im Marketing verwendet, haben Choice Experimente in den letzten Jahren zunehmend Eingang in die Umweltbewertung gefunden. Grundlegend ist die Idee, dass man Umweltgüter anhand ihrer Eigenschaften beschreiben und bewerten kann (Hensher et al. 2005, Adamowicz et al. 1998). Dabei werden Umfragen mit strukturierten Interviews durchgeführt. Die Befragungssituation simuliert dabei einen Markt für Umweltgüter, da es für 


\section{Chapter II}

die meisten dieser Güter keine Märkte gibt und somit keine monetäre Dimensionierung vorliegt.

In Vorbereitung auf das Choice Experiment werden DIN A5-Karten angefertigt. Die Karten zeigen die Eigenschaften des Umweltguts in verschiedenen Ausprägungen, die nach einem statistischen Design (fractional factorial design, s. Hensher et al. 2005) erstellt werden. In einem „Choice Set“ werden den Befragten jeweils drei Karten zur Auswahl vorgelegt. Zwei der Karten stellen unterschiedliche Schutzmaßnahmen für eine Veränderung bzw. Verbesserung des Umweltgutes (Maßnahme A und B) dar, auf einer dritten Karte wird der jetzige Zustand des Umweltgutes (hier der Versicherungsdienstleistungen der Waldbiodiversität) dargestellt.

Die Befragten werden gebeten, eine der drei Karten auszuwählen. Dieser Vorgang wird je nach Untersuchungsdesign (bei unserem Choice Experiment insgesamt acht Mal) wiederholt. Da Schutzmaßnahmen in der Regel Geld kosten, befindet sich auf den Karten zudem ein Kostenattribut („Hypothetische Kosten zur Umsetzung der Maßnahme“). Daher kann, basierend auf den Auswahlentscheidungen der Befragten, eine durchschnittliche Zahlungsbereitschaft für die Versicherungsdienstleistungen der Waldbiodiversität ermittelt werden. Die Höhe der Zahlungsbereitschaft kann wiederum in Bezug gesetzt werden zu soziodemographischen Parametern (z.B. Einkommen, Alter und Geschlecht). Ebenso untersuchen wir, ob die Einstellungen der Befragten zu ökologischen Risiken die Zahlungsbereitschaft beeinflussen. Die Zahlungsbereitschaft (= der Nutzen der Bevölkerung) kann in einem weiteren Schritt den Kosten der Schutzmaßnahmen z.B. im Rahmen einer Kosten-Nutzen-Analyse gegenüber gestellt werden. 


\section{Auswahl der Umweltgüter bzw. ökosystemaren Dienstleistungen}

Vorstudien sind eine grundlegende Voraussetzung für die Anwendung von Stated Preference

Studien inklusive Choice Experimenten (Arrow et al. 1993, Barkmann et al. 2005).

Insbesondere die Bewertung von Umweltgütern oder ökosystemaren Dienstleistungen stellt eine Herausforderung dar, da die Befragten mit dem Gut oder der Dienstleistung weniger vertraut sind als mit (greifbaren und direkten) Marktgütern.

Tabelle 1. Die im Choice Experiment verwendeten Umweltgüter bzw. Versicherungsdienstleistungen der Waldbiodiversität

\begin{tabular}{|c|c|}
\hline $\begin{array}{l}\text { Umweltgut bzw. } \\
\text { Versicherungsdienstleistung der } \\
\text { Waldbiodiversität }\end{array}$ & $\begin{array}{l}\text { Schutzmaßnahme/Ausprägung des Umweltguts bzw. der } \\
\text { Versicherungsdienstleistung }\end{array}$ \\
\hline $\begin{array}{l}\text { 1. Schutz vor Gefahren durch } \\
\text { Klimaveränderungen }\end{array}$ & $\begin{array}{l}\text { Durch zusätzliche Neuanpflanzungen variierende Kohlenstoffbindung } \\
\text { im Verhältnis zur jährlichen pro-Kopf } \mathrm{CO}_{2} \text {-Produktion }\end{array}$ \\
\hline 2. Schutz vor Gefahren durch & Durch zusätzliche Neuanpflanzungen von speziell standorttypischen \\
\hline Schädlinge \& Stürme ${ }^{1}$ & $\begin{array}{l}\text { Baumarten variierende Widerstandskraft des Waldes. Da die } \\
\text { Baumartenzahl nicht unabhängig vom Standort ist, wurde im } \\
\text { Fragebogen von der Angabe einer konkreten Artenzahl abgesehen. }{ }^{2} \\
\text { Stattdessen bieten wir im Fragebogen „Geringe, mittlere und hohe } \\
\text { Widerstandskraft“ an. }\end{array}$ \\
\hline 3. Schutz vor unbekannten Gefahren ${ }^{3}$ & $\begin{array}{l}\text { Durch Mykorrhiza-fördernde Maßnahmen variierende Widerstandskraft } \\
\text { des Waldökosystems. In Anwendung des ökologischen } \\
\text { Versicherungsschutzes (Yachi und Loreau 1999, McCann 2000) } \\
\text { betonen wir die Wichtigkeit der Vielfalt der Mykorrhiza für die } \\
\text { Resistenz und Resilienz des Waldökosystems. Auch hier bieten wir im } \\
\text { Fragebogen „Geringe, mittlere und hohe Widerstandskraft“ an. }\end{array}$ \\
\hline $\begin{array}{l}\text { 4. Schutz vor Gefahren durch nicht- } \\
\text { einheimische Pflanzen }\end{array}$ & $\begin{array}{l}\text { Durch exemplarische variierende Bekämpfungsmaßnahmen gegen } \\
\text { nicht-einheimische Pflanzen am Beispiel des Riesenbärenklaus }(H \text {. } \\
\text { mantegazzianum })\end{array}$ \\
\hline 5. „Kosten der Maßnahme“ als & $5 €-80 €$ für die „Verbesserungsmaßnahmen“ \\
\hline Sonderabgabe pro Person und Jahr & $0 €$ für den „Jetzigen Zustand““ \\
\hline
\end{tabular}

1 Stochastische Modelle zeigen, dass die Asynchronizität der Artenreaktionen gegenüber veränderten Umweltbedingungen - wie z.B. Stürmen oder Schädlingsbefall - die Basis für den Versicherungseffekt bilden (Yachi \& Loreau 1999, 1499).

${ }^{2}$ Die Anfälligkeit gegenüber Gefährdungen wurde mit „standorttypischen“ bzw. „nicht standorttypischen“ Baumarten ausgedrückt.

3 Dieses Umweltgut bzw. diese Dienstleistung gibt keinen Anlass zu einer ,ästhetischen“ Bewertung und fokussiert somit auf die funktionale Bedeutung der symbiotischen „Baumwurzelpilze“ (mit diesem Begriff im Fragebogen).

${ }^{4}$ Experten betrachten invasive Pflanzen als die zweitgrößte Bedrohung der Biodiversität (Kowarik 2003). Neben dem Konkurrenzverhalten in Bezug auf Habitate und Ressourcen, können invasive Pflanzen auch in der Forst- und Landwirtschaft Schaden anrichten. 
Chapter II

Die im Experiment verwendeten Versicherungsdienstleistungen sind das Ergebnis einer qualitativen Studie $(\mathrm{n}=16$ Interviews), eines Pretests $(\mathrm{n}=57$ Interviews $)$ und einer Pilotstudie ( $\mathrm{n}=106$ Interviews). In Tabelle 1 sind die Versicherungsdienstleistungen der Waldbiodiversität mit ihren Ausprägungen dargestellt. Sie beschreiben die ökosystemare Vorsorge bzw. den Versicherungsschutz vor den dargestellten exemplarischen Gefährdungen. Die Ausprägungen beschreiben verschiedene Varianten dieses Versicherungsschutzes bzw. der Bekämpfungsmaßnahmen bei den nicht-einheimischen Pflanzen.

\section{Durchführung und Auswertung des Choice Experiments}

Im Choice Experiment wählt jeder Befragte durch die Auswahl einer Karte mit den dargestellten Veränderungen der Versicherungsdienstleistungen aus so genannten Güterbündeln aus, d.h. das Umweltgut und deren Ausprägungen werden nicht einzeln bewertet, sondern insgesamt bzw. gebündelt. Um aber Aussagen über die Zahlungsbereitschaft für die Veränderungen des jeweiligen Umweltgutes treffen zu können, müssen die Güter in der Auswertung einzeln betrachtet werden. Die Zahlungsbereitschaft bezieht sich genau auf eine Einheit der jeweiligen Ausprägung (z. B. ,geringe, mittlere oder hohe Widerstandskraft gegen Schädlinge und Stürme") und wird als marginal bezeichnet. Diese marginale Zahlungsbereitschaft ist in der folgenden Tabelle 2 dargestellt.

Es können verschiedene ökonometrische Schätzverfahren zur Analyse der Ergebnisse eingesetzt werden (Hensher et al. 2005, Adamowicz et al. 1998). Sie schätzen den Einfluss der verschiedenen Ausprägungen der Versicherungsdienstleistungen der Waldbiodiversität und den Einfluss von Merkmalen der Befragten (z.B. Alter, Einkommen oder Risikowahrnehmung) auf die Wahrscheinlichkeit, eine bestimmte Karte mit den dargestellten Veränderungen der Versicherungsdienstleistungen auszuwählen. Wir haben zur Auswertung 


\section{Chapter II}

Nested Logit Modelle verwendet (Hensher et al. 2005), die auf weniger restriktiven Annahmen beruhen als z. B. die einfacheren Multinomial Logit Modelle (ebd.).

\section{Ergebnisse und Diskussion}

In der Hauptbefragung wurden insgesamt 302 Personen aus 14 Gemeinden in der Nähe des Nationalparks sowie der Stadt Eisenach befragt. 282 Personen haben den Fragebogen vollständig beantwortet. Die Hauptbefragung wurde zwischen Oktober und Dezember 2006 durchgeführt. Im Durchschnitt dauerte ein Interview ca. 35 Minuten und kam am häufigsten beim ersten Kontakt der Interviewer mit den Befragten zustande (59\% der Fälle).

Tabelle 2. Marginale Zahlungsbereitschaften (ZB) für die bewerteten Umweltgüter bzw. Versicherungsdienstleistungen der Waldbiodiversität

\begin{tabular}{|c|c|c|}
\hline \multirow{2}{*}{$\begin{array}{l}\text { Versicherungsdienstleistung der Waldbiodiversität } \\
\text { in der folgenden exemplarischen Ausprägung }\end{array}$} & Grundmodell & Marginale ZB \\
\hline & Koeffizient & {$[€ /$ Person/Jahr] } \\
\hline $\begin{array}{l}\text { 1. Veränderung der „,Kohlenstoff-Bindung der Emissionen von } 540 \\
\text { Personen“ zur „Kohlenstoff-Bindung der Emissionen von } 630 \text { Personen“ }\end{array}$ & $0,354 * * *$ & 20,01 \\
\hline $\begin{array}{l}\text { 2. Veränderung der "mittleren Widerstandskraft gegen Schädlinge und } \\
\text { Stürme" zur "hohen Widerstandskraft gegen Schädlinge und Stürme" }\end{array}$ & $0,454 * * *$ & 25,71 \\
\hline $\begin{array}{l}\text { 3. Veränderung der "mittleren Widerstandskraft gegen unbekannte } \\
\text { Gefahren" zur "hohen Widerstandskraft gegen unbekannte Gefahren" }\end{array}$ & $0,278 * * *$ & 15,71 \\
\hline $\begin{array}{l}\text { 4. Veränderung der „regelmäßigen großflächigen Entfernung des } \\
\text { Riesenbärenklaus“ zur „Entfernung des Riesenbärenklaus nur in } \\
\text { Einzelfallen“ }\end{array}$ & $(-) 0,158^{*}$ & $(-) 8,96$ \\
\hline Kostenattribut (Sonderabgabe pro Person/Jahr) & $-0,017 * * *$ & - \\
\hline
\end{tabular}

Die höchste marginale Zahlungsbereitschaft von $25,71 €$ wurde für die ökosystemare Vorsorgeleistung der Waldbiodiversität gegen Schädlinge und Windwurf (z.B. Verbesserung der "mittleren Widerstandskraft gegen Schädlinge und Stürme" zu der Ausprägung "hohe Widerstandskraft gegen Schädlinge und Stürme") ermittelt. An zweiter Stelle folgt die ökosystemare Vorsorgeleistung der Waldbiodiversität vor Gefahren durch Klimaveränderungen mit 20,01 € (z.B. Verbesserung der „Kohlenstoff-Bindung der 


\section{Chapter II}

Emissionen von 540 Personen“ zu der Ausprägung „Kohlenstoff-Bindung der Emissionen von 630 Personen“). Für die ökosystemare Vorsorgeleistung der Waldbiodiversität vor neuen unbekannten Gefährdungen ist eine marginale Zahlungsbereitschaft von $15,71 €$ ermittelt worden (z.B. Veränderung der "mittleren Widerstandskraft gegen unbekannte Gefahren” zu der Ausprägung "hohe Widerstandskraft gegen unbekannte Gefahren"). Für den Schutz vor Gefahren durch nicht-einheimischen Pflanzen wurde eine marginale Zahlungsbereitschaft von $8,96 €$ ermittelt. Dabei bezieht sich die Zahlungsbereitschaft auf die gewünschte Veränderung der „regelmäßigen großflächigen Entfernung des Riesenbärenklaus“ zur der weniger radikalen Ausprägung „Entfernung des Riesenbärenklaus nur in Einzelfällen“.

$\mathrm{Da}$ es für die meisten Umweltgüter und ökosystemaren Dienstleistungen keinen Markt gibt, ist es eine Herausforderung, ihren ökonomischen Nutzen für die Gesellschaft abzuschätzen. Politiker und Entscheidungsträger benötigen jedoch diese Informationen über öffentliche Präferenzen, z.B. im Hinblick auf den Klimawandel, um Umweltprogramme zu planen und umzusetzen. Zudem sieht Art. 11 der Biodiversitätskonvention vor, dass jede Vertragspartei Anreizmaßnahmen beschließt, die der Erhaltung und nachhaltigen Nutzung der Biodiversität dienen. Hierzu leisten Zahlungsbereitschaftsanalysen zu Umweltgütern und ökosystemaren Dienstleistungen einen wichtigen Beitrag, denn sie dienen zur ökonomischen Dimensionierung solcher Schutzmaßnahmen.

\section{Literaturverzeichnis}

Adamowicz WL, Boxall P, Williams M, Louviere J (1998) Stated Preference Approaches for measuring passive use values: Choice Experiments and Contingent Valuation.

American Journal of Agricultural Economics 80:64-75

Arrow K, Solow R, Portney PR, Learner EE, Radner R, Schuman H (1993) Report of the NOAA Panel on Contingent Valuation. Resources for the Future, Washington D.C.

Barkmann J, Cerda C, Marggraf R (2005) Interdisziplinäre Analyse von Naturbildern: 
Chapter II

Notwendige Voraussetzung für die ökonomische Bewertung der natürlichen Umwelt. Umweltpsychologie 9:10-29

Hensher D, Rose J, Greene W (2005) Applied choice analysis: a primer. Cambridge University Press, Cambridge

Kowarik I (2003) Biologische Invasionen. Neophyten und Neozoen in Mitteleuropa. Ulmer, Stuttgart

Loreau M, Naeem S, Inchausti P, Bengtsson J, Grime JP, Hector A, Hooper DU, Huston A, Reffaelli D, Schmid B, Tilman D, Wardle DA (2001) Biodiversity and Ecosystem Functioning: Current Knowledge and Future Challenges. Science 294:804-808 McCann KS (2000) The diversity-stability debate. Nature 405:228-233

Tilman D, Wedin D, Knops J (1996) Productivity and sustainability influenced by biodiversity in grassland ecosystems. Nature 379:718-720

Yachi S, Loreau M (1999) Biodiversity and ecosystem productivity in a fluctuating environment: the insurance hypothesis. Proceedings of the National Academy of Sciences of the U.S.A. 96:1463-1468 


\section{Chapter III}

\section{Forest-management measures to mitigate climate change or to adapt to its effects: monetary preferences in the user community around Hainich National Park, Germany*}

\section{Sandra Rajmis, Jan Barkmann, Rainer Marggraf}

Abstract: In contemporary media discourse, suggestions for publicly mandated climate change mitigation or adaptation measures are frequently challenged from a cost perspective. However, empirical data on the actual economic appreciation of local mitigation and adaptation measures expressed as citizen willingness-to-pay (WTP) are scarce. In this paper, we report results of a stated preference survey using a Choice Experiment (CE) that quantifies economic preferences for biodiversity-based climate change mitigation and adaptation in the region surrounding Hainich National Park (Thuringia, Germany). A representative sample of 302 respondents - the majority of them frequent Hainich forest visitors - was interviewed face-to-face in autumn 2006. Nested Logit analysis shows that residents state a substantial positive WTP for climate change mitigation by afforestation $(\mathrm{p}<0.001)$. If converted to WTP for an additional sequestration of carbon that average German citizens emit as $\mathrm{CO}_{2}$, a monetary value of $7.34 € \mathrm{tC}^{-1} \mathrm{a}^{-1}$ is obtained. For increasing forest resistance and resilience against insect pests and storms (climate change adaptation) a WTP of $27.54 € \mathrm{a}^{-1}(\mathrm{p}<0.001)$ is obtained, and of $16.83 € \mathrm{a}^{-1}(\mathrm{p}<0.001)$ for increasing the 'general' resilience and resistance of forest ecosystems to environmental stressors. Respondents support only moderately aggressive programs to eradicate invasive plants. Due to the lack of comparable studies, it

\footnotetext{
* The manuscript has been accepted for publication in 'Climate Research'
} 
should conservatively be assumed that WTP is lower if mitigation and adaptation measures were to be implemented in forests not or only rarely used by local respondents. As all proposed means for climate change mitigation and adaptation contribute to local forest ecosystem biodiversity, the study argues for realizing win-win potentials between climate policy and regional conservation concerns.

Keywords: Economic valuation, choice experiment, willingness-to-pay, afforestation, insect pests, climatic extremes, ecosystem, resilience, biological diversity

\section{Introduction}

A very substantial body of scientific evidence indicates that the Earth's climate is rapidly changing, mainly as a result of increasing anthropogenic greenhouse gas emissions (e.g., Bernstein et al. 2007, Ruddiman et al. 2005, Levitus et al. 2000). Internationally influential political actors frequently question the expediency of the Kyoto Protocol and other suggested climate change mitigation targets that require substantial reductions of green house gas (GHG) emissions. Political standard rhetoric usually cites economic reasons, e.g., claiming that more ambitious measures would "cause serious harm to the U.S. economy" (Bush 2001, EIA 2002). In contrast, Stern (2006) claims that the costs of action need not be prohibitive, and would be much smaller ( $1 \%$ of GDP) than the damage of climate change (5-20\% GDP) under high emissions scenarios several decades from now. The Stern review itself has been criticized on multiple counts (e.g., Tol 2007, Nordhaus 2007, Cole 2007). Particularly in the case of conflicting macroeconomic projections, we may safely assume that the willingness of political decision-makers to enact costly climate protection measures is influenced by evidence regarding if and how much consumers and citizens ('voters') are actually willing to pay for such measures. Surprisingly few willingness-to-pay (WTP) studies are available 
(Table 1). However, an improved integration of economic and social science expertise in climate research is critically called for (Msangi et al. 2006).

In this paper, we present results of a survey conducted in several villages and two smaller towns around Hainich National Park (Thuringia, Germany). The results document a substantial WTP for different types of additional regional climate change mitigation and adaptation. We first explain the main methodological features of the used choice experiment (CE) method and its analysis (sections 2 and 3). Empirical results and WTP estimates follow in section 4 , and are discussed in section 5 .

\section{Methods}

\subsection{The Choice Experiment}

The CE method is based on the Characteristics Theory of Value (Lancaster 1966) and on Random Utility Theory (McFadden 1973, Adamowicz et al. 1998a). CEs were initially developed in marketing research to estimate economic preferences for characteristics (attributes) of new products. They have proven to be a versatile method for the estimation of economic values regarding the environment (Hensher et al. 2005). CEs rely on social science surveys for data gathering as does the related contingent valuation method. Instead of asking questions such as "Are you willing to pay $\mathrm{X} €$ to prevent $\mathrm{Y}$ effect of climate change?", CEs focus on trade-offs among different policy scenarios with different environmental outcomes.

CEs have been recognized to be particularly suitable to analyze different options for mitigation of and adaptation to climate change (Australian Greenhouse Office 2004:19). 


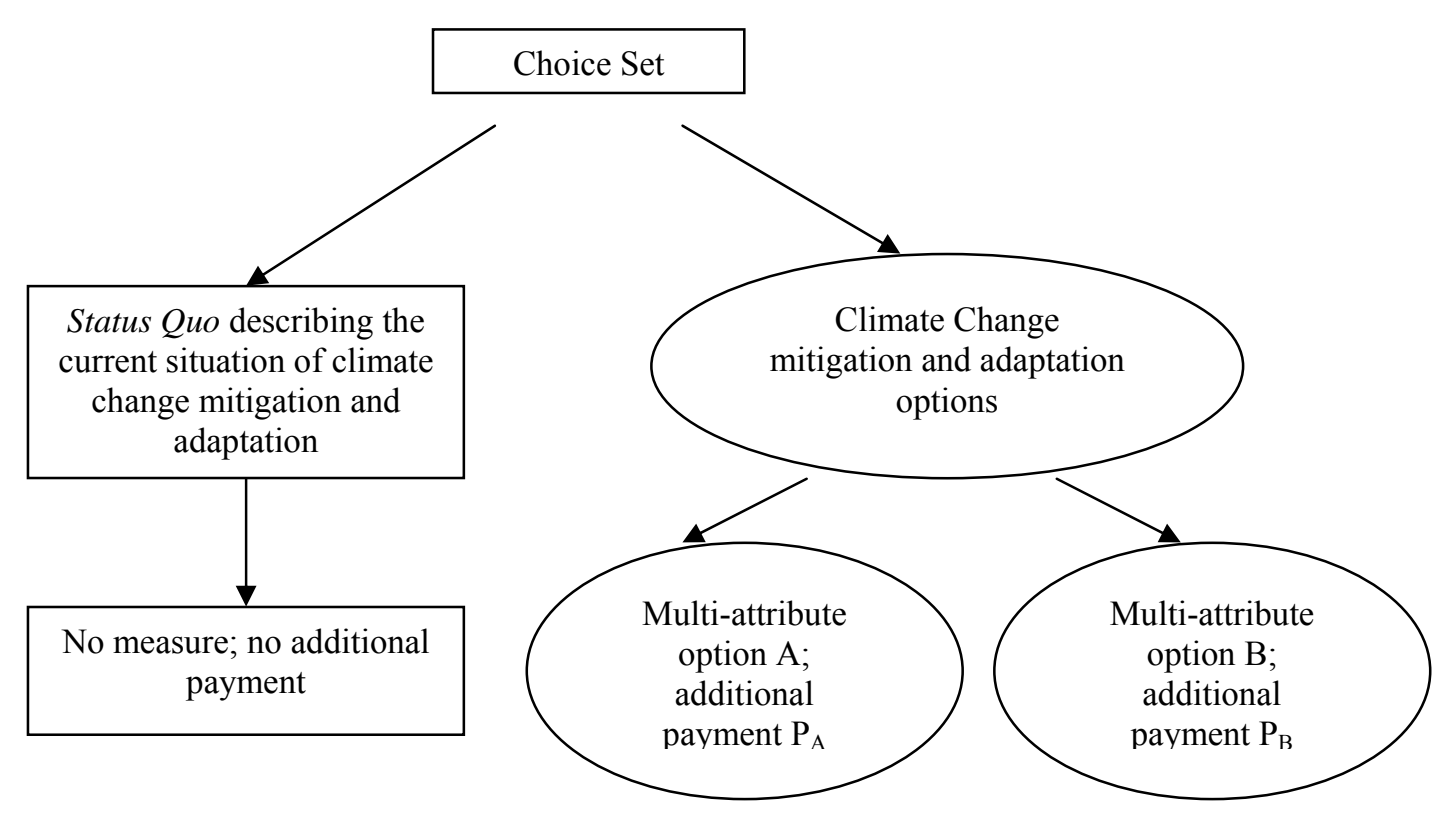

Figure 1. Structure of the Choice Experiment: a choice set with one status quo option and two multi-attribute climate change mitigation and adaptation options are presented to respondents

The different choice scenarios ('options') of a CE differ in the levels that a small number of attributes (= characteristics) of the policy scenarios take. In CE face-to-face applications, the scenarios are often printed on cardboard cards, and presented to respondents. We confronted respondents with three of these cards (the choice set; Figure 1), and asked to choose the option they want to see implemented. Two cards characterise the generic policy options A and B, and a third card represents the current situation (Status Quo). The "price" of each policy option is included as one attribute on the choice cards (cost attribute). Often the cost attribute is operationalised as a mandatory tax payment. For the Status Quo card, the cost is always zero. The specific combination of attribute levels on the cards is determined by experimental design rules ${ }^{13}$. Some more details on the econometric estimation of CE models are given in section 3.1 .

13 This procedure results in a few choice cards that may appear implausible because they request an 


\section{Chapter III}

Table 1. Case studies attempting to estimate the societal value of global warming, climate change mitigation or adaptation

\begin{tabular}{|c|c|c|c|}
\hline Study & Object of valuation & Monetary value estimation $\$[\$ / €]$ & Remarks \\
\hline $\begin{array}{l}\text { Zelek \& } \\
\text { Shively (2003) }\end{array}$ & $\begin{array}{l}\text { Marginal costs for } \\
\text { carbon storage }\end{array}$ & $\begin{array}{l}3.30 \$(2.25 €) \text { to } 3.90 \$(2.65 €)[\mathrm{tC}] \\
\text { (depending on site quality and term } \\
\text { between } 122 € / \mathrm{tC} / \mathrm{yr} \text { and } 437 \\
€ / \mathrm{tC} / \mathrm{yr} \text { ) }\end{array}$ & $\begin{array}{l}\text { Marginal costs for C storage on } \\
\text { fallow land used for forestry or } \\
\text { agroforestry }\end{array}$ \\
\hline $\begin{array}{l}\text { Berk \& } \\
\text { Forvell (1999) }\end{array}$ & $\begin{array}{l}\text { Prevention of } \\
\text { significant climate } \\
\text { change }\end{array}$ & $\$ 13.70(9.33 €)[\mathrm{WTP} /$ person/yr] & $\begin{array}{l}\text { Winter and summer climate } \\
\text { scenarios were presented to } \\
\text { respondents }\end{array}$ \\
\hline $\begin{array}{l}\text { Reiner et al. } \\
(2006)\end{array}$ & $\begin{array}{l}\text { "Solving" global } \\
\text { warming }\end{array}$ & $\begin{array}{l}\$ 50(34 €)[\mathrm{WTP} / \text { person/month] } \\
(408 € / \text { person/yr) }\end{array}$ & $\begin{array}{l}\text { Study was conducted in four } \\
\text { different countries (Japan, the U.S., } \\
\text { Britain, Sweden) }\end{array}$ \\
\hline $\begin{array}{l}\text { Viscusi \& } \\
\text { Zeckhauser } \\
(2006)\end{array}$ & $\begin{array}{l}\text { Avoidance of global } \\
\text { warming } \\
\text { for a } 30 \text {-year period }\end{array}$ & $\begin{array}{l}0.50 \$(0.32 €)[\mathrm{WTP} / \text { gallon }](140 \\
€ / \mathrm{tC} \text { or } 170 € / \text { person/yr })\end{array}$ & $\begin{array}{l}\text { Respondents were asked to } \\
\text { suppose that scientists develop } \\
\text { technologies that eliminate all } \\
\text { climate change problems by the } \\
\text { year } 2024 \text {. }\end{array}$ \\
\hline $\begin{array}{l}\text { Alavalapati et } \\
\text { al. (2004) }\end{array}$ & $\begin{array}{l}\text { Additional C } \\
\text { sequestration by } \\
\text { silopasture }\end{array}$ & $\begin{array}{l}\$ 58.05(39.51 €) \text { to } \$ 62.72(42.69 €) \\
{[\mathrm{WTP} / \text { household/per year for a total }} \\
\text { of five years] }\end{array}$ & $\begin{array}{l}\text { Also valuated: water quality and } \\
\text { wildlife habitats associated with } \\
\text { silvopasture }\end{array}$ \\
\hline $\begin{array}{l}\text { Rajmis \& } \\
\text { Barkmann } \\
\text { (this study) }\end{array}$ & $\begin{array}{l}\text { Climate change } \\
\text { mitigation by } \\
\text { afforestation }\end{array}$ & $\begin{array}{l}7.34 € \\
{[\mathrm{WTP} / \mathrm{tC} \text { emitted/person/yr] }}\end{array}$ & $\begin{array}{l}\text { Calculated from } 20.01 € / \text { person } / \mathrm{yr} \\
\text { tax increase for one level increase } \\
\text { in afforestation (cf. Table 2) }\end{array}$ \\
\hline
\end{tabular}

$\$$ All $\$$ values were converted to euros at exchange rate $\$=0.68 €$.

\subsection{The study site}

All mitigation and adaptation scenarios in this paper were to take place in the Hainich area in Thuringia. The area includes Hainich National Park (Hainich NP) having 7,600 ha, and the wider Hainich forest ecosystem having about 16,000 ha. It is the largest coherent deciduous forest in Germany. The National Park is currently being used for recreation, tourism and partly just as natural habitat. Hainich NP is dominated by Fagus sylvatica L. (European Beech), mostly in uneven-aged stands that have not been harvested, thinned or used at least since 1997. During the previous 32 years, the forest was part of a military training area where only a few single trees of high value were cut (Mund 2004).

additional tax payment although the environmental attributes look worse than the Status Quo (see Tab. 3). However, because respondents are always free to choose the Status Quo card at zero cost, the choice set always offers meaningful choices. 


\section{Chapter III}

Nevertheless, it has to be kept in mind that the unmanaged sites do not represent a primary forest because nearly all forests in central Europe are influenced by forest use and management. The managed areas of the Hainich forest had to be part of a shelterwood or a selection system for at least 140 years (equivalent to a rotation period) ${ }^{14}$ (Mund 2004). For the Hainich forest ecosystem, yearly average net carbon uptake as high as $480-580 \mathrm{~g} \mathrm{C} \mathrm{m}^{-2} \mathrm{a}^{-1}$ was calculated (Knohl et al. 2003). Only a fraction of this can be attributed to long-term soil storage. Timber carbon pools are similar to literature values for primary beech stands under favourable conditions (Korpel 1995, Meyer et al. 2003). Generally, regenerated forests store less carbon than natural forests, even at maturity (Buchmann \& Schulze 1999).

\subsection{Measures of climate change mitigation and adaptation}

In order to make sure that respondents properly understood the climate change mitigation and adaptation policy scenarios, we employed two strategies. First, we devoted 16 semi-structured in-depth interviews to an elucidation of the mental 'images' that typical respondents hold on issues such as climate change, risks from increasing weather anomalies, invasive species and environmental risks in general (Rajmis \& Barkmann 2007). Second, we made sure that any mitigation or adaptation attribute makes sense to respondents in terms of their personal values and interests. By explicating the benefits that respondents obtain from an implementation of the proposed mitigation and adaptation options, we used an ecosystem service approach developed specifically for the valuation of 'unfamiliar' environmental attributes (Barkmann et al. 2008). In this approach, the focus shifts from a valuation of technically described changes in ecosystem structure or functioning (or the measures that bring about these changes) to the valuation of ecosystem service effects, i.e. benefits to people.

\footnotetext{
${ }^{14}$ All silvicultural treatments carried out within the last 140 years, including the timing of activities, were typical for the specific silvicultural system and for beech forests on fertile soils (Mund 2004)
} 
Table 2. Climate change mitigation and adaptation measures/indicators used in the Choice Experiment (translated from German questionnaire version)

\begin{tabular}{|c|c|c|c|}
\hline Attribute & Measure/Indicator & \multicolumn{2}{|c|}{$\begin{array}{l}\text { Level of change of mitigation or adaptation measure/indicator } \\
\text { (Coding in parenthesis if not directly given; *: Status Quo) }\end{array}$} \\
\hline \multicolumn{4}{|c|}{ Climate change mitigation } \\
\hline Afforestation & $\begin{array}{l}\text { Afforestation } \\
\text { quantified by carbon } \\
\text { sequestration/emission } \\
\text { equivalent per capita }\end{array}$ & $\begin{array}{l}\text { Sequestration/emission } \\
\text { equivalent of } 540 \\
\text { persons* }(540)\end{array}$ & $\begin{array}{ll}\begin{array}{l}\text { Sequestration/emission } \\
\text { equivalent of }\end{array} & \begin{array}{l}\text { Sequestration/emission } \\
\text { equivalent of }\end{array} \\
630 \text { persons }(630) & 720 \text { persons }(720)\end{array}$ \\
\hline \multicolumn{4}{|c|}{ Climate change adaptation } \\
\hline $\begin{array}{l}\text { Invasive } \\
\text { plants }\end{array}$ & $\begin{array}{l}\text { Removal of invasive } \\
\text { non-native plants }\end{array}$ & $\begin{array}{l}\text { Only if harmful and in } \\
\text { particular cases }(1)^{*}\end{array}$ & $\begin{array}{l}\text { Large scale removal } \\
\text { if harmful or not (2) }\end{array}$ \\
\hline $\begin{array}{l}\text { Pests and } \\
\text { storms }\end{array}$ & $\begin{array}{l}\text { Planting of better site- } \\
\text { adapted tree species }\end{array}$ & $\begin{array}{l}\text { Low resistance and } \\
\text { resilience (1) }\end{array}$ & $\begin{array}{ll}\text { Medium resistance and } & \text { High resistance and } \\
\text { resilience }(2)^{*} & \text { resilience (3) }\end{array}$ \\
\hline $\begin{array}{l}\text { General } \\
\text { forest } \\
\text { ecosystem } \\
\text { resilience }\end{array}$ & $\begin{array}{l}\text { Changes in the } \\
\text { diversity of } \\
\text { mycorrhizal fungi }^{\$}\end{array}$ & $\begin{array}{l}\text { Low resistance and } \\
\text { resilience (1) }\end{array}$ & $\begin{array}{ll}\text { Medium resistance and } & \text { High resistance and } \\
\text { resilience } & \text { resilience (3) } \\
(2)^{*} & \end{array}$ \\
\hline $\begin{array}{l}\text { Cost } \\
\text { attribute } \\
(, \text { price“") }\end{array}$ & $\begin{array}{l}\text { Income change per } \\
\text { month/person by a } \\
\text { dedicated tax }\end{array}$ & \multicolumn{2}{|c|}{$0 € *, 5 €, 10 €, 20 €, 35 €, 50 €, 60 €, 80 €$ (=coding) } \\
\hline
\end{tabular}

\subsubsection{Mitigation: Additional carbon sequestration by afforestation}

Pre-study interviews revealed that respondents did not consider tons of sequestered carbon per year as a meaningful quantification of a climate change mitigation attribute brought about by a forest ecosystem. If explained in terms of their own annual $\mathrm{CO}_{2}$ emissions $(\sim 10 \mathrm{Mg} \mathrm{CO} 2$ person $^{-1} \mathrm{a}^{-1}$ in Germany), however, respondents could relate much more easily to a quantitative aspect of climate change mitigation measures. This result led us to focus explicitly on individual contributions towards climate change mitigation. Thus, we decided to elicit preferences quantified in terms of per person $\mathrm{CO}_{2}$ emission equivalents. Although climate change is a global issue, the regional scope of our study prompted us to search for Hainich forest-based measures that could serve as 'vehicles' to effectuate climate change mitigation. In the following we describe the scientific basis for the quantification of the respective $\mathrm{CE}$ attribute levels on regional afforestation measures. 
First, the C-sequestration of the existing forest had to be assessed. Robertson and Vitousek (1981) found a long term sequestration rate of $9.4 \mathrm{~g} \mathrm{C} \mathrm{m}^{-2} \mathrm{a}^{-1}$ for the soil compartment of a 250-year-old oak forest. Much lower values $2.4 \mathrm{~g} \mathrm{C} \mathrm{m}^{-2} \mathrm{a}^{-1}$ for a 200 -yearold oak-hickory-pine stand (Switzer et al. 1979) as well as much higher values 60-80 g C m${ }^{-2}$ $\mathrm{a}^{-1}$ for an 80-year-old stand (Jenkinson 1971) have been reported in old field succession. In absence of more detailed long-term C-sequestration rates for Hainich forest, we adopted a rate of $9.2 \mathrm{~g} \mathrm{C} \mathrm{m}^{-2} \mathrm{a}^{-1}$, i.e. slightly lower that the rate determined by Robertson and Vitousek (1981). For roughly 16,000 ha of Hainich forest, this results in annual C-sequestration equivalent to the emissions of 540 average German citizens (for calculation, see annex).

As alternatives to the Status Quo, we offered respondents two different local afforestation measures: one that results in the sequestration of the $\mathrm{CO}_{2}$ emitted by additional 90 individuals (level 1; resulting sequestration of 630 individuals), and one that sequesters twice as much more (level 2; resulting sequestration of 720 individuals). At C-sequestration rates typical for young aggrading forests $\left(6.2 \mathrm{t} \mathrm{CO}_{2} \mathrm{ha}^{-1} \mathrm{a}^{-1}\right.$; Deckmyn et al. 2004) around 145 ha afforestation area would be required for a level 1 measure, and 290 ha for level 2 (for calculation, see annex). The size of these two afforestation measures seems somewhat arbitrary. The values were chosen (i) to convey the idea that a substantial improvement of Csequestration of Hainich forest could be achieved, but (ii) without requiring areas of land so extensive as to cause potentially negative emotional reactions.

For a calculation of the shadow price of $\mathrm{C}$-sequestration, we first calculate the 'marginal' WTP for a one level change in the afforestation attribute per respondent. Because of the strategy to relate preferences for $\mathrm{C}$ sequestration to personal emissions i.e. to individual responsibility for climate change this $\mathrm{mWTP}$ is then attributed to the individual average annual $\mathrm{C}$ emission of about $2.7 \mathrm{t} \mathrm{C} \mathrm{a}^{-1}$. 


\subsubsection{Adaptation: Removal of potentially invasive plants}

Several invasive species are likely to benefit from expected global climate change trends (Rejmanek 2000). Invasive plants are regarded as the second largest threat to biodiversity in Central Europe (Kowarik 2003). Besides competing with native species for habitats and resources, invasive species can harm forestry and agriculture. The giant hogweed Heracleum mantegazzianum, e.g., is a host for the crop pathogen Sclerotina sclerotina (Williamson \& Forbes 1982), can reduce species richness of invaded habitats by 40 \% (Pyšek \& Pyšek 1995), and is known to produce human-toxic substances in its sap (Jaspersen-Schip et al. 1996).

Our pre-study showed that respondents felt threatened by non-native plants, particularly by the giant hogweed. Thus, we decided to use Heracleum mantegazzianum to explain risks of invasive plants. The two attribute levels included are:

- Level 1: removal of invasive plants in particular cases for which negative effects are known, or

- Level 2: removal of invasive plants across large areas even if it is unclear if they have negative effects or not.

Level 1 represents current practice (Status Quo). We had no a priori hypothesis if level 2 constitutes, on average, a utility gain as compared to the Status Quo.

\subsubsection{Adaptation: Increasing forest resistance and resilience in the face of pests and storms} Geographical shifts in the area of pests and diseases can result from climate change (Parmesan 2006). One example is the mountain pine beetle (Dendroctonus ponderosae) living in the Rocky mountain range of the United States which now only takes one year per generation rather than its previous two years life cycle (Logan et al. 2003). This, in turn, can increase infestation rates with the pine blister rust fungus (Cronartium ribicola). Also wind storm related risks rise for German forests (Zebisch et al. 2005:6). Stochastic dynamic models 
provide evidence that asynchronicity of species responses can ensure that species-rich forest ecosystems provide climate change adaptation services because they are able to adjust better to the changing environmental conditions (cf. Yachi \& Loreau 1999).

Our qualitative interviews revealed that respondents perceived forests as threatened by insect pest outbreaks, particularly by bark-beetles (Scolytida spp.), 'caterpillar' damages, and storm events. We bundled these rather well-known threats into one attribute on forest resistance and resilience ("Widerstandskraft") to pests and storms. Indicating that this is a simplification of a more complex ecological reality, we explained that better resistance and resilience could be effectuated by higher diversity of site-adapted tree species.

We offered three attribute levels ranging from 'high resistance and resilience' to insect pests and storms by planting additional site-adapted tree species, to a 'low resistance and resilience' level characterised by low diversity of site-adapted tree species. In the project region, several monoculture forest tree plantations exist, where respective 'diversification measures' could be implemented.

\subsubsection{Adaptation: Increasing 'general' forest ecosystem resistance and resilience}

Because not all risks of climate change are apparent today, biological insurance services in the face of new, fundamentally uncertain or unknown risks (Barkmann \& Marggraf 2007, Rajmis et al. 2008) are called for. Thus, we included an attribute on increasing 'general' forest ecosystem resistance and resilience. The German Advisory Council on Global Change (WBGU 1999) suggests a precautionary risk management strategy to handle as yet undiscovered risks. In an often implicit form, this argument is used when ecologists and environmental economists suggest preserving as many species as possible hoping for an ecological insurance effect (Myers 1996, Gitay et al. 1996, Edwards \& Abivardi 1998, Yachi \& Loreau 1999, Perrings 1995). From an ecosystem science perspective, species diversity 


\section{Chapter III}

provides key information on the processing of matter and energy within an ecosystem, and is an indispensable factor of the capacity of the ecosystem to self-organise in the face of internal or external changes (Kutsch et al. 2001).

Soil organisms are essential for the fundamental functioning of terrestrial ecosystems (e.g., Balser et al. 2002, 265). One group of species whose diversity has been linked to the stability properties of forest are mycorrhiza species (Bot \& Benites 2005). Mycorrhizal fungi play a key role in the uptake of nutrients and water (Galvan et al. 2007), and contribute to the maintenance of soil porosity and organic matter content (Dighton 2003).

We chose a measure of soil organism diversity to indicate the capacity of the Hainich forests to self-organise and, thus, to provide 'general' forest ecosystem resistance and resilience over other biota because soil organisms are not visible. Changes in tree or herb diversity, for example, may have triggered the statement of additional aesthetic preferences in our non-expert respondent sample. This would have made it more difficult to interpret WTP statements for an attribute on general forest resilience. Interviewers briefly explained the importance of the mycorrhiza, and its role for generalised ecosystem resilience and resistance in the face of as yet unknown environmental threats. Furthermore, we mentioned that forest thinning may improve mycorrhiza numbers, and without being specific about improvement measures explained that stands with lower mycorrhizal diversity exist where mycorrhizal diversity could be fostered.

We offered three levels to respondents: High, medium and low 'resistance and resilience' to unknown threats. The attribute level description on the choice only includes this quantification. It does not mention the mycorrhiza indicator nor any hint at potential forestry measures (see Fig. 2).

Changes between levels are difficult to bring about by traditional forestry measures for many forests. Still, mycorrhizal diversity responds to changes in forest structure (Kernaghan 
et al. 2003), at least partly to inoculation in afforested stands (Menkis et al. 2007), and changes in atmospheric carbon inputs (Talbot et al. 2008). Because we restrict the interpretation of the attribute to adaptive ecosystem insurance services (see also Rajmis et al. subm.), the principal manageability of mycorrhizal diversity suffices to justify the utilisation of mycorrhizal diversity as a plausible indicator of positive biodiversity effects on 'general' forest resistance and resilience. Although few respondents were knowledgeable about the importance of tree-mycorrhiza interactions, our extensive pre-studies had clearly shown that the role of functional diversity and functional redundancy for ecological insurance (McCann 2000) was familiar to respondents if described in non-technical terms (Rajmis \& Barkmann 2007).

\subsection{Preparation and administration of the CE study}

From attributes and attribute levels (Tab. 2), we generated an orthogonal main effects design (Hensher et al. 2005:115) with 64 combinations of different choice cards that were assigned to 32 eight choice sets using the mix and match procedure by Chrzan \& Orme (2000). The 32 choice cards were, in turn, randomly assigned to four blocks of eight choice sets. Interviewers alternated blocks systematically with each consecutive respondent being assigned to the choice sets of one block.

The CE main survey $(n=302)$ was preceded by qualitative preliminary studies $(n=16$; Rajmis \& Barkmann 2007), pre-test interviews $(n=57)$, and a pilot study $(n=106)$. Pilot study and main study were conducted as a household survey using face-to-face interviews in 19 of the 30 villages adjacent to Hainich National Park $\left(10^{\circ} 27^{\prime} 45^{\prime \prime} \mathrm{E}, 51^{\circ} 4^{\prime} 48^{\prime \prime} \mathrm{N}\right)$, and in the neighbouring towns of Eisenach (43,300 citizens) and Bad Langensalza (18,390 citizens) (Thuringia). To sample private households, we used the random route method (Kromrey 2006). For the random route, interviewers are given exact points of departure in a certain 


\section{Chapter III}

street beginning with a defined starting point, e.g. rules about the direction to walk, which bell to ring on their way, how to behave at crossroads and other details on establishing contacts to survey participants.

Target respondents were all German speaking individuals who were at least 18 years of age by the day of the interview. Target persons were identified by the 'last-birthday' method, which means that the person with the most recent birthday was sampled (Rizzo et al. 2004). All interviews (pilot and main study) were conducted by five well-trained university students.

471 contacted target respondents denied giving an interview. Of all successfully contacted 302 households, 282 respondents completed the choice task. 20 respondents $(6.6 \%)$ protested the choice experiment (see Adamowicz et al. 1998b:68). Eleven of these protested against the cost attribute (rejection of any extra tax, extremely skeptical attitude towards implementation of the proposed measures). Furthermore, three respondents refused any measure involving (strongly disliked) Hainich National Park, while another two respondents had a strict non-interference attitude towards the National Park. Only two respondents protested the proposed mitigation and adaptation measures themselves. Finally, two individuals clearly did not understand the choice task. An average interview took 35 minutes. In addition to a suite of attitudinal questions not included in this paper (Rajmis et al. 2008), we asked respondents to rate the importance of the CE attributes explicitly ("most important $=$ 5' to 'completely unimportant $=1$ '). The rating is reported in Figure 4. 

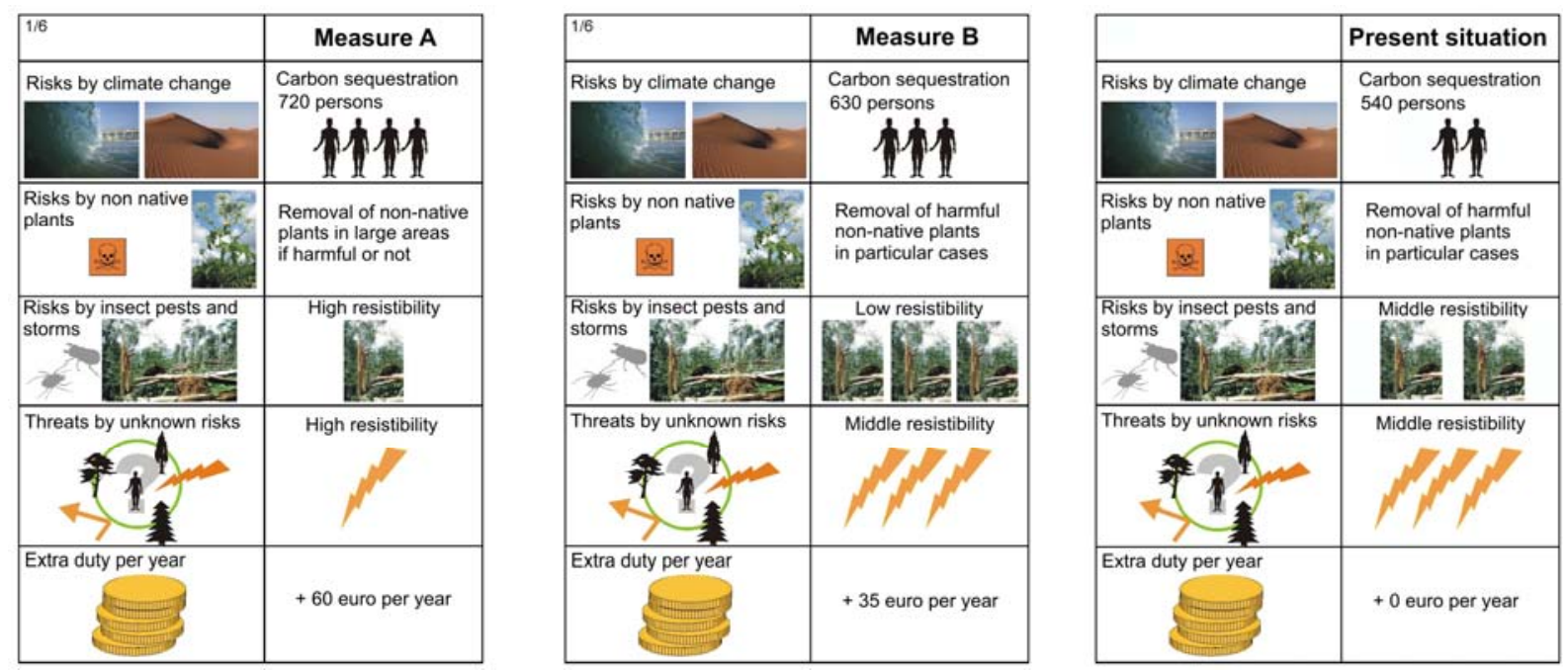

$\square \quad$ I would chose Measure A

$\square \quad$ I would chose Measure B

I would chose "the present situation" (non of the measures)

Figure 2. A set of sample choice cards (translated from the original German language version), "Widerstandskraft" was translated short as "resistibility" here

\section{Econometric analysis}

We assume an additive utility function linear in parameters with respect to the attribute levels as coded in Table 2 (see also section 2.1). The utility function can be separated into an observable component $\mathrm{V}_{\text {in }}$ and unobservable (error) component $\varepsilon_{\text {in }}$ :

$$
\mathrm{U}_{\text {in }}=\mathrm{V}_{\text {in }}+\varepsilon_{\text {in }}
$$

where $U_{\text {in }}$ is the total utility of alternative $i$ for individual $n$. The probability that individual $n$ will choose option $i$ over option $j$ within the complete choice set $\mathrm{C}$ is given by:

$$
\operatorname{Pr}_{\text {in }}=\operatorname{Pr}\left(V_{\text {in }}+\varepsilon_{\text {in }}>V_{\text {jn }}+\varepsilon_{\text {jn }}, \text { all } j \in C\right)
$$

If a deterministic utility component $V_{1}$ is hypothesized to be a linear function of attribute $Z_{1}$ itself, plus an interaction term of the attribute $Z_{1}$ with an individually varying sociodemographic variable $A, \mathrm{~V}_{1}$ can be expressed as

$$
\mathrm{V}_{1}\left(Z_{1}, A\right)=c_{A} * Z_{1} * A+c_{1} * Z_{1}
$$




\section{Chapter III}

with $c_{A}$ : utility coefficient of the interaction term (Barkmann et al. 2007). In the econometrically estimated utility models, a positive sign of the coefficients $c$ indicates a positive influence of the respective term on choices, and thus on utility. To reduce colinearity between the interaction term and the non-interacted attribute term, the socio-demographic variable $A$ can be standardized before multiplied with $Z_{1}$. The vector of utility coefficients is usually estimated with maximum likelihood estimation techniques. The estimated choice models include an alternative specific constant (ASC) that picks up systematic differences in choice patterns between the three choice cards. The ASC was coded 'zero' for cards A and B, and '1' for the Status Quo option (Status Quo-ASC).

Preliminary analyses unveiled a risk of violation of the independence from irrelevant alternatives (IIA) assumption necessary for the application of the (simple) Conditional Logit model. Thus, Nested Logit models (NL) were used that partially relax the IIA assumption (Train 1998, Hensher et al. 2005:518). Suitable NL model structures were identified, and the corresponding models estimated with NLOGIT 3.0. The inclusive value was set to 1.0 for the degenerated branch, and the model initiated with starting values obtained from a non-nested NL model (Hensher et al. 2005:530). All scale parameters were normalized at the lowest level (RU1). As model statistics, we report adjusted pseudo- $R^{2}$ values in relation to a 'constants only' model. Values between 0.06 and 0.07 correspond to $R^{2}$ values of 0.19 and 0.22 in their ordinary least squares equivalents (Hensher et al.2005:338).

To test for influences of socio-demographic variables on choices, interaction terms of the ASC and of the climate change mitigation attribute were generated (Table 5). The improved model was generated stepwise by initially including all statistically significant interaction terms from single interaction models and then deleting non-significant interaction terms one-by-one. Significant interaction terms of socio-demographic variables and the climate change mitigation attribute are presented in the improved model (Table 5). 


\subsection{Willingness-to-pay calculation}

Statistically significant attribute coefficients allow for the calculation of respondent WTP for attribute level changes. For attributes linear in parameters, marginal WTP equals the negative ratio of the respective attribute coefficient $c_{z}$ and the coefficient of the monetary attribute $c_{y}$ :

$\mathrm{mWTP}=-\frac{c_{z}}{c_{y}}$

All WTP values given in Tab. 4 refer to a 'marginal' one-level change in the attributes (mWTP). For the 20 respondents $(6.62 \%$ of interview respondents) protesting the choice experiment, '0' mWTP was assumed.

\section{$4 \quad$ Empirical results}

\subsection{Socio-demographic characteristics of respondents}
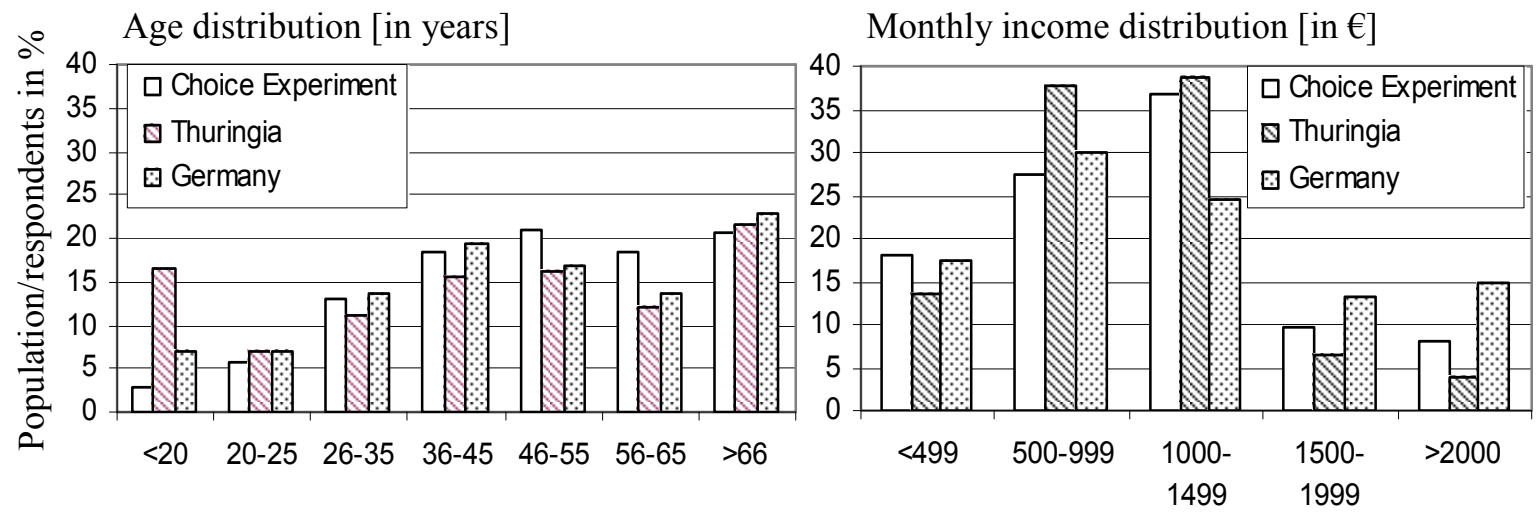

Figure 3. Age and income distribution of population and respondents ${ }^{15}$

\footnotetext{
15 Data of own survey on the left $(\mathrm{n}=282)$, of Thuringia in the middle (Thüringer Landesamt für Statistik 2008), and of Germany on the right side (Statistisches Bundesamt 2008)
} 


\section{Chapter III}

The gender ratio of respondents is 49:51 (women: men; Table 3). The youngest respondent was 18 years old, the oldest 92 . The majority of respondents $(45 \%)$ holds a secondary school certificate, and receives a salary (47\%). Average monthly net-income is $1,125 €$ per person. Socio-demographic key variables are close to state and national averages (Figure 3; Thüringer Landesamt für Statistik 2008, Statistisches Bundesamt 2008). 86\% of respondents have been at Hainich National Park at least once. On average, respondents visit the national park 14 times per year.

Table 3. Socio-demographic characteristics of respondents

\begin{tabular}{|c|c|c|}
\hline Variable & Description & Results (standard deviation in parenthesis) \\
\hline Gender & $\begin{array}{l}\text { Dummy variables describing gender of respondents } \\
\text { [0: female; } 1: \text { male] }\end{array}$ & $\begin{array}{l}49 \% \text { women } \\
51 \% \text { men }\end{array}$ \\
\hline Age & Age in years & $50.27(16.95)$ [between 18 and 92] \\
\hline Education & $\begin{array}{l}5 \text { point score to describe attainted formal } \\
\text { educational level } \\
\text { [1: None; } 2 \text { : general education school level; } 3 \text { : } \\
\text { secondary school level; } 4 \text { : A-level; } 5 \text { : university of } \\
\text { applied sciences } \$ \text { degree or university degree] }\end{array}$ & $\begin{array}{l}19 \% \text { general education school level; } 45 \% \\
\text { secondary school level; } 12 \% \text { A-level; } 24 \% \\
\text { university of applied sciences degree or } \\
\text { university degree }\end{array}$ \\
\hline Occupation & $\begin{array}{l}\text { Dummy variables to describe occupation status } \\
\text { [1: employed; } 1 \text { : self-employed; } 0: \text { unemployed, } 0 \text { : } \\
\text { in training/student, 0: retired; 0: housewife/-man] }\end{array}$ & $\begin{array}{l}47.2 \% \text { employed; } 5 \% \text { self-employed; } 9.6 \% \\
\text { unemployed; } 5.3 \% \text { in training/student; } \\
30.1 \% \text { retired; } 2.8 \% \text { housewife/-man }\end{array}$ \\
\hline Income & $\begin{array}{l}7 \text { categories from } \\
<500 € \text { to }>4000 € / \text { month/person }\end{array}$ & $\begin{array}{l}1,125 € / \text { month/person } \\
(760.5 € / \text { month/person })\end{array}$ \\
\hline Residence & $\begin{array}{l}\text { Dummy variable describing residence of } \\
\text { respondents [0: rural; } 1: \text { urban] }\end{array}$ & $\begin{array}{l}31.6 \% \text { urban resident } \\
68.4 \% \text { rural resident }\end{array}$ \\
\hline $\begin{array}{l}\text { NP user } \\
\text { status }\end{array}$ & $\begin{array}{l}\text { Dummy variable if respondent was at least once in } \\
\text { Hainich NP }[0: \text { no; } 1: \text { yes }]\end{array}$ & $86 \%$ visited Hainich NP at least once \\
\hline $\begin{array}{l}\text { Frequency of } \\
\text { NP visits }\end{array}$ & Frequency of visiting Hainich NP/year & $14.01(38.2)$ \\
\hline
\end{tabular}

\subsection{Importance of attributes for respondents}

According to Figure 4, $91.4 \%$ of respondents rated the attribute climate change mitigation by carbon sequestration as very important to rather important. $80.5 \%$ rated the attribute climate change adaptation by pest and storm resilience as very important or rather important. General ecosystem resilience adaptation received $68.5 \%$ of respondents for very important to rather 
important. $55.3 \%$ of respondents rated climate change adaptation towards invasive plants as very important to rather important.

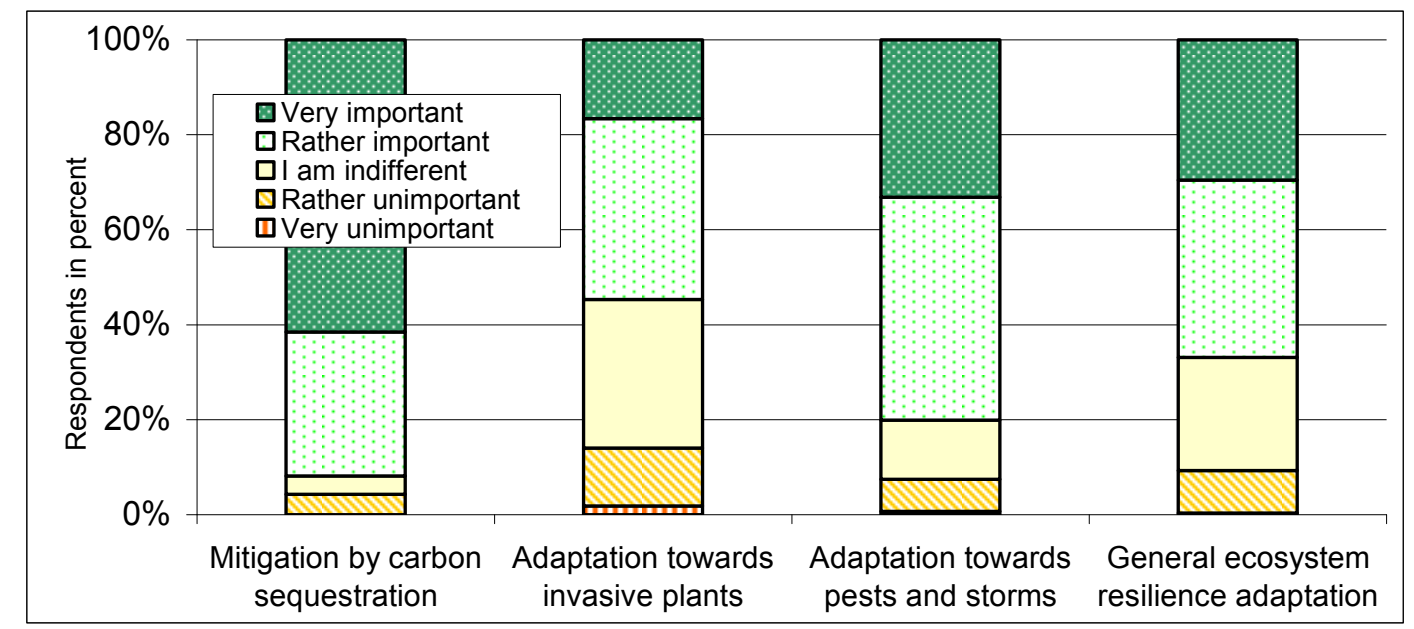

Figure 4. Importance of climate change mitigation and adaptation rated by respondents

\subsection{Base model results}

The model is overall most highly significant $\left(\mathrm{Pchi}^{2}<0.0001 ; \mathrm{DF}: 7\right)$. All attributes are significant determinants of choice; four attributes (including cost attribute) at $p<0.001$ and one attribute at $\mathrm{p}<0.05$ (Table 4). Before correction for protest responses, mWTP (marginal WTP) values for a one-level change in attributes ranges from $27.54 €$ to (-)9.59 $€$. Including protest responses (6.62\% of respondents) as ' 0 ' $€ \mathrm{mWTP}$, slightly lower mWTP values are obtained. In the following, corrected mWTP values are shown in parenthesis. While respondents appreciate afforestation, and increasing protection levels against pest and storms as well as they support general forest ecosystem resilience, more aggressive measures to reduce potential threats from invasive plants are disliked. Climate change adaptation to the risks by pests and storms has the highest mWTP: $27.54 €(25.71 €)$. For 'climate change mitigation', a mWTP of $21.43 €(20.01 €)$ per level is calculated, and of nearly $17 €(15.71 €)$ per level for general forest ecosystem resilience. For the moderate control of obviously 


\section{Chapter III}

dangerous plants such as $H$. mantegazzianum respondents are willing-to-pay $9.59 €(8.96 €)$ per person and year $(p<0.05)$ when compared to more aggressive removal schemes.

Taking mWTP values corrected for protest responses into account, a shadow price for C sequestration related to personal emissions can be calculated. Based on the mWTP value for one level change of $20.01 € \mathrm{a}^{-1}$ per $\sim 2.7 \mathrm{t} \mathrm{C}$ emissions $\mathrm{a}^{-1}$, a shadow price of $7.34 € \mathrm{t}^{-1} \mathrm{a}^{-1}$ can be calculated.

Table 4. Nested Logit estimation results of the Base Model

\begin{tabular}{|c|c|c|c|c|}
\hline Attribute & Coefficient & St. Error & $\begin{array}{c}\text { Uncorrected mWTP } \\
{[€ / \text { year/person }]}\end{array}$ & $\begin{array}{c}\text { Protest answer corrected } \\
\text { mWTP [€/year/person] }\end{array}$ \\
\hline \multicolumn{5}{|l|}{ Climate change mitigation } \\
\hline Afforestation $/ 100$ & $0.3537 * * *$ & 0.0466 & 21.43 & 20.01 \\
\hline \multicolumn{5}{|l|}{ Climate change adaptation } \\
\hline Invasive plants & $-0.1582 *$ & 0.0711 & -9.59 & -8.96 \\
\hline Pests and storms & $0.4545 * * *$ & 0.0476 & 27.54 & 25.71 \\
\hline $\begin{array}{l}\text { General ecosystem } \\
\text { resilience adaptation }\end{array}$ & $0.2777^{* * *}$ & 0.0462 & 16.83 & 15.71 \\
\hline Status Quo-ASC & $-2.2740 * * *$ & 0.5068 & -137.80 & -128.66 \\
\hline COST & $-0.0165 * * *$ & 0.0014 & - & - \\
\hline Log-likelihood & -2257.510 & & & \\
\hline Chi-squared & 1041.248 & & & \\
\hline Pseudo- $R^{2}$ & 0.0621 & & & \\
\hline Observations & 2256 & & & \\
\hline
\end{tabular}

\subsection{Model interactions: Influences of socio-demographic characteristics of respondents}

Age, gender and education are concurrently interacted with the afforestation attribute (climate change mitigation and adaptation) and the ASC; four interactions fall below a $P$-value of 5\%. The interaction between age and climate change mitigation points out $(\mathrm{p}<0.01$; Table 5$)$ that age (coded in years between 18 and 92) has a positive effect on preferences for the proposed climate change mitigation measures (if an improvement measure is chosen). Gender interacted with the climate change mitigation attribute indicates that women (women coded ' 0 '; men coded ' 1 ') have stronger preferences for the proposed climate change mitigation 


\section{Chapter III}

measures $(\mathrm{p}<0.001)$. The lower the education level the higher the probability for the current situation (Status Quo) being chosen $(\mathrm{p}<0.05)$. Age has a positive effect on the probability for the current situation (Status Quo) being chosen $(\mathrm{p}<0.001)$.

Table 5. Nested Logit estimation results of the improved model

\begin{tabular}{|c|c|c|}
\hline \multirow{2}{*}{ Variable } & \multicolumn{2}{|c|}{ Improved model } \\
\hline & Coefficient & P-value \\
\hline \multicolumn{3}{|l|}{ Climate change mitigation } \\
\hline Afforestation/100 & $0.3297 * * *$ & 0.0000 \\
\hline Afforestation*age & $0.1111 * *$ & 0.0088 \\
\hline Afforestation $*$ gender $($ male $=1)$ & $-0.1538 * * *$ & 0.0004 \\
\hline \multicolumn{3}{|l|}{ Climate change adaptation } \\
\hline Invasive plants & $-0.1586^{*}$ & 0.0000 \\
\hline Pests and storms & $0.4191 * * *$ & 0.0000 \\
\hline General ecosystem resilience adaptation & $0.2481 * * *$ & 0.0000 \\
\hline Status Quo-ASC & $-1.2635 * * *$ & 0.0000 \\
\hline Status Quo-ASC*age & $0.3008 * * *$ & 0.0000 \\
\hline Status Quo-ASC*education & $-0.1238^{*}$ & 0.0174 \\
\hline Cost attribute & $-0.0157 * * *$ & 0.0000 \\
\hline Log-likelihood & -2230.352 & \\
\hline Chi-squared & 1095.564 & \\
\hline Pseudo- $R^{2}$ & 0.07252 & \\
\hline Observations & 2256 & \\
\hline
\end{tabular}

\section{Discussion}

We conducted a choice experiment on one climate change mitigation and three climate change adaptation attributes focusing on forest ecosystem biodiversity. Extensive qualitative pre-studies (Rajmis \& Barkmann 2007) had shown that respondents are sufficiently aware of the topics covered by our choice experiment attributes. To ensure understanding, attribute level details and wording were designed to reflect respondent previous knowledge on climate change risks, and forest-based adaptation and mitigation measures. Furthermore, the CE was conducted as a face-to-face survey based on sampling procedures that achieved a good match of included individuals with population means at large (Figure 3). The low number of respondents which protested the CE $(n=20 ; 6.62 \%)$ gives further support to our positive 
interpretation of the validity of the instrument with regard to the critical issue of respondent familiarity with ecosystem service-type CE attributes (cf. Barkmann et al. 2008).

Supporting content validity, all attributes are significant determinants of choice, and display meaningful signs of the attribute utility coefficients (see Bateman et al. 2002:363). WTP for climate change mitigation and adaptation ranges between $-8.96 €$ and $25.72 €$ per year and person for a one level change (cf. Table 2). The strongest WTP of $25.72 €$ per year and person was identified for one level change of climate change adaptation towards pests and storms. An independent importance rating of the used attributes by respondents before actually making the choice shows that mWTP follows the importance rating for most attributes (compare Table 4 and Figure 4).

The ASC value regarding climate change measures in the Hainich forest area indicates that respondents have strong preferences for improving the Status Quo beyond what is depicted by the measures used in the actually displayed choice cards (negative ASC coefficient). Such a positive view of the proposed kind of measures is stronger with younger respondents (positive sign of interaction term ASC*age) and for better educated respondents (negative sign of interaction term $\mathrm{ASC}^{*}$ education). These results do not give any indication that choosing the Status Quo-Card was used as a simple 'opt out' at zero cost by respondents (compare to Barkmann et al. 2008). This would have constituted a so-called Status Quo 'bias' casting doubts on the results. The positive valuation of the proposed scenarios beyond explicitly depicted attributes shows also that respondents do associate additional, implicit benefits with the proposed measures. Certainly, we cannot categorically exclude that such implicit benefit assignments also influenced the valuation of the explicit mitigation and adoption attributes. Still, the material and statistical significance of the coefficient of the ASC terms supports the notion that most such benefits were actually captured by the ASC terms, 


\section{Chapter III}

and consequently do not interfere with the interpretation of the calculated mWTP for the climate change mitigation and adaptation attributes.

Viscusi \& Zeckhauser (2006) found a mean WTP of $0.32 €$ per gallon of gas to avoid global warming for a 30-year period. Similarly, Reiner et al. (2006) asked how much respondents would pay on top of their existing electric bill to 'solve global warming'. $90 \%$ of respondents were willing to pay a maximum of $32 €$ per month to 'solve global warming', which equals more than $400 € \mathrm{a}^{-1}$. Converting the Viscusi \& Zeckhauser (2006) result to a WTP per $\mathrm{t}$ carbon in fuel, this represents about $140 € \mathrm{t}^{-1}$ and about $170 €$ per average fuel consumption 2005 per person vehicle (calculation based on U.S. Department of Transportation 2008). This is much higher than the shadow price for the sequestration of one ton of carbon emitted in our results study of $7.34 € \mathrm{tC}^{-1}$ emitted per person $\mathrm{a}^{-1}$. These values cannot be directly compared, however, because the first value constitutes WTP for a fuel tax that stops global warming (and its potentially catastrophic negative effects) while our study proposes the much less ambitious effect of reducing one's own carbon net footprint. If we interpret the total documented WTP in our study for a one level improvement of climate change mitigation and adaptation measures including the Status Quo-ASC (see Table 4) WTP results in $190 €$ person $^{-1} \mathrm{a}^{-1}$. (as an equivalent to 'stopping climate change' or 'solving global warming', a similar value as implied by Viscusi \& Zeckhauser (2006) is found. In any case, our values are much lower than in the study by Rainer et al. (2006)).

Alavalapati et al. (2004) investigated benefits for three environmental attributes (carbon sequestration, water quality, wildlife habitats in silvopasture). Average WTP for moderate improvements in all three environmental attributes results in $\sim 94 € \mathrm{a}^{-1}$ per household for a five-year-program. For our four attributes, a one level 'improvement' results in a total WTP of $\sim 60 €$. Annual WTP for C-sequestration alone is estimated at between $\sim 39.5 €$ and $\sim \$ 42.7$ $€$ by Alavalapati et al. (2004), and between $\sim 20$ and $\sim 40 €$ in our study (one or two level 


\section{Chapter III}

improvement). Thus, WTP for C-sequestration alone appears lower in our study, but for all mitigation and adoption options it is higher, however again lower than Alavalapati et al. (2004) more inclusive bundle of environmental improvements. Additionally, some of the unexplained preferences for improvements over the Status Quo in our data (see above) may have been attributable to specific attributes if we had also used attributes with a wider scope, including, e.g., water quality and wildlife habitat. As actual values at each of these levels of comparison differ by less than a factor of two, we interpret our data as generally supporting the findings of Alavalapati et al. (2004).

In summary, several studies including this one document substantial citizen WTP for additional climate change mitigation and/or adaptation. The paucity of empirical data, and the diversity of approaches do not allow for a definite conclusion of the absolute level of citizen WTP for climate change mitigation and/or adaptation. Even much more elaborate attempts to compare studies than accomplished here, for example accounting for temporal differences in real purchasing power, and socio-economics differences between studies and samples will suffer from the incompatibility of the units by which $\mathrm{C}$-sequestration is quantified. While this may not be completely avoidable, we recommend that future studies include a best estimate of WTP per tC additionally sequestered per person $\mathrm{a}^{-1}$.

Most importantly, while comparing the few data sets available, it must be kept in mind that the specific benefits associated with mitigation or adaptation options to be valued, may influence value statements. We discussed several examples above. Furthermore, our study differs from existing work in its community focus. Respondents are faced with mitigation and adaptation options to be implemented in the Hainich forest region, a leisure and local tourism area frequently visited by $86 \%$ of respondents. This means that respondents directly benefit at 
least from the proposed adaptation options. If we had proposed to implement them farther away, lower stated preferences would be expected for other forests in Germany or abroad ${ }^{16}$.

Finally, the regional setting of our study has an interesting side effect in relation to nature conservation concerns. Because all mitigation and adaptation options presented rest on improvement of forest biodiversity, our results point out potential regional synergies between climate change and conservation policy. These synergies most likely do not exist for alternative climate change mitigation measures and the production of agricultural biofuels (Reijnders 2009, Pineiro et al. 2009).

Acknowledgement. We thank Deutsche Forschungsgemeinschaft (DFG Graduiertenkolleg 1086) for funding, our research assistants, the survey participants, Hainich area respondents for collaboration especially M. Großmann, M. Harcken for language editing, and three anonymous reviewers for helpful comments.

\section{References}

Adamowicz W, Louviere J, Swait J (1998a) Introduction to Attribute-Based Stated Choice Methods. Advanis Inc. for the National Oceanic and Atmospheric Administration, US Departement of Commerce

Adamowicz W, Boxall P, Williams M, Louviere J (1998b) Stated preference approaches to measuring passive use values. Am J Agric Econ 80: 64-75

Alavalapati JRR, Shrestha RK, Stainback GA, Matta, JR (2004) Agroforestry development: An environmental economic perspective. Agroforestry Systems 61:299-310 Australian Greenhouse Office (2004) Economic Issues Relevant to Costing Climate Change Impacts. Marsden Jacob Associates for the Australian Greenhouse Office.

\footnotetext{
16 We thank one of the anonymous reviewers for his comment on this issue.
} 
Accessed 21 July 08 www.greenhouse.gov.au/impacts/publications/costing.html Balser TC, Kinzig AP, Firestone MK (2002) Linking Soil Microbial Communities and Ecosystem Functioning. In: Kinzig AP, Pacala SW, Tilman D (eds) The Functional Consequences of Biodiversity, Princeton, Oxford, Princeton University Press, p 265293

Barkmann J, Glenk K, Keil A, Leemhuis C, Dietrich N, Gerold G, Marggraf R (2008) Confronting unfamiliarity with ecosystem functions: The case for an ecosystem service approach to environmental valuation with stated preference methods. Ecological Economics 65:48-62

Barkmann J, Glenk K, Handi H, Sundawati L, Witte JP, Marggraf R (2007) Assessing economic preferences for biological diversity and ecosystem services at the Central Sulawesi rainforest margin: a choice experiment approach. In: Tscharntke T, Leuschner C, Zeller M, Guhardja E, Bidin A (eds) Stability of Tropical Rainforest Margins. Springer, Berlin, Heidelberg, New York, p 181-208

Barkmann J, Marggraf R (2007) Weil wir Geld nicht essen können: zur ökologischen Katastrophenvorsorge durch biologische Vielfalt. In: Sandhoff K, Engel A, Ertl G, Linsenmair KE, Nüsslein-Volhard C, Sackmann E, Schwab W, Donner ME, Stetter J (eds) Vom Urknall zum Bewusstsein: Selbstorganisation der Materie. Georg Thieme, Stuttgart, p 175-192

Bateman IJ, Carson RT, Day B, Hanemann M, Hanley N, Hett T, Jones-Lee M, Loomes G, Mourato S, Özdemiroglu E, Pearce OBE DW, Sugden R, Swanson J (2002) Economic valuation with Stated Preference Techniques: A manual. Edward Elgar, Cheltenham, Northhampton

Berk RA, Fovell RG (1999) Public perceptions of climate change: A 'willingness to pay' assessment. Clim Chang 41:413-446 
Bernstein L, Bosch P, Canziani O, Chen Z and 36 others (2007) Climate Change 2007: Synthesis Report. An Assessment of the Intergovernmental Panel on Climate Change. Accessed 25 March 08 www.ipcc.ch/ipccreports/ar4-syr.htm

Bot A, Benites J (2005) The importance of soil organic matter. Key to drought: resistent soil and sustained food production. FAO, Rome

Buchmann N, Schulze ED (1999) Net $\mathrm{CO}_{2}$ and $\mathrm{H}_{2} \mathrm{O}$ fluxes of terrestrial ecosystems. Global Biogeochem Cycles 13:751-760

Bush GW (2001) Text of a letter from the President to Senators Hagel, Helms, Craig, and Roberts. Office of the Press Secretary. Accessed 20 Aug. 07 www.whitehouse.gov/news/releases/2001/03/20010314.html

Chrzan K, Orme B (2000) An Overview and Comparison of Design Strategies for ChoiceBased Conjoint Analysis. Sawtooth Software 2000-2002, Research paper series.

Cole DH (2007) The Stern Review and Its Critics: Implications for the Theory and Practice of Benefit-Cost Analysis. Accessed 21 July 08 http://ssrn.com/abstract=989085

Deckmyn G, Muys B, Garcia Quijano J, Ceulemans R (2004) Carbon sequestration following afforestation of agricultural soils: comparing oak/beech forest to shortrotation poplar coppice combining a process and a carbon accounting model. Global Change Biology 10:1482-1491

Dighton J (2003) Fungi in Ecosystem Processes. Dekker, New York

Edwards PJ, Abivardi C (1998) The value of biodiversity: where ecology and economy blend. Biol Conserv 83:239-246

EEA [European Environment Agency] (2005) Anfälligkeit für die Folgen der Klimaänderung und Anpassung an die Klimaänderung in Europa. Accessed 19 Dec. 06 www.eea.europa.eu (available in English) 
EIA [Energy Information Administration] (2002) Summary of the Kyoto Report: Assessment of Economic Impacts. Accessed 20 Aug. 07 ww.eia.doe.gov/oiaf/kyoto/economic.htm

Galvan GA, Burger-Meijer K, Kuiper ThW, Kik C, Scholten OE (2007) Breeding for improved responsiveness to arbuscular mycorrhizal fungi in onion. 3rd QLIF Congress, Hohenheim, Germany, March 20-23, 2007 Accessed 19 March 08 http://orgprints.org/view/projects/int_conf_qlif2007.html

Gitay H, Wilson JB, Lee WG (1996) Species redundancy: a redundant concept? J Ecol 84:121-124

Hensher D, Rose J, Greene W (2005) Applied choice analysis: a primer. Cambridge University Press, Cambridge

Jaspersen-Schib R, Theus L, Guirguis-Oeschger M, Gossweiler B, Meier-Abt PJ (1996) Acute poisonings with toxic giants in Switzerland between 1966 and 1994. Schweizerische Medizinische Wochenschrift 126:1085-1098

Jenkinson DS (1971) The accumulation of organic matter in soil left uncultivated. Rothamsted Experimental Station Report for 1970, p 113-137

Kernaghan G, Widden P, Bergeron Y, Légaré S, Paré D (2003) Biotic and abiotic factors affecting ectomycorrhizal diversity in boreal mixed-woods. Oikos 102:497-504

Knohl A, Schulze ED, Kolle O, Buchmann N (2003) Large carbon uptake by an unmanaged old deciduous forest in Central Germany. Agricultural and Forest Meteorology 118:151-167

Korpel Š (1995) Die Urwälder der Westkarpaten. Gustav Fischer, Stuttgart, Jena, New York Kowarik I (2003) Biologische Invasionen. Neophyten und Neozoen in Mitteleuropa. Ulmer, Stuttgart

Kromrey H (2006) Empirische Sozialforschung. Modelle und Methoden der standardisierten 
Datenerhebung und Auswertung. Lucius \& Lucius, Stuttgart

Kutsch W, Steinborn W, Herbst M, Baumann R, Barkmann J, Kappen L (2001)

Environmental Indication: A Field-test of an Ecosystem Approach to Quantify

Biological Self-organization. Ecosystems 4:49-66

Lancaster K (1966) A New Approach to Consumer Theory. Journal of Political Economy

$74: 132-157$

Levitus S, Antonov JI, Boyer TP, Stephens C (2000) Warming of the world ocean. Science $87: 2225-2229$

Logan JA, Regniere J, Powell JA (2003) Assessing the impacts of global warming on forest pest dynamics. Frontiers in ecology and the environment 1:130-137

McCann KS (2000) The diversity-stability debate. Nature 405:228-233

McFadden D (1973) Conditional Logit Analysis of Qualitative Choice Behavior. In : Zarembka P (ed) Frontiers in Econometrics. Academic Press, New York, p 105-142

Menkis A, Vasiliauskas R, Taylor AFS, Stenlid J, Finlay R (2007) Afforestation of abandoned farmland with conifer seedlings inoculated with three ectomycorrhizal fungi - impact on plant performance and ectomycorrhizal community. Mycorrhiza 17:337348

Meyer P, Tabaku V, von Lüpke B (2003) Die Struktur albanischer Rotbuchen-Urwälder: Ableitungen für eine naturnahe Buchenwirtschaft. Forstwissenschaftliches Centralblatt $122: 47-58$

Msangi S, Rosegrant, MW, You L (2006) Ex post assessment methods of climate forecast impacts. Clim Res 33:67-97

Mund M (2004) Carbon pools of European beech forests (Fagus sylvatica) under different silvicultural management. PhD dissertation, Georg-August-Universität Göttingen, Germany 
Chapter III

Myers N (1996) Environmental services of biodiversity. Proceedings of the National Academy of Sciences of the United States of America 93:2764-2769

Nordhaus W (2007) The Stern Review on the Economics of Climate Change. Accessed 21 July 08 http://nordhaus.econ.yale.edu/stern_050307.pdf

Parmesan C (2006) Ecological and evolutionary responses to recent climate change. Annual review of ecology evolution and systematics 37:637-669

Perrings C (1995) Biodiversity conservation as insurance. In: Swanson TM (ed) The economics and ecology of biodiversity decline: The forces driving global change. Cambridge University Press, Cambridge, New York, Melbourne p 69-77

Pineiro G, Jobbagy EG, Baker J, Murray BC, Jackson RB (2009) Set-asides can be better climate investment than corn ethanol. Ecological Applications 19:277-282

Pyšek P, Pyšek A (1995) Invasion by Heracleum mantegazzianum in different habitats in the Czech Republic. Journal of Vegetation Science 6:711-718

Rajmis S, Barkmann J (2007) Utilisation of Grounded Theory Methodology for the development of a choice experiment: Preliminary studies on the insurance value of biodiversity. In: Meyerhoff J, Lienhoop N, Elsasser P (eds) Stated Preference Methods for Environmental Valuation: Applications from Austria and Germany. Metropolis, Marburg p 175-202

Rajmis S, Barkmann J, Marggraf R (2008) Pythias Rache: Zum Tauschwert ökologischer Versicherung vor unbekannten Risiken. Submitted to GAIA - Ecological Perspectives for Science and Society

Reijnders L (2009) Acute View Transport biofuels: Can they help limiting climate change without an upward impact on food prices? Journal of consumer protection and food safety $4: 75-78$ 
Reiner DM, Curry TE, Defigueiredo MA, Herzog HJ, Ansolabehere SD, Itaoka K, Johnsson F, Odenberger M (2006) American Exceptionalism? Similarities and Differences in National Attitudes Toward Energy Policy and Global Warming. Environ Sci Technol 40:2093-2098

Rejmanek M (2000) Invasive plants: approaches and predictions. Austral Ecology 25:497506

Rizzo L, Brick JM, Park I (2004) A Minimally Intrusive Method for Sampling Persons in Random Digit Dial Surveys. Public Opinion Quarterly 68:267-274

Robertson GP, Vitousek PM (1981) Nitrification potentials in primary and secondary succession. Ecology 62:376-386

Ruddiman WF, Vavrus SJ, Kutzbach JE (2005) A test of the overdue-glaciation hypothesis, Quaternary Science Reviews 24:1-10

Statistisches Bundesamt (2008) Population of Germany, age and income distribution. Nonpublished data base obtained upon request (Excel data sheet).

Stern N (2006) The Economics of Climate Change. The Stern Review. Accessed 01 Aug 07 www.hm-treasury.gov.uk/Independent_Reviews /stern_review_economics_climate_change/sternreview_index.cfm.

Switzer GL, Shelton MG, Nelson LE (1979) Successional development of the forest floor and soil surface on upland sites of the east gulf coastal plain. Ecology 60: $1162-1171$

Talbot JM, Allison SD, Treseder KK (2008) Decomposers in disguise: mycorrhizal fungi as regulators of soil C dynamics in ecosystems under global change. Funct Ecol 22:955963

Thüringer Landesamt für Statistik (2008) Population of Thuringia, age and income distribution. Non-published data base obtained upon request (Excel data sheet) 
Tol RSJ (2007) The Social Cost of Carbon: Trends, Outliers and Catastrophes. Economics: The Open-Access, Open-Assessment E-Journal. Accessed 21 July 08 www.economics-ejournal.org/economics/discussionpapers/2007-44

Train K (1998) 'Recreation demand models with taste differences over people'. Land Economics 74:230-40

U.S. Department of Transportation (2008) Motor Vehicle Fuel Consumption and Travel in the U.S., 1960-2005. Accessed 15 August 08 www.infoplease.com/ipa/A0004727.html Viscusi WK, Zeckhauser RJ (2006) The Perception and valuation of risks of climate change: a rational and behavioral blend. Clim Chang 77:151-177

Watson RT, Noble IR, Bolin B, Ravindranath NH and 31 others (2000) Land Use, Land-Use Change, and Forestry. IPCC Special Report. Cambridge University Press, Cambridge

Williamson JA, Forbes JC (1982) Giant Hogweed Heracleum mantegazzianum: its spread and control with glyphosate in amenity areas. Proceedings of the British Crop Protection Conference - Weeds, Brighton, p 967-972

Yachi S, Loreau M (1999) Biodiversity and ecosystem productivity in a fluctuating environment: the insurance hypothesis. Proc Natl Acad Sci USA 96:1463-1468

Zebisch M, Grothmann T, Schröter D, Haße C, Fritsch U, Cramer W (2005) Klimawandel in Deutschland. Vulnerabilität und Anpassungsstrategien klimasensitiver Systeme. Potsdam-Institut für Klimafolgenforschung, Potsdam

Zelek CA, Shively G E (2003) Measuring the opportunity cost of carbon sequestration in tropical agriculture. Land Economics 79:282-298 


\section{Annex}

Background and calculations on WTP for additional sequestration of one ton self emitted carbon being sequestered by afforestation measures (see Table 2 for measures).

\section{Description of Status Quo calculation}

Hainich NP has around 7,600 ha; the whole Hainich forest area is about 16,000 ha. In the current situation (Status Quo) long term C accumulation of forest soils is estimated in a range between 2.4-450 $\mathrm{g} \mathrm{m}^{-2} \mathrm{a}^{-1}$ (see e.g. Robertson and Vitousek (1981), Switzer (1979)). For a beech stand in Hainich NP, high net carbon uptake values of up to $580 \mathrm{~g} \mathrm{~m}^{-2} \mathrm{a}^{-1}$ have been measured by Eddy covariance (Knohl et al. 2003). However, if we suggest smaller annual C sequestration rates (e.g. about $\left.9.2 \mathrm{~g} \mathrm{~m}^{-2} \mathrm{a}^{-1}\right)$, the whole Hainich area (16,000 ha) would display an annual $\mathrm{C}$ uptake of roughly $1,470 \mathrm{t}$. Converting $\mathrm{C}$ uptake into $\mathrm{CO}_{2}$ equivalents (conversion factor of $1 / 0.2727=3.6$ according due to the relation $\mathrm{C} / \mathrm{CO}_{2}$ and the molecular masses $\mathrm{C}: 12$ and $\left.\mathrm{O}_{2}: 32=12 / 44=0.2727\right)$, the carbon of about 5,400 $\mathrm{t} \mathrm{CO}_{2}$ could be sequestered. With an annual $\mathrm{CO}_{2}$ emission of about $10 \mathrm{t}^{\text {person }}{ }^{-1} \mathrm{a}^{-1}$ in Germany, this is equivalent to the $\mathrm{CO}_{2}$ emissions of about 540 citizens.

\section{Description of afforestation measures (Level 1 and Level 2 of the climate change mitigation attribute)}

Deckmyn et al. (2004) found by means of a carbon accounting model that an oak-beech forest reduces $\mathrm{CO}_{2}$ emissions between 6.2 and $7.1 \mathrm{t} \mathrm{CO}_{2} \mathrm{ha}^{-1} \mathrm{a}^{-1}$ (Deckmyn et al. 2004). Considering the $\mathrm{CO}_{2} / \mathrm{C}$ relation, this is a sequestration rate between $6.2 / 3.6=1.72 \mathrm{t} \mathrm{Cha}^{-1} \mathrm{a}^{-1}$ and $1.97 \mathrm{t} \mathrm{C}$ $\mathrm{ha}^{-1} \mathrm{a}^{-1}$. Sequestration rates by a young beech forest in southern France were estimated at max. $1.46 \mathrm{t} \mathrm{Cha}^{-1} \mathrm{a}^{-1}$ (Granier et al. 2000). 
Chapter III

Calculating with minimum sequestration rates from Deckmyn et al. (2004) of 6.2 t $\mathrm{CO}_{2}$ $\mathrm{ha}^{-1} \mathrm{a}^{-1}(900 / 6.2), 145$ ha would be needed to be afforested to sequestrate annually 245 additional t $\mathrm{C}$. Converted to German citizen $\mathrm{CO}_{2}$ emission equivalents, this equals about 90 average citizen $\mathrm{CO}_{2}$ emissions (difference between Status Quo and Level 1 and between Level 1 and Level 2). Taking a two level shift in account (from Status Quo to Level 2), about 290 ha would be needed to be afforested to compensate for 180 persons each emitting 10 tons $\mathrm{a}^{-1}$ 


\title{
Chapter IV
}

\section{Pythias Rache: Zum Tauschwert ökologischer Versicherung vor unbekannten Risiken}

\author{
Sandra Rajmis, Jan Barkmann und Rainer Marggraf
}

Pythia's revenge: On the exchange value of ecological insurance against unknown risks*

\begin{abstract}
Within the WBGU risk classification, Pythia- und Pandora risks pose particular challenges to environmental management (WBGU 1999:10). For these risks, it is principally unknown if, how, when, where, and how badly they strike. Potentially catastrophic disruptions in the provisioning of humans with critical ecosystem services may occur. It has been shown that at least partial "ecological insurance" against such risks is possible, mainly by biological diversity and, more generally, the capacity of ecological systems to selforganise. How much social and economic resources should be committed to ecological insurance? In this paper, we claim that this question can meaningfully be asked - and provide case study results on the corresponding economic value of ecological insurance measures hypothetically implemented in the area of Hainich National Park, Thuringa (Germany).
\end{abstract}

Keywords: ecosystem insurance services, biological diversity, Pandora and Pythia risks, choice experiment, willingness-to-pay, economic valuation, landscape management

\footnotetext{
*This manuscript has been submitted to GAIA - Ecological Perspectives for Science and Society
} 
Pythia- und Pandora-Risiken werfen für das Umweltmanagement besondere Herausforderungen auf (WBGU 1999:10). Denn für Risiken dieser Art ist es prinzipiell unbekannt, ob, wie, wann, wo und wie schwer sie zuschlagen. Im schlimmsten Fall ist mit katastrophenartigen Auswirkungen zu rechnen, die die Versorgung mit kritischen ÖkosystemDienstleistungen (z.B. Nahrung oder Regulationsleistung des Wasser- oder Kohlenstoffkreislaufs; vgl. UNEP 2003) unterbrechen.

Grundlegende Überlegungen zum Verhalten ökologischer Systeme lassen vermuten, dass zumindest eine teilweise "ökologische Versicherung” gegen Pythia und Pandora-Risiken möglich ist (ökologische Versicherungshypothese: Yachi und Loreau 1999, McCann 2000, Keil 2002). Entsprechende Vorsorgestrategien bauen auf dem Schutz der biologischen Vielfalt bzw. - allgemeiner - auf dem Schutz der Selbstorganisationsfähigkeit ökologischer Systems auf.

Die pragmatische Frage, in welchem Umfang die Gesellschaft wirtschaftliche Ressourcen für Vorsorgestrategien gegen Pythia- und Pandora-Risiken bereit stellen soll beispielsweise im Rahmen von Naturschutz- und Landschaftsplanung - , ist damit zwar gestellt, aber noch nicht beantwortet. In diesem Beitrag zeigen wir anhand einer Studie zur ökonomischen Bewertung ökologischer Versicherungsmaßnahmen im Gebiet des Nationalpark Hainich (Thüringen), dass diese Frage auch in ihrer quantitativen Form sinnvoll beantwortet werden kann (vgl. Perrings 1995).

\section{Das Problem unbekannter Risiken}

Eine der populärsten Institutionen zur Handlungsfolgenabschätzung des klassischen Altertums war das Orakel von Delphi (Schwab 1974:48). Dessen legendäre Kompetenz in wichtigen Bereichen der Zukunftsforschung bescherte dieser Einrichtung mit der Seherin Pythia einen Ruf, der auch nach fast 3000 Jahren kaum verblasst ist. In Pythias Weissagungen 
wurde zwar deutlich, dass möglicherweise eine große Gefahr drohen könnte, nicht jedoch, wie groß deren Eintrittswahrscheinlichkeit oder Schaden sei - oder wen sie treffen würde. So prophezeite Pythia dem König Krösus, dass ein Angriff auf Persien die Zerstörung eines großen Reichs bedeuten würde. Der angriffslustige Krösus verkannte, dass sein eigenes Reich gemeint war (WBGU 1999:10).

Führt die menschliche Gesellschaft kollektiv einen möglicherweise verhängnisvollen Krieg gegen die Natur? Für viele Umweltrisiken könnte es uns ergehen wie Krösus und seinem Reich: An abstrakten Warnungen fehlt es nicht, beispielsweise vor einem sich aufschaukelndem Treibhauseffekt, oder einer unerwartet synergistisch wirkenden Akkumulation persistenter organischer Schadstoffe (WGBU 1999:11). Welche Schadenspotenziale tatsächlich bestehen, mit welchen Eintrittswahrscheinlichkeiten Ereignisfolgen eintreten werden oder wer wie hart getroffen wird, ist selbst bei Berücksichtigung der besten verfügbaren Expertise ex ante jedoch nicht bekannt.

Diese Parallelen veranlassten den Wissenschaftlichen Beirat der Bundesregierung Globale Umweltveränderungen für derartige Risiken die Bezeichnung „Pythia-Risiken“ einzuführen (WBGU 1999:10; Figur 1). Bei Pythia-Risiken besteht hohe Ungewissheit in Bezug auf die Eintrittswahrscheinlichkeit sowie mögliche Schadwirkungen. Hier kann allein ein grundsätzliches Besorgnispotential angegeben werden. Ähnlich klassifiziert sind die Risiken vom Typ Pandora. Bei diesen Risiken wird zusätzlich vermutet, dass die hypothetisierten Schadwirkungen irreversibel, persistent und ubiquitär sind (WBGU 1999:11). Gerade in diesem Bereich sehr großen Unwissens fehlt selbst Fachleuten der Umweltplanung eine treffende Begrifflichkeit zur Diskussion sinnvoller Vorsorgestrategien (siehe Jaeger 2000 und EXKURS 1).

In diesem Beitrag erläutern wir zunächst unseren Ansatz für Vorsorgestrategien gegen unbekannte Umweltrisiken (Abschnitt 2). Anschließend führen wir im Abschnitt 3 eine Reihe 
von Versicherungs-Dienstleistungen ein, die das Waldökosystem unserer Fallstudie, der Hainich in Thüringen, erbringt. Diese Versicherungs-Dienstleistungen bzw. die ihnen zu Grunde liegenden Risiken bringen jeweils ein eigenes Profil an wahrgenommener Bedrohung und Vorhersagesicherheit mit. So unterscheiden sich die vergleichsweise gut bekannten Risiken von Stürmen im Wald stark von den schwer abschätzbaren Risiken des Klimawandels. Im Rahmen der empirischen Studie (Methoden: Abschnitt 4; Ergebnisse: Abschnitt 5) nutzen wird dieses Spektrum an unterschiedlichen Umweltrisiken, um die Versicherungs-Dienstleistungen vor unbekannten Risiken im Kontext ähnlicher, tendenziell besser bekannter Risiken zu untersuchen. Die in diesem Beitrag präsentierten Ergebnisse konzentrieren sich dabei auf eine Kernfrage: wie hoch ist die ökonomische Wertschätzung für die verschiedenen Vorsorge-Strategien in Abhängigkeit von dem von den Befragten eingeschätzten Besorgnispotential?

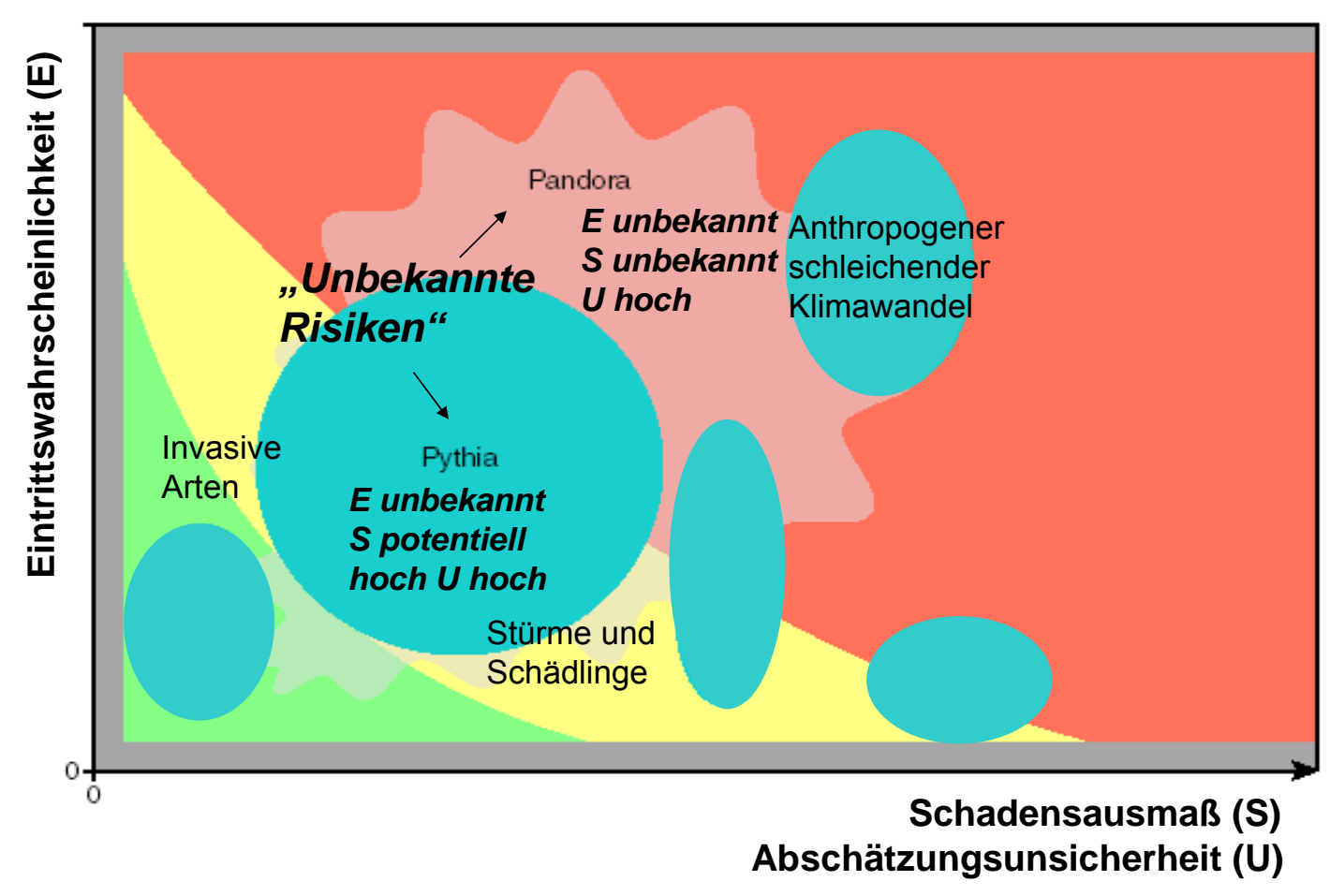

Figur 1. Klassifizierung von Risiken verändert nach WBGU (1999) 
EXKURS 1: „Lücke“ im Begriffsspektrum von Risiken

Verschiedene Risiko-Begrifflichkeiten entwickelte Jaeger (2000) anhand einer Expertenbefragung (Figur 2). Jaeger spricht von „Sicherheit“ eines Risikos, wenn die Folgen einer Handlung bekannt sind in dem Sinne, dass sie sicher abgeschätzt werden können. Der Biotopverlust durch Flächenversiegelung wird beispielsweise in den Wirkungsbereich von bekannten sicheren Folgen von Risiken eingestuft. Die Wirkung neuer Strassen auf den Wasserhaushalt wird als bekanntes kalkulierbares Risiko eingeschätzt. In der Mitte des Spektrums befinden sich ,plausible Risiken“, deren relevante potentielle Wirkungen zwar abschätzbar sind, die Wahrscheinlichkeit ihres Eintretens ist jedoch nicht kalkulierbar. Die Meeresspiegelerhöhung als Folge der Klimaveränderung wäre ein solches „plausibles Risiko“. Den höchsten Grad an Abschätzungsunsicherheit über Eintrittswahrscheinlichkeit und Schadensausmaß beherbergen Risiken, bei denen das Auftreten negativer Folgen völlig unabsehbar ist. An dieser Stelle klafft selbst bei den Experten eine „Lücke“ im Begriffsspektrum. Ein solches Risiko war in den 40er Jahren das Ozonloch, zu diesem Zeitpunkt nahezu unvorhersehbar als Folge der FCKW in der Atmosphäre. In diesem Bereich wären auch die Pythia und Pandora-Risiken anzusiedeln.

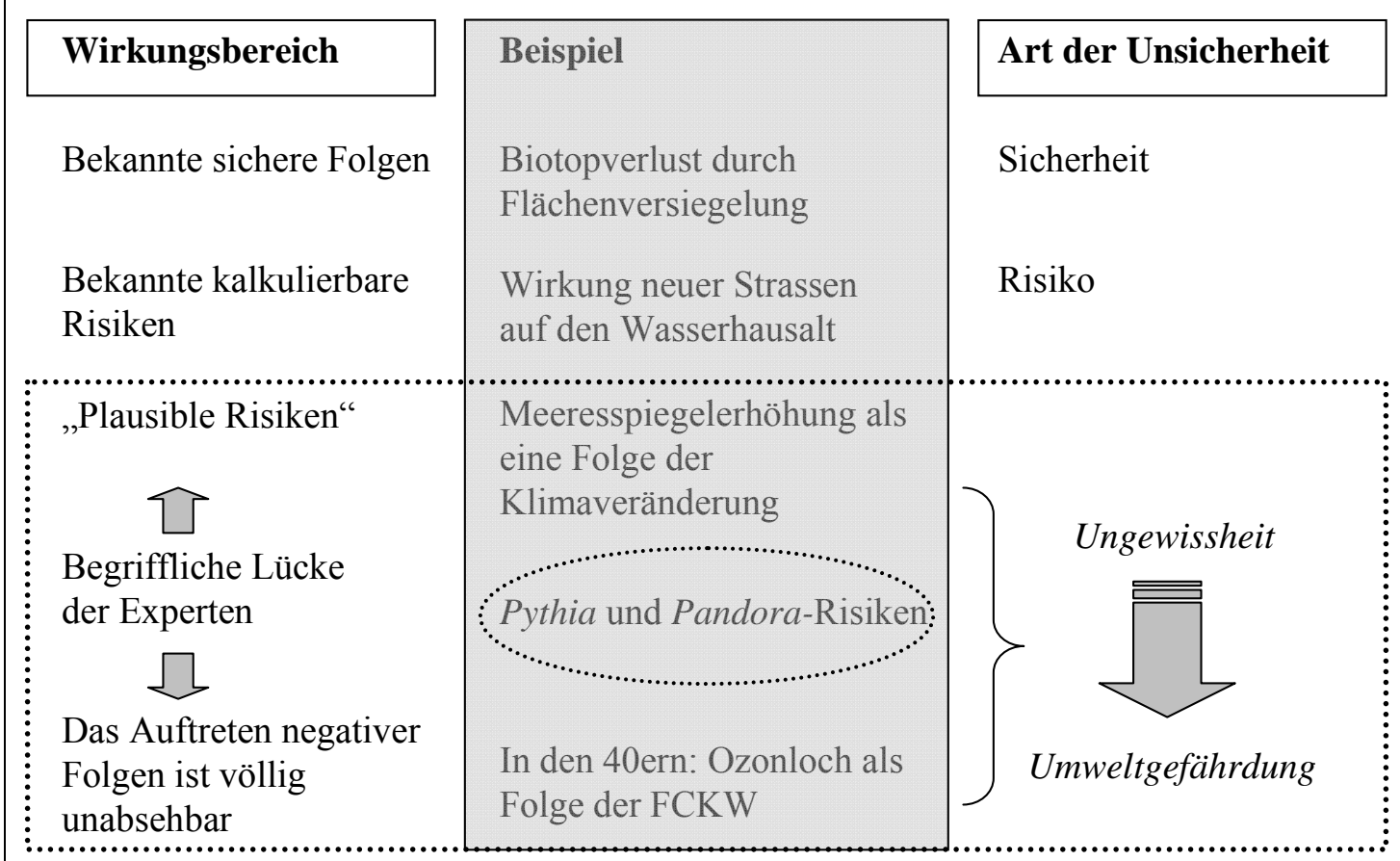

Figur 2. Risiko-Klassifizierung verändert nach Jaeger (2000) 


\section{Strategien zum Schutz vor unbekannten Katastrophenrisiken}

Diskussionen um eine treffende Begrifflichkeit oder Kategorisierung von unbekannten Katastrophenrisiken würden sich weitgehend erübrigen, wenn nicht zumindest in Umrissen geeignete Vorsorgemaßnahmen bekannt wären. In drei GAIA-Beiträgen wurden vor einiger Zeit von Seiten der Ökosystemforschung Schutz und Förderung der Selbstorganisationsfähigkeit ökologischer Systeme als mögliche Vorsorgestrategien eines „,nachhaltigen Landschaftsmanagements“ diskutiert (Barkmann et al. 2001a/b, Potschin und Haines-Young 2001). In diesen Beiträgen wurde argumentiert, dass fundamentale soziale, stochastische und epistemische Ungewissheiten eine hinreichend zutreffende Risikoabschätzung für gewisse abstrakte Gefährdungsklassen unmöglich machen.

Angesichts einer unüberwindlichen kognitiven Barriere kommen für diese Gefährdungsklassen nur Vorsorgestrategien in Frage, die nicht an dem einzelnen risikoseitigen Ereignis (,Agens“) ansetzen, sondern am Schutz des potenziell gefährdeten Umwelt-Systems (,Akzeptor“). Typische, aus den Ingenieurwissenschaften bekannte Strategien zur Erhöhung der „passiven“ Sicherheit einer Anlage angesichts unbekannter Gefährdungen setzen hier auf eine Erhöhung der strukturellen Diversität und Redundanz verschiedener System-Elemente. Dadurch werden Resilienz und Elastizität des GesamtSystems bei Störungen erhöht (WBGU 1999).

Diese Vorstellungen lassen sich weitgehend auf den Bereich ökologischer Systeme übertragen (Barkmann et al. 2001b; Kutsch et al. 2001). Die langfristige Resilienz und Elastizität der Ökosysteme beruht auf deren Fähigkeit zur ökologischen Selbstorganisation. Ein entscheidender Faktor für die Selbstorganisationsfähigkeit ist dabei die Verfügbarkeit biologischer Information(en), d.h. eine in der Regel hohe Biodiversität. Gemäß der ökologischen Versicherungs-Hypothese (Yachi und Loreau 1999, McCann 2000) sorgt eine hohe Artenvielfalt beispielsweise dafür, dass die zeitliche Varianz zentraler 
Ökosystemparameter der Tendenz nach sinkt. Sind in einem ökologischen System mehr Arten vorhanden, steigt beispielsweise die Wahrscheinlichkeit, dass eine Art die Funktion einer anderen übernehmen kann, wenn diese z.B. durch Trockenheit lokal ausstirbt (funktionale Redundanz; Tilman et al. 1996). Dies führt tendenziell dazu, dass weniger ausgeprägte Schwankungen von Ökosystemfunktionen wie etwa bei der pflanzlichen Produktion (Yachi und Loreau 1999, Tilman 1999), oder der Nährstoff-Rückhaltung (Loreau et al. 2002) auftreten.

Es kann aber auch zu Umweltveränderungen kommen, die den verstärkten Einsatz von Stoffwechselwegen oder anderen Ökosystemprozessen erfordern, die zuvor keine bedeutende Rolle gespielt haben. Ein Ökosystem mit vielen Arten besitzt mit höherer Wahrscheinlichkeit Organismen, die über die erforderlichen Funktionsmöglichkeiten verfügen (funktionale Diversität; McCann 2000).

Investitionen in die Erhaltung der biologischen Vielfalt gehören damit zu den wenigen Optionen, über Schutz und Förderung der Selbstorganisationsfähigkeit ökologischer Systeme Vorsorge vor Pythia und Pandora-Risiken zu betreiben. Aus gesellschaftlicher Sicht ist der Schutz vor diesen Risiken, wenn er durch die Strukturen und Prozesse ökologischer Systeme erfolgt, eine Ökosystem-Dienstleistung (UNEP 2003). Ökonomisch entspricht sie einem Optionswert, da ja unbekannt ist, ob und in welchem Umfang die jeweils geschützten Ökosystem-Prozesse oder Strukturen jeweils tatsächlich in der Zukunft Schäden verhindern können (Barkmann und Marggraf 2004).

Um zu vermeiden, dass die Befragten mit der Zustimmung zur hypothetischen Umsetzung von bestimmten Maßnahmen zum Schutz vor unbekannten Risiken an bereits bekannte Risken oder Gefahren denken und auch hierfür ihre Zahlungsbereitschaft ausdrücken, haben wir diese Risiken in den Kontext bekannterer Risiken gestellt. Somit stellen beide Arten von Risiken gleichzeitig Auswahloptionen für die Befragten innerhalb der 
angewandten Methode zur ökonomischen Bewertung dar. Damit wird vermieden, dass die Zahlungsbereitschaft für den Versicherungs-Schutz der Waldbiodiversität vor den dargestellten bekannten Risiken wie Klimaveränderungen oder Windwurf mit dem Versicherungsschutz vor unbekannten Risiken abgefangen wird.

\section{3. Ökosystemare Versicherungsdienstleistungen im Bereich des Hainich}

\section{Nationalparks}

Der Hainich ist als eines der größten zusammenhängenden Laubwaldgebiete in Deutschland (mit insgesamt 16.000 Hektar; der Nationalpark umfasst 7.600 ha) mit einer hohen Artenvielfalt ein beispielhaftes Gebiet für die Bereitstellung von ökosystemaren Versicherungsdienstleistungen.

Wie oben erwähnt (Kapitel 2) haben wir die Bewertung der unbekannten (Pythia und Pandora-) Risiken in den Kontext bekannterer Risiken gestellt. Somit untersuchen wir neben der Wertschätzung für Versicherungsdienstleistungen „des Hainich“ gegenüber den unbekannten Risiken die Wertschätzung gegenüber den mehr oder weniger „bekannten“ Risiken von Klimaveränderungen (Guckland et al. im Erscheinen, Freibauer und Schulze 2005, Mund 2004, Knohl et al. 2003, Robertson und Vitousek 1981, UNFCCC 2006), invasiven Arten (Kowarik 2003, Law et al. 2000, Moore et al. 2001, Abs 2004), Stürmen und Schädlingen (Schmidt 2005, Indermühle et al. 2005, Sobek et al. submitted). Auf diese „bekannten“ Risiken soll hier jedoch nicht weiter im Einzelnen eingegangen werden (siehe Tabelle 1).

Die möglichen Schutzwirkungen basieren jeweils auf ökologischen Phänomenen, die auf dem Schutz und der Förderung der (einheimischen) biologischen Vielfalt beruhen. Für die Auswahl und Formulierung der einzelnen Versicherungs-Dienstleistungen haben wir die Ergebnisse umfangreicher qualitativer Vorstudien angewendet (Rajmis und Barkmann 2007). 

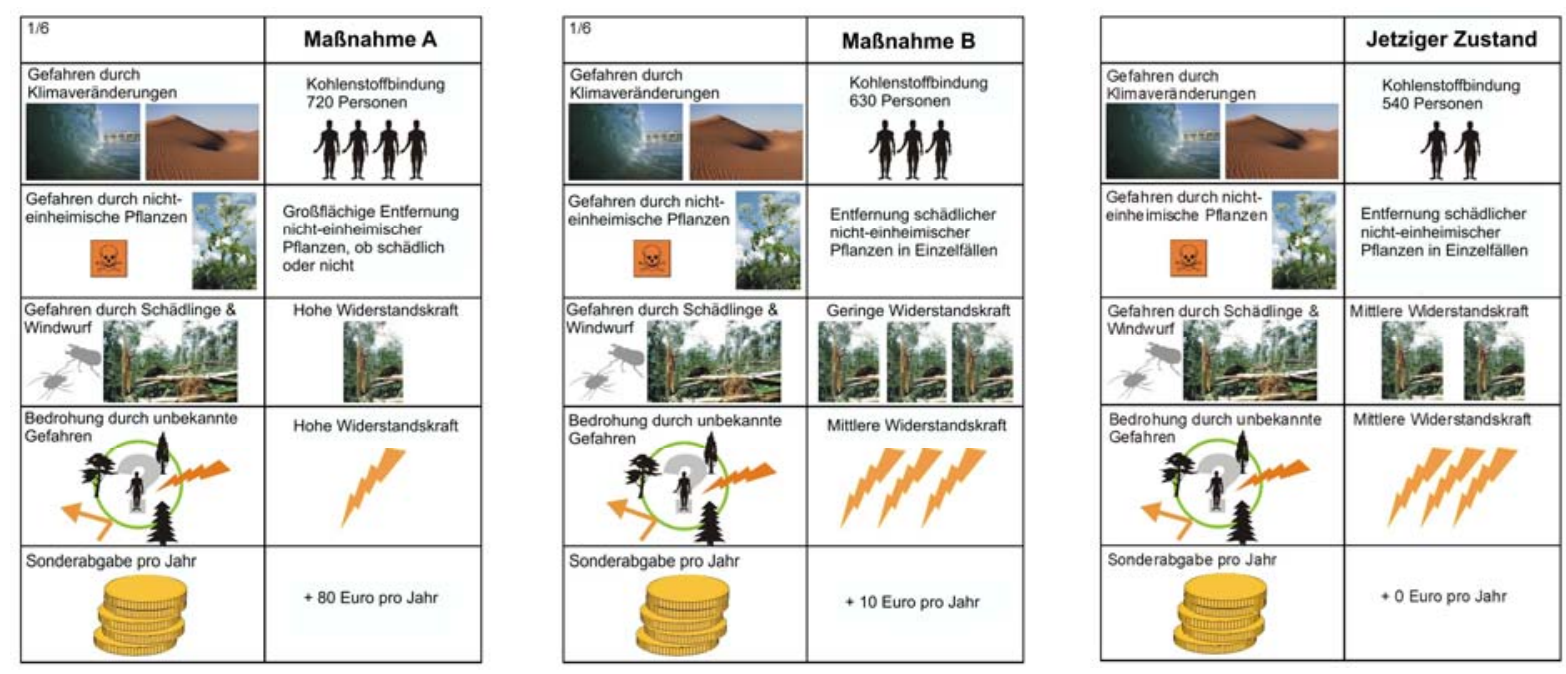

Figur 3. Exemplarische Karten aus dem Choice Experiment mit variierenden ökosystemaren Versicherungs-Dienstleistungen

Die Beschreibung der Versicherungsdienstleistungen endet jeweils mit Angaben zu mehreren „Maßnahmen“, mit denen die Versicherungsdienstleistungen im Untersuchungsgebiet gefördert werden können (siehe Abschnitt 4.1 und Figur 3).

\subsection{Mykorrhiza-Diversität des Waldes als Vorsorge vor unbekannten Risiken}

Für die Operationalisierung von Vorsorgestrategien gegen unbekannte Risiken standen wir vor mehreren methodischen Herausforderungen. Zunächst war über qualitative Vorstudien sicher zu stellen, dass die Befragten, die Grundkonzepte der Studie ausreichend verstehen. Dies war der Fall, wie in „EXKURS 2“ präsentierte exemplarische Aussagen belegen (für Details siehe Rajmis und Barkmann 2007). Jede Maßnahme zur Förderung der Selbstorganisationsfähigkeit von Waldökosystemen hat eventuell die Nebenfolge, dass sie von den Befragten als wichtiger angesehen wird, als die eigentlich intendierte Versicherungswirkung vor unbekannten Risiken. Eine Erhöhung der Artenzahl mit standortangepassten Bäumen oder Kräutern hätte so zum Beispiel auch als Schutz vor der 
vergleichsweise bekannten Gefährdung durch Stürme oder Schädlinge (siehe Tabelle 1) oder auch als ästhetisch ansprechender betrachtet werden können.

Tabelle 1. Die im Choice Experiment zu bewertenden ökosystemaren Versicherungs-Dienstleistungen

\begin{tabular}{|c|c|c|c|c|}
\hline Attribut & Maßnahme & \multicolumn{3}{|c|}{$\begin{array}{l}\text { Level oder Maßnahme } \\
\text { (Kodierung im Modell in Klammern) } \\
\end{array}$} \\
\hline $\begin{array}{l}\text { Versicherungs- } \\
\text { Dienstleistung gegen } \\
\text { Klimaveränderungen }\end{array}$ & $\begin{array}{l}\text { Zusätzliche } \mathrm{CO}_{2-} \\
\text { Fixierung durch } \\
\text { Baumanpflanzungen }\end{array}$ & $\begin{array}{l}\text { Kohlenstoff- } \\
\text { Bindung der } \\
\text { Emissionen von } \\
540 \text { Personen } \\
\text { (540) Status Quo }\end{array}$ & $\begin{array}{l}\text { Kohlenstoff- } \\
\text { Bindung der } \\
\text { Emissionen von } \\
630 \text { Personen } \\
(630)\end{array}$ & $\begin{array}{l}\text { Kohlenstoff- } \\
\text { Bindung der } \\
\text { Emissionen von } \\
720 \text { Personen } \\
(720)\end{array}$ \\
\hline $\begin{array}{l}\text { Versicherungs- } \\
\text { Dienstleistung gegen } \\
\text { invasive Pflanzen }\end{array}$ & $\begin{array}{l}\text { Entfernung nicht- } \\
\text { einheimischer } \\
\text { Pflanzen }\end{array}$ & $\begin{array}{l}\text { Entfernung } \\
\text { schädlicher } \\
\text { Pflanzen in } \\
\text { Einzelfällen } \\
\text { (1) Status Quo }\end{array}$ & \multicolumn{2}{|c|}{$\begin{array}{l}\text { Regelmäßige Entfernung, unabhängig } \\
\text { davon, ob sie schädlich sind oder nicht } \\
\text { (2) }\end{array}$} \\
\hline $\begin{array}{l}\text { Versicherungs- } \\
\text { Dienstleistung gegen } \\
\text { Stürme und } \\
\text { Schädlinge }\end{array}$ & $\begin{array}{l}\text { Anpflanzung von } \\
\text { standorttypischen } \\
\text { Baumarten }\end{array}$ & $\begin{array}{l}\text { Geringe } \\
\text { Widerstandskraft } \\
\text { (1) }\end{array}$ & $\begin{array}{l}\text { Mittlere } \\
\text { Widerstandskraft } \\
\text { (2) Status Quo }\end{array}$ & $\begin{array}{l}\text { Hohe } \\
\text { Widerstandskraft (3) }\end{array}$ \\
\hline $\begin{array}{l}\text { Versicherungs- } \\
\text { Dienstleistung gegen } \\
\text { unbekannte Gefahren } \\
\text { und Risiken }\end{array}$ & $\begin{array}{l}\text { Förder-Maßnahmen zu } \\
\text { Gunsten der } \\
\text { biologischen } \\
\text { Diversität von } \\
\text { Mykorrhiza-Pilzen }\end{array}$ & $\begin{array}{l}\text { Geringe } \\
\text { Widerstandskraft } \\
\text { (1) }\end{array}$ & $\begin{array}{l}\text { Mittlere } \\
\text { Widerstandskraft } \\
\text { (2) Status Quo }\end{array}$ & $\begin{array}{l}\text { Hohe } \\
\text { Widerstandskraft (3) }\end{array}$ \\
\hline $\begin{array}{l}\text { Kostenattribut } \\
\text { (zur Ermittlung der } \\
\text { Zahlungs- } \\
\text { bereitschaft) }\end{array}$ & $\begin{array}{l}\text { Einkommensänderung } \\
\text { pro Jahr }\end{array}$ & \multicolumn{3}{|c|}{$0 €($ Status Quo), $5 €, 10 €, 20 €, 35 €, 50 €, 60 €, 80 €$} \\
\hline
\end{tabular}

Eine weitgehende Fokussierung der Aufmerksamkeit der Befragten auf die Versicherungswirkung einer hohen biologischen Vielfalt vor unbekannten Schäden erhofften wir durch eine Thematisierung der Beziehung zwischen Mykorrhiza und Baum im Waldboden. Neben einer einführenden Erläuterung zur Bedeutung der Mykorrhiza im Hinblick auf Stressresistenz vor Trockenheit oder Schadstoffbelastungen (vgl. Balser et al. 2002:265, Schützendübel und Polle 2002) betonen wir im Fragebogen die Wichtigkeit der Mykorrhiza-Vielfalt gerade im Hinblick auf eine allgemeine Widerstandskraft des Waldökosystems gegenüber noch unbekannten Gefährdungen. 
Eine letzte methodische Herausforderung betrifft die Quantifizierung dieser Versicherungsdienstleistung. Schärfer noch als bei der Versicherung vor Schädlingen und Stürmen kann die Wirkung einer zahlenmäßig diverseren Gemeinschaft an Mykorrhiza-Pilzen auf die Vorsorgeleistung nicht genau quantifiziert werden. Wir haben wir uns daher auch hier auf die Bewertung von drei Vorsorgestufen (gering, mittel, hoch) beschränkt (siehe Tab. 1). Die „hohe Widerstandkraft“ stellt dabei eine Verbesserung gegenüber dem Status Quo dar, die „niedrige Widerstandskraft“ eine Verschlechterung.

EXKURS 2: Exemplarische Aussagen aus der qualitativen Vorstudie

\begin{tabular}{|c|c|c|c|c|}
\hline $\begin{array}{c}\text { Was die Befragten unter dem ökologischen } \\
\text { Versicherungsschutz verstehen }\end{array}$ & $\mathbf{m} / \mathbf{w}$ & Alter & Beruf & Int. \\
\hline „Das bedeutet mehr Absicherung unterschiedlicher Art.“ & $\mathrm{m}$ & 64 & Rentner & 1 \\
\hline $\begin{array}{l}\text { „Wenn eine Vorrichtung ausfällt, muss ich eine im Karton } \\
\text { haben.“"[...] „Also es ist schon sinnvoller, dass man für solche } \\
\text { Sachen im Prinzip was in petto hat, gewappnet ist.“ }\end{array}$ & $\mathrm{m}$ & 67 & Rentner & 2 \\
\hline $\begin{array}{l}\text { "Gemüse aus biologischem Anbau ist auch ein Art } \\
\text { Versicherung in diesem Sinne, sie schützt unseren Boden“ }\end{array}$ & $\mathrm{m}$ & 67 & Rentner & 2 \\
\hline „Das bedeutet, mehrgleisig zu fahren.“ & $\mathrm{m}$ & 59 & Lehrer & 3 \\
\hline $\begin{array}{c}\text { „Das bedeutet, je nach Situation unterschiedliche Mittel } \\
\text { einsetzen.“ }\end{array}$ & $\mathrm{m}$ & 30 & $\begin{array}{l}\text { wissenschaftlicher } \\
\text { Mitarbeiter }\end{array}$ & 7 \\
\hline $\begin{array}{c}\text { Es kann ja was auftreten, mit dem wir gar nicht rechnen. Was } \\
\text { wir vielleicht vorher nicht kannten und wenn da eine } \\
\text { Möglichkeit nicht funktioniert, hätten wir da noch die } \\
\text { Chance, dass eine andere funktioniert.“ }\end{array}$ & $\mathrm{W}$ & 28 & $\begin{array}{l}\text { Physio- } \\
\text { Therapeutin }\end{array}$ & 8 \\
\hline $\begin{array}{c}\text { "Auf alle Fälle mache ich das Risiko entsprechend kleiner. } \\
\text { [...] Im Gefahrenfall überlebt immer irgendein Teil" }\end{array}$ & $\mathrm{m}$ & 59 & Rentner & 12 \\
\hline
\end{tabular}

\section{4. Ökonomische Quantifizierung von ökosystemaren Dienstleistungen?}

Im Bereich der umweltökonomischen Forschung - die sich in den letzten 20 Jahren etabliert hat (Perrings 1995, Baumgärtner 2007) - wurde bisher noch kein Versuch unternommen, die ökosystemaren Versicherungs-Dienstleistungen der Waldbiodiversität oder generell der Artenvielfalt ökonomisch zu quantifizieren. Dies stellt aus unserer Sicht ein grosses Manko 
dar, da sich in den letzten 10 Jahren im Bereich der Biodiversitätsforschung einige grundsätzliche Annahmen zur ökosystemaren Versicherung (auf funktioneller Ebene) etabliert haben (Loreau et al. 2002) und daher in Zukunft an Bedeutung gewinnen. Neben der rein ökologischen Bedeutung sollte aber gerade die ökonomische und damit gesellschaftliche Wertschätzung einen Stellenwert erhalten, da wir nicht zuletzt auf der Bereitstellung dieser ökosystemaren Dienstleitungen angewiesen sind und diese dementsprechend in Schutzprogrammen auch für zukünftige Generationen gesichert werden sollten. Um kostennutzen-relevante Argumente für eine Etablierung dieser Sicherung zu schaffen, ist eine ökonomische Quantifizierung unumgänglich. Im Folgenden zeigen wir einen Weg, die ökosystemaren Versicherungs-Dienstleistungen der Waldbiodiversität zu quantifizieren und in eine gesellschaftliche Wertschätzung zu transferieren.

\subsection{Die Methode: Das Choice Experiment}

Basierend auf Erkenntnissen zur ökologischen Versicherungshypothese (Yachi und Loreau 1999, McCann 2000) und Ergebnissen einer qualitative Vorstudie (Rajmis und Barkmann 2007) wurde das Choice Experiment durchgeführt (Pre-Test, $n=57$; Pilotstudie, $n=106$; Hauptstudie, $\mathrm{n}=302)$. Von 302 erfolgreich kontaktierten Haushalten beantworteten 282 Befragte den Fragebogen vollständig. 20 Befragte (6,6\%) brachen die Beantwortung ab („Protestantworten“; Adamowicz et al. 1998). Entsprechend wurden diese „Protestantworten“ von der Gesamtzahlungsbereitschaft abgezogen.

Bei unserem Choice Experiment werden den Befragten drei Kärtchen vorgelegt, zwischen denen sie eine Auswahl treffen sollen. Eines der Kärtchen beschreibt den gegenwärtigen Umweltzustand (Status Quo), während die zwei anderen Kärtchen Veränderungen gegenüber dem Status Quo umreißen. Jede der angesprochenen Eigenschaften der verschiedenen Umweltsituationen wird als „Attribut“ bezeichnet. Dabei handelt es sich in 
unserer Studie um die vier verschiedenen oben beschriebenen VersicherungsDienstleistungen. Jedes Attribut ist über seine Ausprägungen (Levels) quantifiziert.

Eines der Attribute - das Kosten-Attribut - gibt eine zusätzliche Steuerzahlung zwischen $0 €$ und $80 €$ pro Jahr und Person an, die zusammen mit den dargestellten Veränderungen eintritt. Über die Beobachtung wiederholter Auswahlentscheidungen zwischen den Kärtchen kann über Maximum Likelihood-Analysen die relative Bedeutung der Attribute auf die Auswahlentscheidung ökonometrisch bestimmt werden (Adamowicz et al. 1998). Da das Kosten-Attribut in Geldeinheiten quantifiziert ist, lassen sich über den Vergleich des Einflusses der Versicherungsattribute mit dem Einfluss des Kosten-Attributes Zahlungsbereitschaften bzw. „Schattenpreise“ für die Versicherungsattribute errechnen ${ }^{1}$. Drei beispielhafte Auswahlkärtchen sind in Figur 3 abgebildet.

\subsection{Erfassung der Risikowahrnehmung von Befragten}

Ein weiterer Teil des Fragebogens bestand aus selbst entworfenen Items zur Frage der Abschätzungssicherheit bzw. -unsicherheit der Befragten bezüglich der verschiedenen Risiken. Um die Frage zu beantworten, ob die Abschätzungssicherheit bzw. -unsicherheit bezüglich der benannten Risiken einen Einfluss auf die Zahlungsbereitschaft hat, haben wir ein Item-Spektrum zur Erfassung der Risikowahrnehmung von Befragten zu verschieden definierten Formen von Risiken erstellt (siehe Figur 4).

A priori nahmen wir an, dass das Item-Spektrum einen Bereich zwischen „bekannten“ Auslösern bzw. Folgen von Risiken bis hin zu „völlig unabsehbaren“ Auslösern bzw. Folgen Risiken abdeckt. Wir fragten jeweils: „Für wie wahrscheinlich oder ungewiss halten Sie die folgenden Bedrohungen?“ Auf einer Likert-Skala wurden fünf Antwortmöglichkeiten von

\footnotetext{
${ }^{1}$ Weitere technische Details zur Anwendung der Choice Experiment Methodik sind zu finden in Rajmis et al. (accepted).
} 
„sehr wahrscheinlich“ (Kodierung 5) bis „sehr ungewiss“ (Kodierung 1) vorgegeben (Items in Figur 4). Das Item-Spektrum reicht von dem Risiko der „Klimaveränderung durch die Abholzung von Wäldern“ bis zur „Bedrohung durch neue unbekannte (völlig unabsehbare) Naturgefahren“.

„Bekannte“ Auslöser
bzw. Folgen von
Risiken

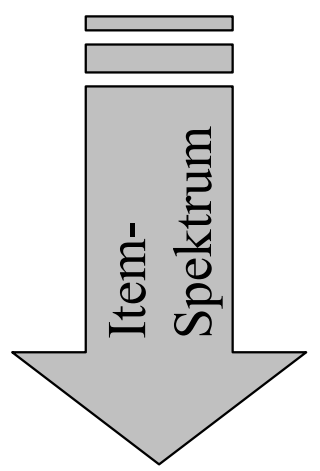

Auslöser bzw. Folgen von Risiken sind „völlig unabsehbar“

\section{Darstellung der Items im Fragebogen}

Klimaveränderung durch die Abholzung von Wäldern

Mehr Schädlinge \& Windwurf in Wäldern durch standortuntypische Baumarten

Dass die Widerstandskraft der Wälder verloren geht und damit alle positiven Wirkungen

Neue unbekannte Naturgefahren als Folge der Zerstörung von Wäldern

Neue unbekannte Naturgefahren, die durch fehlende Artenvielfalt im Wald Schaden verursachen

Die Bedrohung durch neue unbekannte Naturgefahren

Die Folgen von neuen Naturgefahren werden sich auch auf mein Leben auswirken

Figur 4. Item-Spektrum zur Erfassung der Risikowahrnehmung von Befragten

Im Ergebnisteil berechnen wir für die sich aus einer mit allen im Fragebogen angebotenen Items durchgeführten Faktorenanalyse ergebende Dimension, wie sich die individuelle Abschätzungs-(un-)sicherheit auf die Zahlungsbereitschaft für die VersicherungsDienstleistung vor unbekannten Risiken auswirkt. Technisch erfolgt die Berechnung über die Einführung von Interaktionstermen zwischen der „Versicherungs-Dienstleistung gegen unbekannte Risiken“ des Choice Experiments und den Variablen der Risikowahrnehmung. 
Auf einen Einfluss kann geschlossen werden, wenn der berechnete Nutzenkoeffizient des Interaktionsterms statistisch signifikant wird.

\section{Ergebnisse}

\section{1 Ökonomische Risikobewertung}

Das Grundmodell (a) in Tabelle 2 zeigt, dass die vier Attribute, die Versicherungsdienstleistungen gegenüber den unterschiedlichen Risiken darstellen, einen signifikanten Einfluss auf die Auswahlentscheidung haben. Die ökonomische Wertschätzung der Befragten ist unterschiedlich für die verschiedenen Vorsorgestrategien. Für die „Versicherungs-Dienstleistung gegen unbekannte Risiken“ beträgt sie im Grundmodell 15,72 $€$ pro Person und Jahr, für die Versicherungs-Dienstleistungen gegen Klimaveränderungen 20,01 € pro Person und Jahr und für die Versicherungs-Dienstleistung gegen Schädlinge und Windwurf 25,72 € pro Person und Jahr. Was die invasiven Pflanzen betrifft, haben die Befragten eine Präferenz und Zahlungsbereitschaft für die Variante mit der Entfernung von offensichtlich gefährlichen invasiven Pflanzen wie dem Riesenbärenklau (Heracleum mantegazzianum) von (-) 8,96€ pro Person und Jahr, im Vergleich mit der Variante, die eine Entfernung aller nicht-einheimischer Pflanzen beinhaltet.

Interagiert man die durch eine Faktorenanalyse ermittelte Dimension (Cronbach's Alpha 0.743) zur Abschätzungs-(un-)sicherheit mit der Versicherungs-Dienstleistung gegen unbekannte Risiken, so lässt sich ein Einfluss dieser Dimension auf die Auswahl der Versicherungs-Dienstleistung feststellen (Modell (b); Tabelle 2) und entsprechend die Zahlungsbereitschaft ermitteln (siehe 5.2). Der Likelihood-Ratio Test zeigt, dass das Dimensionsmodell (b) eine Verbesserung gegenüber dem Grundmodell (ohne Risikoeinschätzung) darstellt. 
Tabelle 2. (a) Grundmodell und (b) Dimensions-Modell

\begin{tabular}{|c|c|c|}
\hline Variable & (a) Grundmodell & (b) Dimensions-Modell \\
\hline Klimaveränderungen/100 & $0,312595 * * *$ & $0,315208 * * *$ \\
\hline Invasive Pflanzen & $-0,157833^{*}$ & $-0,161353^{*}$ \\
\hline Stürme \& Schädlinge & $0,397758 * * *$ & $0,394356^{* * *}$ \\
\hline Unbekannte Gefahren \& Risiken & $0,223785 * * *$ & $0,220620 * * *$ \\
\hline Kosten (Ermittlung der ZB) & $-0,015089 * * *$ & $-0,015134 * * *$ \\
\hline $\begin{array}{l}\text { Interaktion: Attribut "Unbekannte Risiken"* } \\
\text { "Risikowahrnehmungs-Dimension" }\end{array}$ & - & $0,137821 * * *$ \\
\hline Log Likelihood & $-2261,974$ & $-2256,181$ \\
\hline Likelihood-Ratio Test & - & $* * *$ \\
\hline $\mathrm{P}\left(\mathrm{Chi}^{2}\right) ; \mathrm{DF}$ & $<0,0001 ; 7$ & $<0,0001 ; 8$ \\
\hline Adj. Pseudo- $R^{2}$ (Const. only) & 0,06021 & 0,06241 \\
\hline \multicolumn{3}{|c|}{$\begin{array}{l}* * \text { signifikant bei } \mathrm{p}<0.001 ;{ }^{* *} \text { signifikant bei } \mathrm{p}<0.01 ;{ }^{*} \text { signifikant bei } \mathrm{p}<0.05 \\
\text { Pseudo- } R^{2} \text { (Adjusted } R^{2} \text {, constants only Modell-Werte) von 0,06-0,07 entsprechen } R^{2}-\text { Werten zwischen } 0,19- \\
0,22 \text { von linearen Modellen (Hensher et al.2005:338); }{ }^{\&} \text { Likelihood-Ratio Test, um zu testen ob das Modell mit } \\
\text { dem Interaktions-Term (b) eine Verbesserung gegenüber dem Grundmodell (a) darstellt; } \mathrm{n}=282 ; \text { die Kodierung } \\
\text { der Attribute ist in Tabelle } 1 \text { erläutert }\end{array}$} \\
\hline
\end{tabular}

\subsection{Zahlungsbereitschaft für ein funktionierendes Waldökosystem als Vorsorge vor}

\section{unbekannten Risiken}

Figur 5 zeigt die Abhängigkeit der Zahlungsbereitschaft von der Risikoeinschätzung gemäß Dimensions-Modell (b). Hierin sind die Informationen zur Risikowahrnehmung der Befragten zu den einzelnen Items (Figur 4) enthalten. Bei der Durchschnitts-Einschätzung der Befragten von 3,7 (Mittelwert der Dimension) liegt die marginale Zahlungsbereitschaft für eine Verbesserung des Schutzes vor unbekannten Risiken bei $14,40 €$ pro Person und Jahr. Die Zahlungsbereitschaft steigt auf $18,67 €$ pro Person und Jahr für eine nur leicht auf den SkalenWert von 4 (,eher wahrscheinlich“) erhöhte Risikoeinschätzung. Nimmt man dagegen eine Risikoeinschätzung von nur „eher ungewiss“ (Skalen- bzw. Dimensions-Wert von 2) an, sinkt die Zahlungsbereitschaft bei $-9,98 €$ pro Person und Jahr. Insgesamt ist nach diesem Modell formal für 20 von 282 Befragten die Zahlungsbereitschaft negativ für den Bereich von „sehr“ bzw. „eher ungewisser“ Risikoeinschätzung. Die negative Zahlungsbereitschaft drückt aus, dass die Befragten für diesen Bereich keinen Nutzen empfinden. Insgesamt lässt sich 


\section{Chapter IV}

feststellen: für je sicherer das Eintreffen der vorgestellten Risiken gehalten wird, desto höher die Zahlungsbereitschaft.

Für wie wahrscheinlich oder ungewiss halten Sie die folgenden Bedrohungen?

(siehe Item-Darstellung in Figur 4)

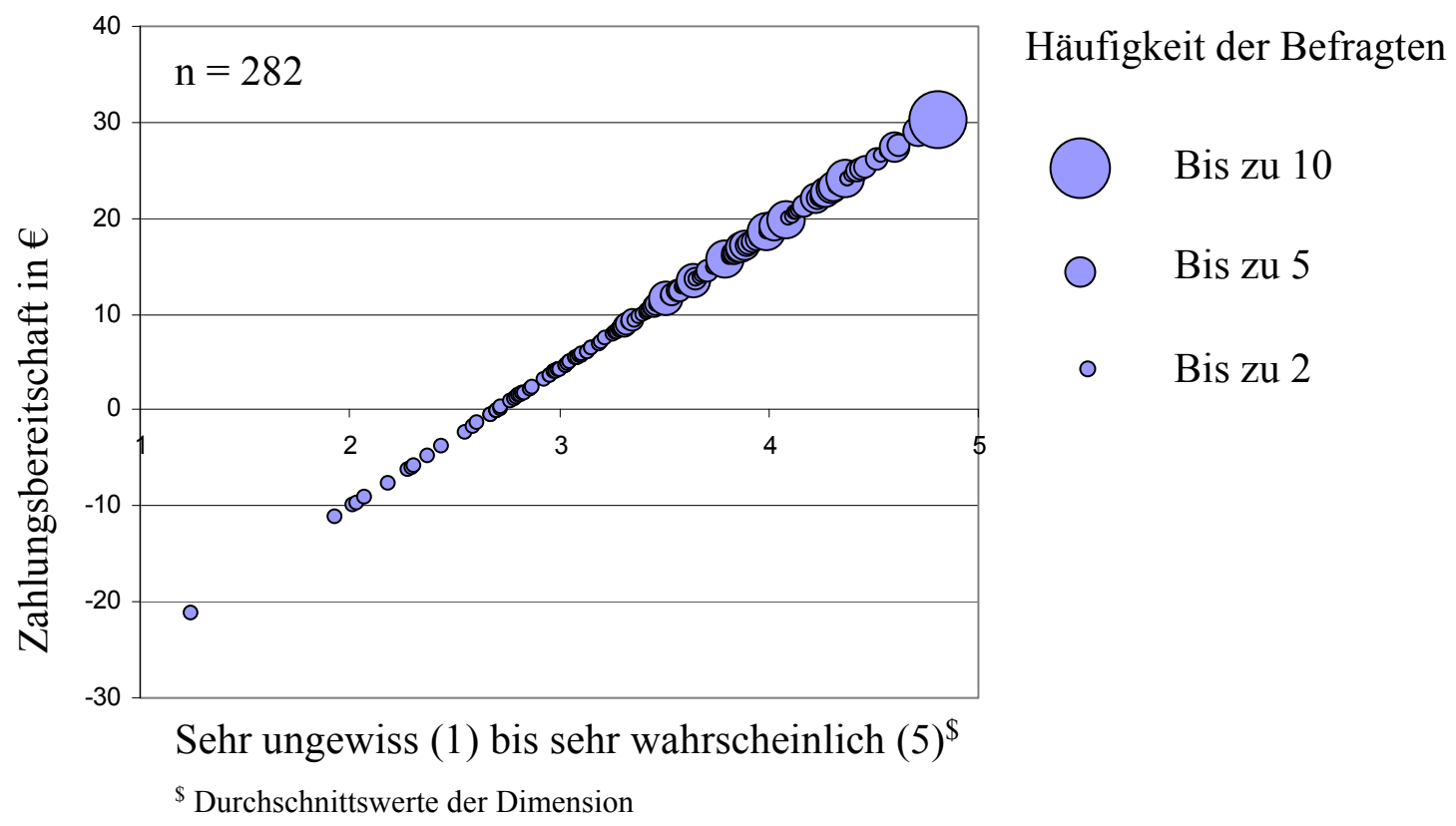

Figur 5. Zahlungsbereitschaften in Abhängigkeit zur Risikoeinschätzung

\section{Diskussion}

Eingebettet in drei weitere Risiken, für deren pro-aktive Bewältigung „biodiverse“ Waldökosysteme eine Rolle spielen (Klimawandel, invasive Pflanzen, Sturm- und Schädlingsrisiken), schätzen wir die Zahlungsbereitschaft für ökosystemare VersicherungsDienstleistungen gegen unbekannte Risiken ab. Der Wert der biologischen Vielfalt für ökosystemare Versicherungs-Dienstleistungen wird in der Umweltökonomik (z.B. Perrings 1995, Baumgärtner 2007) und in der dem ökonomischen „Mainstream“ gegenüber kritisch eingestellten Ökologischen Ökonomik seit längerem anerkannt (Folke et al. 1996: „natural insurance capital'). Innerhalb eines wohlfahrtsökonomischen Rahmens führt unsere Studie 
die Forschung zur ökonomischen Bewertung von Ökosystem-Dienstleistungen angesichts einer ungewissen Zukunft konsequent weiter.

Die Neigung, die aufgeführten Risiken insgesamt als eher wahrscheinlich einzuschätzen, erwies sich insbesondere für die unbekannten Risiken als statistisch signifikanter Prädiktor der Wertschätzung für die korrespondierende ökosystemare Versicherungs-Dienstleistung. Der ermittelte Wert für Cronbach's Alpha deutet darauf hin, dass mit den vorgeschlagenen Items das Gefährdungspotential der Risiken sinnvoll gemessen werden kann.

Der Einfluss der einzelnen Attribute ist dabei durchaus unterschiedlich. In marginale Zahlungsbereitschaften umgerechnet ergibt sich etwa für einen verstärkten Schutz vor Klimaveränderungen $20 € /$ Person/Jahr, für einen verbesserten Schutz vor unbekannten Risiken 14-20 €/Person/Jahr (je nach Risikoeinschätzung der Befragten). Die Tatsache, dass solche - zu erwartenden - Präferenz-Unterschiede systematisch aufgetreten sind, kann als Qualitätsmerkmal unserer Studie betrachtet werden. Das Fehlen klarer Unterschiede hätte den Schluss nahe gelegt, dass die Auswahlentscheidungen der Befragten nur sehr unspezifisch die Unterschiede zwischen den Attributen widerspiegeln. Eine Verbesserung aller Attribute (außer invasive Pflanzen) um eine Stufe wird von den BewohnerInnen des Hainich mit ca. $5 €$ pro Person und Monat bewertet. Aus diesem Betrag kann im Vergleich mit anderen Studien (z.B. Liebe 2007) zumindest nicht auf eine Überschätzung der von uns abgeschätzten Zahlungsbereitschaft geschlossen werden.

\section{Ausblick}

Gehen wir konservativ davon aus, dass pro Haushalt nicht jeder Erwachsene bereit ist im Durchschnitt $15 €$ pro Jahr für einen zusätzlichen Schutz vor unbekannten Pythia und Pandora-Risken auszugeben, sondern nur 1 Person pro Haushalt. Berücksichtigt man nun alle 
Haushalte der recht kleinen Untersuchungsregion zwischen Eisenach und Bad Langensalza, so ergibt dies bereits Summe von insgesamt rund $600,000 €$, die zusätzlich pro Jahr zur Verfügung stehen. Eine Verbesserung aller Versicherungs-Dienstleistungen um je eine Stufe (siehe Tabelle 1) würde bereits 2,4 Millionen Euro im Projektgebiet erbringen. Im Jahr 2005 wurden in ganz Thüringen ca. 2,93 Millionen Euro für den Waldnaturschutz ausgegeben (Thüringer Ministerium für Landwirtschaft, Naturschutz und Umwelt 2006). Eine Extrapolation vom Projektgebiet auf das gesamte Bundesgebiet ist naturgemäß mit Unsicherheiten behaftet: Die Befragten leben nahe an einem Waldgebiet mit Europa-weiter Naturschutzbedeutung. Dafür liegt das durchschnittliche pro Kopf-Einkommen in Thüringen unter dem Bundesdurchschnitt. Hochgerechnet auf die gesamte Bundesrepublik ergäbe die im Projektgebiet ermittelte Zahlungsbereitschaft eine Summe von 600 Millionen $€$ pro Jahr.

Welche praktischen Konsequenzen könnten aus unseren Ergebnissen zur Zahlungsbereitschaft für ökosystemare Versicherungs-Dienstleistungen vor unbekannten Risiken gezogen werden?

- Die ermittelten Zahlungsbereitschaften können zusammen mit ökologischen Studien genutzt werden, um den Schaden des Eingriffs in ökologische Systeme besser beziffern zu können. Dies kann die Bewertung von Straßenbauprojekten ebenso betreffen wie die Ermittlung von Schäden nach der kürzlich ins deutsche Recht überführten EU-Umwelt-Haftungsrichtlinie.

- In der Landschaftsplanung bieten sich neue Argumentationsansätze. Da eine Zahlungsbereitschaft für die entsprechende Versicherungs-Dienstleistung nachgewiesen wurde, kann ökosystemaren Kriterien nun eine höhere Bedeutung für die Etablierung und Ausgestaltung von Ausgleichsräumen zukommen. Etwa könnte rechtlich normiert werden, dass kein Indikator der Selbstorganisationsfähigkeit 
ökologischer Systeme (z.B. Kutsch et al. 2001) im Mittel der betrachteten Räume sinken soll.

Richten wir abschließend die Frage nach den praktischen Konsequenzen an eine moderne Pythia: „Wie sollen wir mit den ermittelten Zahlungsbereitschaften angesichts unbekannter Gefährdungen umgehen?“ - „Lege das Geld gut an!“ könnte die Antwort sein. Angesichts von bereits an den internationalen Börsen gehandelten „Katastrophen-Anleihen“ scheint jedem Investment-Krösus klar, was das bedeutet: Eine möglichst Rendite-trächtige Anlage in einem diversifizierten Portfolio an Wertpapieren (Heal 1998). Leider droht hier Pythias Rache. Da es sich bei den Pythia und Pandora-Risiken um Gefahren handelt, die potentiell katastrophenträchtige Folgen haben, ist es mit einer finanziellen Absicherung gegen diese Risiken etwa auf den internationalen Kapitalmärkten nicht getan. Hinreichend große Störungen menschlicher Konsum- und Produktionsprozesse voraus gesetzt, muss nämlich im schlimmsten Fall mit dem Zusammenbruch der Geldökonomie gerechnet werden (Barkmann \& Marggraf 2007). Die bislang gerade noch abgewundene Kernschmelze des internationalen Finanzsystems zeigt deutlich, wie bereits eine ökologisch gesehen marginale Katastrophe den Wert vertiefter Forderungen verdampfen lässt. Wie auch immer, ein ökologisch aufgeklärter Profi für Anlage in Naturkapital würde die in unserer Studie festgestellten Zahlungsbereitschaften für eine Stärkung der ökosystemaren Grundlagen unseres Wirtschaftens einsetzen. Eine Orientierung bieten hier beispielsweise Studien zur ökonomisch optimierten Auswahl von internationalen Natur-Schutzgebieten. Auch hier gibt es keine Garantie, großen Katastrophen zu entgehen. Aber deratige „Akzeptor-seitige“ Strategien sind angesichts fundamental unbekannter Risiken vergleichsweise alternativlos, um Pythias Rache soweit wie möglich zu entgehen. 


\section{Literaturverzeichnis}

Abs C (2004) Gebietsfremde Pflanzenarten der Waldbodenvegetation. Accessed 8 August 08 www.waldwissen.net/themen/waldschutz/invasive_neue_arten/lwf_fremde_pflanzen_ waldboden_2004_DE

Adamowicz WL, Boxall P, Williams M, Louviere J (1998) Stated Preference Approaches for measuring passive use values: Choice Experiments and Contingent Valuation.

American Journal of Agricultural Economics 80:64-75

Balser TC, Kinzig AP, Firestone MK (2002) Linking Soil Microbial Communities and Ecosystem Functioning. In: Kinzig AP, Pacala SW, Tilman D (eds) The Functional Consequences of Biodiversity. Princeton University Press, Princeton, Oxford, p 265293

Barkmann J, Baumann R, Meyer U, Müller F, Windhorst W (2001a) Ökologische Integrität: Risikovorsorge im nachhaltigen Landschaftsmanagement. Gaia 10:97-108

Barkmann J, Baumann R, Meyer U, Müller F, Windhorst W (2001b): On the Role of Ecosystem Self-organisation in Landscape Management: A Response. Gaia 10:247248

Barkmann J, Marggaf R (2004) The long-term protection of biological diversity. Lessons from market ethics: Poesis and Praxis. International Journal of Ethics and Technology Assessment 3:3-21

Barkmann J, Marggraf R (2007) Weil wir Geld nicht essen können: zur ökologischen Katastrophenvorsorge durch biologische Vielfalt. In: Sandhoff K, Engel A, Ertl G, Linsenmair KE, Nüsslein-Volhard C, Sackmann E, Schwab W, Donner ME, Stetter J (eds) Vom Urknall zum Bewusstsein: Selbstorganisation der Materie. Georg Thieme, Stuttgart, p 175-192

Baumgärtner S (2007) The Insurance Value of Biodiversity in the Provision of Ecosystem Services. Natural Resource Modeling 20:87-127

Freibauer A, Schulze ED (2005) Effizienz von Kohlenstoffsenken unter dem Aspekt des Klimaschutzes. Accessed 5 June 08 www.waldundklima.net/wald/freibauer_senkeneffizienz_01.php

Guckland A, Brauns M, Flessa H, Thomas FM, Leuschner C (2008) Acidity, nutrient stocks and organic matter content in soils of a temperate decidous forest with different abundance of European beech (Fagus sylvatica L.). Journal of Plant Nutrition and Soil 
Science (in press)

Hensher D, Rose J, Greene W (2005) Applied choice analysis: a primer. Cambridge University Press, Cambridge

Indermühle M, Raetz P, Volz R (2005) "Lothar" - Ursächliche Zusammenhänge und Risikoentwicklung. Accessed 11 August 08 www.waldwissen.net/themen/ naturgefahren/krisenmanagement/wsl_lothar_zusammenhaenge_DE

Jaeger J (2000) Zur Unterscheidung zwischen verschiedenen Arten von Unsicherheit bei der

Bewertung von Landschaftseinheiten. In: Jax K (ed) Funktionsbegriff und Unsicherheit in der Ökologie. Peter Lang Europäischer Verlag der Wissenschaften, Frankfurt am Main, Berlin, Bern, Bruxelles, New York, Oxford, Wien, p 115-137

Keil R (2002) Artendiversität als ökosystemare Versicherung gegenüber

Umweltveränderungen. In: Bundesamt für Naturschutz (ed) Treffpunkt Biologische Vielfalt II. Bonn, p 163-169

Knohl A, Schulze ED, Kolle O, Buchmann N (2003) Large carbon uptake by an unmanaged 250-year-old deciduous forest in Central Germany. Agricultural and Forest Meteorology 118:151-167

Kowarik I (2003) Biologische Invasionen. Neophyten und Neozoen in Mitteleuropa. Ulmer, Stuttgart

Kutsch WL, Steinborn W, Herbst M, Baumann R, Barkmann J, Kappen L (2001)

Environmental Indication: A Field Test of an Ecosystem Approach to Quantify Biological Self-Organization. Ecosystems 4:49-66

Law R, Weatherby AJ, Warren PH (2000) On the invasibility of persistent protest communities. Oikos 88:319-326

Liebe U (2007) Welchen Nutzen stiften kollektive Umweltgüter? Grundlagen und Anwendungen der Methodik der Choice Experimente. Accessed 8 August 08 www.uni-konstanz.de/hinz/Vortrag_uliebe_2007.pdf

Loreau M, Downing A, Emmerson M, Gonzalez A, Hughes J, Inchausti P, Joshi J, Norberg J, Sala O (2002) A new look at the relationship between diversity and stability. In: Loreau M, Naeem S, Inchausti P (eds) Biodiversity and Ecosystem Functioning, Synthesis and Perspectives. Oxford University Press, Oxford, New York, p 79-91

McCann KS (2000) The diversity-stability debate. Nature 405:228-232

Moore JL, Mouquet N, Lawton JH, Loreau M (2001) Coexistence, saturation and invasion resistance in simulated plant assemblages. Oikos 94:303-314 
Mund M (2004) Carbon pools of European beech forests (Fagus sylvatica) under different silvicultural management. PhD dissertation, Georg-August-Universität Göttingen, Germany

Perrings C (1995) Biodiversity conservation as insurance. In: Swanson TM (ed) The economics and ecology of biodiversity decline: The forces driving global change. Cambridge Unversity Press, New York, p 69-77

Potschin MB, Haines-Young R (2001) Are landscapes self-organising? Gaia 10:1-16

Rajmis S, Barkmann J (2007) Utilisation of Grounded Theory Methodology for the development of a choice experiment: Preliminary studies on the insurance value of biodiversity. In: Meyerhoff J, Lienhoop N, Elsasser P (eds) Stated Preference Methods for Environmental Valuation: Applications from Austria and Germany. Metropolis, Marburg p 175-202

Rajmis S, Barkmann J, Marggraf R (2009) Forest-management measures to mitigate climate change or adapt to its effects: monetary preferences in the user community around Hainich National Park, Germany (accepted for Climate Research)

Robertson GP, Vitousek PM (1981) Nitrification potentials in primary and secondary succession. Ecology 62:376-386

Schmidt O (2005) Zur Gefährdung der Hauptbaumarten aus Sicht des biotischen Waldschutzes. Accessed 8 August 08 www.waldwissen.net/themen/waldschutz/ lwf_biotische_gefahr_hauptbaumarten_2005_DE.

Schützendübel A, Polle A (2002) Plant responses to abiotic stresses: heavy-metal induced oxidative stress and protection by mycorrhization. Journal of Experimental Botany 53: $1351-1365$

Schwab G (1974) Sagen des klassischen Altertums. Ueberreuter, Wien

Sobek S, Scherber C, Steffan-Dewenter I, Tscharntke T (submitted) Sapling herbivory, herbivores and predators across a natural tree diversity gradient in Germany's largest deciduous forest. Submitted to Oecologia

Tilman D, Wedin D, Knops J (1996) Productivity and sustainability influenced by biodiversity in grassland ecosystems. Nature 379:718-720

Tilman D (1999) The ecological consequences of changes in biodiversity: a search for general principles. Ecology 80: 1455-1474

Thüringer Ministerium für Landwirtschaft, Naturschutz und Umwelt (2006) Forstbericht 
2006. Thüringer Druckhaus Gast \& Frisch GmbH, Eisenach

UNEP [United Nations Environment Programme] (2003) Millennium Ecosystem Assessment:

Ecosystems and Human Well-being. Island Press, Washington, Covelo, London

UNFCCC [United Nations Framework Convention on Climate Change] (2006) Millennium

Development Goals Indicators. Accessed 24 June 08

http://mdgs.un.org/unsd/mdg/Data.aspx

WBGU [Wissenschaftlicher Beirat der Bundesregierung Globale Umweltveränderungen] (1999) Jahresgutachten 1998. Strategien zur Bewältigung Globaler Umweltrisiken. Springer, Berlin, Heidelberg, New York (available in English)

Yachi S, Loreau M (1999) Biodiversity and ecosystem productivity in a fluctuating environment: the insurance hypothesis. Proceedings of the National Academy of Sciences of the U.S.A. 96:1463-1468 


\title{
Chapter $\mathbf{V}^{*}$
}

\section{A cost-benefit analysis of controlling Giant Hogweeds (H. mantegazzianum) in Germany}

\author{
Sandra Rajmis, Jan Thiele and Rainer Marggraf
}

Abstract: The development of realistic control programmes with respect to cost-benefit aspects is one aim of the European Strategy on Invasive Alien Species (Genovesi and Shine 2003). With ratification of the Rio Declaration, Germany is committed to control any further spread of invasive species (UNEP 2008). The paper analyses possible control options limiting stands of Giant Hogweeds (Heracleum mantegazzianum) in Germany (based on survey data of $\mathrm{n}=287$ districts; see Thiele and Otte 2008), focussing on cost-benefit aspects. We differentiate between several control options depending on infested area size (e.g. root destruction, mechanical cutting or mowing, chemical treatment and grazing) and protection status. The calculation of benefits is based on stated preference results (choice experiment $(\mathrm{CE}) ; \mathrm{n}=282$ ). For the cost side, we calculate two different invasion scenarios (i) no reinfestation after successfully conducted control measures (optimistic) and (ii) re-infestation twice after conducting control measures occurring within ten years (pessimistic). Costs result in a total of $6,498,036 €$ for optimistic invasion scenario and $11,280,621 €$ for pessimistic scenario. Benefits for invasion control in Germany result in a total of 238,063,641 $€$.

Keywords: Invasive species, giant hogweeds, cost-benefit analysis, willingness-to-pay, choice experiment $(\mathrm{CE})$, non-market valuation

\footnotetext{
* This manuscript is formatted for submission to 'Environmental Management'
} 


\section{Introduction}

Invasive species are considered to be a primary direct driver of biodiversity loss across the globe (UNEP 2008). Results of invasion experiments indicate that loss of species may have profound effects on the integrity and functioning of ecosystems (see e.g. Knops et al. 1999, Mwangi et al. 2007, van Ruijven et al. 2003, and Pfisterer et al. 2004). In addition, invasive species cause public health concern Chapter V Economic damages are reported as well (Nehrbass and Winkler 2007). A cost-benefit

H. mantegazzianum is origin analysis of controlling cies of the sub-alpine zone in the Western Greater Caucasus. It was introduced to central and Western Europe as an ornamental plant in the $19^{\text {th }}$ century (Pyšek 1991, Ochsmann 1996). Hunters used it as coverage and beekeepers as fodder plant (Westhus et al. 2006). Currently, H. mantegazzianum is spread all over Europe (Tiley et al. 1996); and in Germany, H. mantegazzianum currently occupies 57 \% of grid cells of the national floristic map (German National Floristic Database 2008).

H. mantegazzianum is often regarded as per se dominant species which locally suppresses native species (Thiele and Otte 2008). However, field studies in Germany ${ }^{18}$ revealed a high variability of cover-abundances; about one third of surveyed stands were dominant $^{19}$ with cover-abundances exceeding 50\% (Thiele and Otte 2008). $H$. mantegazzianum occurs in a variety of different habitat types, such as grasslands, roadsides, riverbanks, woodland margins (Thiele and Otte 2006). The highest invasion percentage (18.5\%) was found for abandoned grasslands, margins of grasslands and fields, and tall-forb stands (Thiele and Otte 2008). Open stands generally prevailed over dominant ones and single stands with sizes between 100 and $1000 \mathrm{~m}^{2}$ occurred most frequently (145 of 233 stands)

\footnotetext{
18 The quoted field studies were conducted in 2001 at 16 German sites at the western low mountain ranges (Thiele and Otte 2008).

19 The observed limitations indicate only partly dominant stands in the future, namely those representing early habitat invasion and disturbances or land-use change (Thiele and Otte 2008).
} 


\section{Chapter V}

while stands larger than $1000 \mathrm{~m}^{2}$ were found as minority (32 of 233 stands) (Thiele and Otte 2008).

H. mantegazzianum has negative impacts on human health, native biodiversity, and tourism (European and Mediterranean Plant Protection Organization - EPPO 2006, Schepker 1998). The plant is a serious health hazard because it exudes a clear watery sap, containing several photosensitizing agents (furanocoumarins or furocoumarins) which cause burnings of the skin in combination with daylight (Drever and Hunter 1970, Hipkin 1991). In addition, several furanocoumarins have been reported to cause cancer and malformations in the growing embryo (Nielsen et al. 2005). H. mantegazzianum causes erosion at riverbanks (Pyšek 1991). The species constrains public accessibility of sites, amenity areas, and trails (Tiley and Philp, 1994).

One aim of the European Strategy on Invasive Alien Species is to develop monitoring programmes based on cost-benefit-analyses (Genovesi and Shine 2003). Appropriate monitoring needs to be planned to reduce density and abundance of invasive species to keep its impact to an acceptable level in the long term (Genovesi and Shine 2003).

However, life-cycle variation between stand types makes it difficult to infer simple management rules (Hüls et al. 2007). Small and open stands of $H$. mantegazzianum may eventually serve as initiators for further spread after land-use changes, whereas dense stands might be stable (Hüls et al.). Westhus et al. (2006) suggest eradication of single plants or initial populations to prevent invasion of the whole area or district. Managing the growth of H. mantegazzianum, especially in the subpopulations with low individual density is reasonable (Hüls 2005). Mowing or grazing is an effective instrument to prevent growth and any further development stages (Hüls 2005). 


\section{Infestation control measures of $\boldsymbol{H}$. mantegazzianum}

\section{$2.1 \quad$ Natural control}

Models and simple laboratory experiments indicate that increasing community diversity increases resistance towards invasions (Law et al. 2000; Moore et al. 2001). Manipulative experiments confirm this relationship mostly (Knops et al. 1999, Pfisterer et al. 2004, van Ruijven et al. 2003, Naeem et al. 2000; Kennedy et al. 2002). Crawley et al. (1999) showed that in productive, small-scale grassland plots, species identity matters more than species richness in determining both the number and the total biomass of invading species. Recent studies indicate that diversity of functional groups (Kahmen et al. 2005, Mwangi et al. 2007) might be more important than pure species numbers. Invasion resistance of experimental plant communities might be related to the degree of niche overlap between resident species and invaders (Mwangi et al. 2007).

\subsection{Mechanical control}

Hand pulling is effective with young seedlings but not feasible with larger plants (EPPO 2006). Milling machines are beneficial for dominant or large populations (Westhus et al. 2006). Mowing two or three times during the season (May-June) hinders re-sprouting plants from setting seeds (EPPO 2006). Westhus et al. (2006) suggest eradication of single plants and small populations by cutting the root 10 to $15 \mathrm{~cm}$ under the earth's surface e.g. in springtime or digging them completely out. Root cutting is relatively labor intensive and timeconsuming, especially at inaccessible areas (e.g. riverbanks) but in return, this measure is highly effective and suitable for single plants or small stands (Nielsen et al. 2005). 


\subsection{Grazing}

Frequent mowing and grazing at appropriate stocking rates starting in mid spring (small plants) prevents flowering and seed set (Westhus et al. 2006). Experience with livestock grazing has been gained mainly from sheep, but $H$. mantegazzianum is also palatable to cattle (Lucey 1994). Intensive grazing, especially by sheep, is highly effective (Tiley et al. 1996). Sheep were found to greatly reduce the weed after 2 years of grazing and after 5 additional years the complete elimination of the weed could be achieved (Andersen and Calov 1996). Ten years of grazing are suggested by Nielsen et al. (2005). The effect of grazing is similar to cutting. In general, livestock needs a period of time to adapt to the hogweed before it regularly grazes the plants. Grazing is very efficient mainly for control of large stands and areas inaccessible to machinery.

\subsection{Chemical control}

The herbicide glyphosate is the compound most widely used against $H$. mantegazzianum (Niesar and Geisthoff 1999, Meinlschmidt and Dittrich 2005, Nielsen et al. 2007, EPPO 2006). Best results are achieved by applying the herbicide at the beginning of the vegetation period and a second time in July using a $5 \%$ or $3 \%$ dilution. Non-target effects can be minimized by treatment in early spring when surrounding vegetation has not yet developed. Application of glyphosate beyond agricultural fields or areas used for forestry has to be permitted by the responsible nature conservation agency in charge (Article 6 (2) and (3) of German Plant Protection Act). Chemical control is very effective because it causes close to $100 \%$ mortality. It is applicable at any invasion degree, but preferable for small plants. All herbicides recommended for control of $H$. mantegazzianum must be applied early in the season (March-May) for best effect. Treatment with glyphosate needs to be combined with 


\section{Chapter V}

effective re-vegetation of the site to prevent $H$. mantegazzianum seedlings from re-infesting the area (Noxious Weed Control Program 2003).

\section{Application of infestation control measures}

The Germanwide distribution and population density of $H$. mantegazzianum differs from district to district. A meaningful differentiation of infested areas is to identify the stands according to size and protection status. We distinguish small (up to $100 \mathrm{~m}^{2}$ ), medium ( $>100$ $\left.1000 \mathrm{~m}^{2}\right)$ und large $\left(>1000 \mathrm{~m}^{2}\right)$ area sizes and differentiate between protected (nature reserves) and unprotected areas (Thiele and Otte 2008). A range of possible control measures (manual, mechanical, chemical and gazing) is identified and shown in Table 1. The crosses (X`s) in Table 1 indicate appropriate and meaningful applications of infestation control measures.

Suggested measures for control of $H$. mantegazzianum at unprotected areas are root destruction with shovel (small areas), mechanical cutting with a scythe (medium areas) or flail mower (large areas). Regarding chemical control, herbicide spreaders (hand-held equipment) are suitable for small (up to $100 \mathrm{~m}^{2}$ ) and medium $\left(>100-1000 \mathrm{~m}^{2}\right.$ ) areas, and tractors with spraying machines for large areas $\left(>1000 \mathrm{~m}^{2}\right)$. Chemical treatment covers the cost of restoration ${ }^{20}$. Grazing is proposed for medium and large areas where suitable conditions for livestock farming are given with regard to soil, relief, climatic conditions, and ideally already existing livestock on neighbouring pastures. For protected areas (nature reserves), where chemical control is prohibited by law, we suggest root destruction with shovel (small areas) and mechanical cutting with scythe (medium and large areas).

\footnotetext{
${ }^{20}$ Restoration covers the cost of sowing machines, seeds, ploughing, sowing, and working hours (70€ per year and hectare)
} 


\section{Chapter V}

Table 1. Application of control measures to limit $H$. mantegazzianum depending on size and protection status of infested areas

\begin{tabular}{|c|c|c|c|c|c|c|}
\hline Area size & $\begin{array}{l}\text { Root } \\
\text { destruction } \\
\text { with shovel } \\
\text { (manually) } \\
\end{array}$ & $\begin{array}{l}\text { Mechanical } \\
\begin{array}{l}\text { cutting with } \\
\text { scythe }\end{array}\end{array}$ & $\begin{array}{l}\text { Mechanical } \\
\text { cutting } \\
\text { with flail } \\
\text { mower } \\
\end{array}$ & $\begin{array}{l}\text { Chemical } \\
\text { treatment with } \\
\text { hand-held } \\
\text { equipment } \\
\end{array}$ & $\begin{array}{l}\text { Chemical } \\
\text { treatment } \\
\text { with } \\
\text { machines } \\
\end{array}$ & $\overline{\text { Grazing }}$ \\
\hline \multicolumn{7}{|c|}{ Unprotected areas } \\
\hline $\begin{array}{l}\text { Small } \\
\text { (up to } 100 \mathrm{~m}^{2} \text { ) }\end{array}$ & $\mathrm{X}$ & - & - & $\mathrm{X}$ & - & - \\
\hline $\begin{array}{l}\text { Medium } \\
\left(>100-1000 \mathrm{~m}^{2}\right)\end{array}$ & - & $\mathrm{X}$ & - & $\mathrm{X}$ & - & $\mathrm{X}$ \\
\hline $\begin{array}{l}\text { Large } \\
\left(>1000 \mathrm{~m}^{2}\right)\end{array}$ & - & - & $\mathrm{X}$ & - & $\mathrm{X}$ & $X$ \\
\hline \multicolumn{7}{|c|}{ Protected areas (nature reserves) } \\
\hline Small & $\mathrm{X}$ & - & - & - & - & - \\
\hline Medium & - & $\mathrm{X}$ & - & - & - & - \\
\hline Large & - & $X$ & - & - & - & - \\
\hline
\end{tabular}

The varying workload and efficacy (frequency of treatments) of the possible control measures is shown in Table 2. Nielsen et al. (2005) estimated the workload for root destruction with shovel (manually) with 100 plants per hour and one treatment. Mechanical cutting with a scythe is estimated using 500 plants per hour and three treatments. Estimated workload for mechanical cutting with flail mower is about 0.5 ha per hour or 1000 plants and three treatments. For chemical control by hand-held equipment, the authors estimate a workload of 100 plants and two treatments. Chemical treatment with machines is estimated with about 0.5 ha per hour or 1000 plants per hour and two treatments. It must be considered that chemical control (e.g. glyphosate) has several restrictions (see above, chapter 2.4). Grazing is a 'continuous treatment' and includes the workload for fencing and maintenance. 


\section{Chapter V}

Table 2. Estimated workload and efficacy of different control measures according to Nielsen et al. (2005)

\begin{tabular}{lll}
\hline \hline Control methods & Workload & $\begin{array}{l}\text { Efficacy/frequency } \\
\text { of treatments }\end{array}$ \\
\hline \hline $\begin{array}{l}\text { Root destruction with shovel } \\
\text { (manually) }\end{array}$ & Estimated time for control: 100 plants/hour & One \\
\hline Mechanical cutting with scythe & Estimated time for control: 500 plants/h & Three \\
\hline $\begin{array}{l}\text { Mechanical cutting with flail } \\
\text { mower }\end{array}$ & 0.5 ha/1000 plants/hour & Three \\
\hline $\begin{array}{l}\text { Chemical control with hand held } \\
\text { equipment }\end{array}$ & Estimated time effort: 100 plants $/ \mathrm{h}$ & Two \\
\hline Chemical treatment with machines & Estimated time effort: 0.5 ha/ 1000 plants $/ \mathrm{h}$ & Two \\
\hline Grazing & $\begin{array}{l}\text { Fencing: 4-wire electric wire fencing } \\
\text { Maintenance: Yearly inspection of the fence, other } \\
\text { inspections }\end{array}$ & $\begin{array}{l}\text { 'Continuous' } \\
\text { treatment }\end{array}$ \\
\hline \hline
\end{tabular}

\section{Methods}

\subsection{Cost-benefit analysis}

Cost-benefit analysis aims to quantify the value of all positive and negative consequences of a project to all members of society in monetary terms. The positive consequences result from the project goal. To reach this goal resources such as labour, tax revenues or natural capital have to be employed. These resources are no longer available for other purposes - an undesired negative consequence of the project. Further negative consequences may occur if the project has unintended secondary effects. The monetary value of the positive (negative) consequences is called benefits (costs). Usually, benefits and costs accrue over extended periods (years).

From today's point of view all resources available in the future are less valuable than those available today. Therefore, in CBA future benefits (costs) are discounted relative to present benefits (costs) to obtain their present values. A benefit (cost) that occurs in year $t$ is converted to its present value by dividing it by $(1+d)^{t}$ where $d$ is the social discount rate. 


\section{Chapter V}

So if a project has a duration of $n$ years with yearly benefits $\left(B_{t}\right)$ and costs $\left(C_{t}\right)$ the present value of the benefits $(P V(B))$ is $P V(B))=\sum_{i=0}^{n} B_{t} /(1+d)^{t}$ and the present value of the costs $(P V(C))$ is $P V(C)=\sum_{i=0}^{n} C_{t} /(1+d)^{t}$. If the present value of the benefits exceeds the present value of the costs the project is valued positively because it leads to a more efficient allocation of society's resources. This means a project should be implemented if the ratio

$P V(B) / P V(C)=\left[\sum_{i=0}^{n} B_{t} /(1+d)^{t}\right] /\left[\sum_{i=0}^{n} C_{t}(1+d)^{t}\right]$

is greater than one.

To identify if present values of benefits of infestation control measures exceed the present values of costs we oppose benefits ('willingness to pay' (WTP); see chapter 4.3) from an empirical face-to-face survey to the costs of control measures limiting stands of $H$. mantegazzianum depending on infested area size in each German district (see chapter 3 and Annex). We assume that WTP of respondents includes the benefits for control measures for the entire time period of measure implementation.

We assume a nationwide distribution of H. mantegazzianum based on German National Floristic Database (2008). Thus, costs and benefits used in the analysis refer to a nationwide implementation of control measures.

In detail assumptions for the calculation of costs are based on data from a nationwide survey in 2002/2003 (for details see Thiele and Otte 2008). The survey addressed the nature conservation authorities of German districts and cities independent from a district administration (Thiele and Otte 2008). The questionnaire included questions about the 


\section{Chapter V}

maximum spatial extent of single stands of $H$. mantegazzianum (up to $100 \mathrm{~m}^{2},>100-1000 \mathrm{~m}^{2}$, $>1000 \mathrm{~m}^{2}$ ) for different habitat types (e.g. roadside or forest margin; default list provided) and about occurrences in nature reserves per district or city. Because no conclusion of the total frequency of single stands per district or city could be made, our calculations are based on the assumption of a minimum occurrence of the evaluated stands dependent on area size (up to $\left.100 \mathrm{~m}^{2},>100-1000 \mathrm{~m}^{2},>1000 \mathrm{~m}^{2}\right)$ per district or city. This means, the available data $($ of $\mathrm{n}=$ 287 districts and cities) indicate, if at least one small, medium or large area is infested and if at least one of these areas is protected. For the final result, the average benefit-cost relation of all districts is relevant ${ }^{21}$. For calculation of workload costs and control methods, we follow suggestions of Nielsen et al. (2005) (see Table 2). For the cost-benefit analysis, we chose the most reasonable measures with lowest costs for each area type (protected or not) and size (estimated infested area) (Table 1 and 4).

\subsection{Calculation of benefits}

The calculation of benefits is based upon an empirical face-to-face survey including results of a CE (stated preference method see e.g. Adamowicz et al. 1998, Bateman et al. 2002). Attending the CE respondents had to state their WTP for 'hypothetical' control measures limiting stands of $H$. mantegazzianum. In the questionnaire, we give a short definition of invasive plants especially of $H$. mantegazzianum. We inform respondents about health impacts of the species and potential negative impacts on native biodiversity and agriculture. A picture of the $H$. mantegazzianum was shown to the respondents. Within the $\mathrm{CE}$ the following two options were offered to respondents:

- Option 1: removal of invasive plants in particular cases for which negative effects are known, or

\footnotetext{
${ }^{21}$ Thus we abstain from calculation of average benefit-cost relation for districts where no data were available.
} 
- Option 2: removal of invasive plants in large areas even it is unclear if they have negative effects or not.

In the CE, respondents are asked to state their choice regarding the preferred option. Including the 'price' of the hypothetical measure each choice option indicates benefits of respondents obtained by the choices. In the econometric analysis, average WTP of respondents for the 'hypothetical' control measures is calculated. In our empirical study, we investigated WTP for three further environmental topics (see Rajmis et al. 2009a/b) included in the choice options.

Benefits are considered as one single payment opposed to costs including control measures limiting stands of $H$. mantegazzianum for a period of ten years. In the following analysis empirical benefit results are calculated as direct-use value per household and multiplied with the number of households in each German district accounting for nationwide control measures.

As sensitivity analysis, we recommend calculating switching values and overestimation factors indicating the reliability of hypothetical WTP results (compare Bräuer and Suhr 2005).

\subsection{Calculation of costs}

For the cost side, we calculate two different invasion scenarios for each area size, type and measure (see Table 4): (i) no re-infestation after successfully conducted control measures (optimistic) and (ii) re-infestation twice after conducting control measures within ten years (pessimistic). For the following cost-benefit analysis, we chose the measures with lowest costs for each area type (protected or not) and size (estimated infested area) (Table 1 and 4).

We suggest yearly discount rates (material costs) of $6 \%$ and yearly inflation rates of $3 \%$. Additionally, $1 \%$ increase in labour costs per year is assumed. All costs include $50 \%$ additional costs for after-treatment and 30\% additional costs for monitoring (30\% of labour 


\section{Chapter V}

costs) for each year. For agricultural background information and calculations, we use the software KTBL 2006.

Table 3. Basic assumptions for calculations of labour and material costs of different control methods to limit $H$. mantegazzianum. Changed after Nielsen et al. (2005)

\begin{tabular}{lll}
\hline \hline $\begin{array}{l}\text { Description of } \\
\text { measure }\end{array}$ & Cost of labour & Cost of materials \\
\hline \hline $\begin{array}{l}\text { Root destruction } \\
\text { and mechanical } \\
\text { cutting }\end{array}$ & $\begin{array}{l}33 € \text { per hour; additional job training of 5 hours, } \\
\text { one treatment and one after-treatment }\end{array}$ & $\begin{array}{l}\text { Protective clothing, shovel, } \\
\text { scythe, flail mower, machine } \\
\text { repair }\end{array}$ \\
\hline $\begin{array}{l}\text { Chemical } \\
\text { treatment }\end{array}$ & $\begin{array}{l}\text { two treatments, restoration (plough and seeder, planting } \\
\text { costs and two cuttings per year) }\end{array}$ & $\begin{array}{l}\text { Protective clothing, machines, } \\
\text { herbicide spreader, diesel and } \\
\text { machine oil, technical inspection } \\
\text { and machine check, machine } \\
\text { repair, glyphosate }\end{array}$ \\
& & $\begin{array}{l}\text { Fencing, purchase of animals, } \\
\text { shelter, water supply, additional } \\
\text { fodder, veterinary inspection and } \\
\text { treatment }\end{array}$ \\
& $\begin{array}{l}33 € \text { per hour; maintenance of fencing, periodic } \\
\text { inspection, daily inspection of animals, moving of } \\
\text { animals between fenced area, scrub removal, branch } \\
\text { pruning, building of stiles, supplementary cutting of } \\
\text { H.mantegazzianum outside the fencing with 1000 hours } \\
\text { per year and administration with 15 hours per site and } \\
\text { year }\end{array}$ & \\
\hline \hline
\end{tabular}

$33 €$ per hour are calculated as costs of labour for all measures. For root destruction measures of $H$. mantegazzianum, additional job training of 5 hours for instruction are considered. One worker is suggested for every small area (up to $100 \mathrm{~m}^{2}$; average $50 \mathrm{~m}^{2}$ ), ten workers for every medium area ( $>100-1000 \mathrm{~m}^{2}$; average $\left.550 \mathrm{~m}^{2}\right)$, and five workers for every large area using machines $\left(>1000 \mathrm{~m}^{2}\right.$; average $\left.5500 \mathrm{~m}^{2}\right)$. We considered establishment costs for protective clothing, shovel, scythe and flail mower. Running costs include monitoring (30\% of labour costs) and two additional treatments, plus repair costs for machines (e.g. flail mower).

Costs for chemical control include two treatments per area, protective clothing (safety glasses, (mouth-) mask, cap, coat and trousers, shoes and gloves), herbicide spreader for small and medium areas and tractor with spraying machine for large areas, diesel and machine oil, technical inspection and machine check, glyphosate concentrate, restoration (seed mixture, e.g. $70 \%$ grass, $30 \%$ herbs, 4000 seeds or 20 g per $\mathrm{m}^{2}$; planting costs, two cuttings per year), 


\section{Chapter V}

plough and seeder. Besides working hours for the described measures, we add five hours for job training for each area. Establishment costs for chemical control include protective clothing, shovel, scythe, machines (tractor with spraying machine, plough, and seeder), herbicide spreader, glyphosate and seeds for restoration. Running costs for chemical control are for diesel and machine oil, technical inspection agency and machine check.

Grazing (see Nielsen et al. 2005, Andersen and Calov 1996) is suggested for medium $\left(>100-1000 \mathrm{~m}^{2}\right)$ and large $\left(>1000 \mathrm{~m}^{2}\right)$ infested areas. Considering sheep having to get used to H. mantegazzianum, we included an additional $5 \%$ of total costs for initiation of the measure. We consider establishment costs as those associated with the purchase of animals, fencing with a lifespan of 10 years and shelter. Running costs include maintenance of fencing, periodic inspection, daily inspection of animals and moving of animals between fenced areas as well as supplementary cutting of $H$. mantegazzianum outside the fenced area, in total, 1000 hours ( $33 €$ per hour) workload per year. Additionally, we calculate 15 hours in administrative costs per area and year. Furthermore, additional fodder as well as veterinary inspection and treatment and water supply are considered. Thirty percent of total costs are suggested for yearly monitoring. Costs of labour are calculated with three people for medium areas (average $550 \mathrm{~m}^{2}$; by maximum $1,000 \mathrm{~m}^{2}$ ) and 5 people for large areas (average $5,500 \mathrm{~m}^{2}$; by maximum $\left.10,000 \mathrm{~m}^{2}\right)$.

All costs are borne and financed by the public authority, thus we include additional taxes (access burden) at the rate of $15 \%$ in the cost calculation. 


\section{Results}

\subsection{Benefits from control measures}

The CE study was conducted as a household survey using face-to-face interviews ${ }^{22}$ in central Germany. Of the successfully contacted 302 households 282 respondents completed the choice task (6.6\% protest answers). The main survey was preceded by qualitative preliminary studies $(\mathrm{n}=16)$, pre-test interviews (as mail survey and face-to-face; $\mathrm{n}=57$ ) and pilot study $(\mathrm{n}=106)$. An average interview took 35 minutes.

On average, respondents preferred the first option offered in the choice experiment: 'removal of invasive plants in particular cases for which negative effects are known', in other words the control of obviously 'dangerous' invasive plants such as H. mantegazzianum. Respondents stated a WTP of $8.96 €$ per person and year $(p<0.05)$ when compared to the more aggressive eradication program. Stated benefits were used for calculation of direct use values as one payment per household. Control of $H$. mantegazzianum is a significant predictor of choice within the econometric model $\left(\mathrm{p}<0.05\right.$; $\mathrm{Chi}^{2}<0.001$; Pseudo- $\mathrm{R}^{2}$-values of the base model are between 0.060 and 0.062 (Pseudo- $\mathrm{R}^{2}$-values between $0.06-0.07$ correspond to $\mathrm{R}^{2}$ values of $0.19-0.22$ of the linear model) (Hensher et al. 2005:338). For more details on the choice experiment method, the empirical study and further results see Rajmis et al. (2009b).

\subsection{Costs of control measures}

Costs result in a total of $6,498,036 €$ for the optimistic invasion scenario and $11,280,621 €$ for the pessimistic invasion scenario. The cost details for suggested control measures of infested areas are displayed in Table 4 for one area per size and for a time-period of ten years. For an optimistic scenario in non-protected areas, 'minimum costs result in $791.20 €$ for small (root destruction with shovel; costs of labour with an after-treatment result in $204.70 €$, costs of

\footnotetext{
22 The questionnaire is available upon request.
} 


\section{Chapter V}

material with an after-treatment result in $171.35 €$ ), 5,092.20 € for medium (chemical treatment with hand-held equipment including restoration; costs of labour with an aftertreatment result in $632.50 €$, costs of material with an after-treatment result in $2,558.75 €$ ) and $44,299.15 €$ for large areas (mechanical cutting with flail mower; costs of labour with an after-treatment result in $3,568.85 €$, costs of material with an after-treatment result in 33,522.50 €). For a pessimistic scenario in non-protected areas minimum costs result in $1,460.50 €$ for small (root destruction with shovel), $10,683.50 €$ for medium (chemical treatment with hand-held equipment including restoration) and 48,739.30 € for large areas (grazing; costs of labour with after-treatment result in $759 €$; costs of material with an aftertreatment result in 7,917.75 €). For an optimistic scenario in protected areas, costs amount to $791.20 €$ for small areas (root destruction with shovel), 7,294.45 $€$ for medium areas (mechanical cutting with scythe) and 22,122.55 € for large areas (mechanical cutting with scythe). For a pessimistic scenario in protected areas costs result in $1,460.50 €$ for small (see above), $15,191.50 €$ for medium (see above) and $38,803.30 €$ for large areas.

\subsection{Benefit-cost relation of control measures}

The average benefit-cost relation of German districts for control measures of $H$. mantegazzianum is $37: 1$ for optimistic scenario and $21: 1$ for pessimistic scenario calculations for area sizes ranging between $100 \mathrm{~m}^{2}$ and by maximum $10,000 \mathrm{~m}^{2}$. Results indicate that every euro of calculated costs can be opposed to averagely $29 €$ of benefits. The calculated benefit-cost values are larger than one indicating that advantages of the project prevail (Marggraf 2005, Gans and Marggraf 1997). 


\section{Chapter V}

Table 4. Costs (net present value) for suggested control measures of infested sites for a time-period of ten years

\begin{tabular}{|c|c|c|c|c|c|c|c|}
\hline Area size & Scenario & $\begin{array}{l}\text { Root destruction } \\
\text { with shovel }\end{array}$ & $\begin{array}{l}\text { Mechanical } \\
\text { cutting with } \\
\text { scythe }\end{array}$ & $\begin{array}{l}\text { Mechanical } \\
\text { cutting with } \\
\text { flail mower }\end{array}$ & $\begin{array}{l}\text { Chemical treatment } \\
\text { with hand-held } \\
\text { equipment }\end{array}$ & $\begin{array}{l}\text { Chemical } \\
\text { treatment with } \\
\text { machines }\end{array}$ & Grazing \\
\hline \multicolumn{8}{|c|}{ Unprotected areas } \\
\hline & Optimistic $^{\&}$ & $791.20 €^{\#}$ & & & $2,789.90 €$ & & \\
\hline \multirow[t]{2}{*}{ Small } & Pessimistic & $1,460.50 €$ & & & $5,055.40 €$ & & \\
\hline & Optimistic & & $7,294.45 €$ & & $5,092.20 €$ & & \\
\hline \multirow[t]{2}{*}{ Medium } & Pessimistic & & $15,191.50 €$ & & $10,683.50 €$ & & $13,059.40 €$ \\
\hline & Optimistic & & & $44,299.15 €$ & & $129,306.00 €$ & \\
\hline \multirow[t]{3}{*}{ Large } & Pessimistic & & & $109,000.45 €$ & & $350,969.65 €$ & $48,739.30 €$ \\
\hline & & & otected areas & ature reserves) & & & \\
\hline & Optimistic & $791.20 €$ & & & & & \\
\hline \multirow[t]{2}{*}{ Small } & Pessimistic & $1,460.50 €$ & & & & & \\
\hline & Optimistic & & $7,294.45 €$ & & & & \\
\hline \multirow[t]{2}{*}{ Medium } & Pessimistic & & $15,191.50 €$ & & & & \\
\hline & Optimistic & & $22,122.55 €$ & & & & \\
\hline Large & Pessimistic & & $38,803.30 €$ & & & & \\
\hline
\end{tabular}

\#cheapest option for each area size is in bold

\&optimistic scenario: no re-infestation after successfully conducted control measures; pessimistic scenario: twice re-infestation within ten years

\section{Summary and conclusions}

This is the first cost-benefit analysis promoting societal importance of $H$. mantagezzianum invasion control in Germany. Using a choice experiment we estimate the benefits of giant hogweed control and perform a cost-benefit analysis of different control measures.

Our cost-benefit-analysis clearly shows that control measures limiting $H$. mantagezzianum in German districts are meaningful from an economic point of view. Indeed, at national level the proposed control measures indicate that advantages of hypothetical implementation prevail. Net present values of control measures of infested sites for a time period of ten years in our study range between $791.20 €$ and $350,969.65 €$ depending on area size, type of treatment (manual, mechanical, chemical or grazing) and number of treatments 


\section{Chapter V}

(see Table 2). Based on the literature (e.g. Nielsen et al. 2005), we opposed control costs of ten years to benefits from one payment.

The described control measures e.g. chemical control also might have negative impacts on other species (Singh and Shaner 1998), on humans e.g. health impacts (Richard et al. 2005) and economic impacts (Vila et al. 2009). If and to what extent costs of these impacts (and secondary impacts e.g. insect resistance) may appear, is beyond the scope of this paper (Cerdeira and Duke 2006; see also Meyerhoff and Hartje 2006).

There are few studies about costs and benefits of invasion control. Carlsson and Kataria (2006) assessed management options for an invasive water weed (yellow floating heart; Nymphoides peltata) in Sweden using a choice experiment. Removing the weed in specific areas in the lake (Väringen) passed the cost-benefit test (housing area, bathing place, canoe track and boat place), in the remaining areas did not. Carlsson and Kataria (2006) estimated $564.70 €^{23} / \mathrm{ha} / \mathrm{yr}$ as the average control cost. The authors calculate two treatments per year (no re-infestation). The cost results are quite similar to our calcultions, cost of mechanical cutting, two treatments, and optimistic assumption (no re-infestation) (Annex Table 3). Our cost including $15 \%$ access burden result in $653.20 € / \mathrm{ha} / \mathrm{yr}$ taking year one to year nine as the average reference. Including the first year $\left(\right.$ year $\left._{0}\right)$, i.e. 10 years of treatment plus initiation costs, average costs amount to $4,371 € / \mathrm{ha} / \mathrm{yr}$. In both valuation studies non-use values are included. Based upon these results, we conclude that if no policy action were taken to prevent re-infestations in Geman districts, there would be a significant welfare loss.

Nunes and Markandya (2008) evaluated the economic value of damage caused by marine bio-invasions in the Netherlands and Italy. Using contingent valuation, Nunes and Markandya (2008) found a willingness to pay of $76 €$ per respondent and year for open access to the beach area of Zandvoort without harmful algae for the entire year. The authors also

${ }^{23} 56,000 \mathrm{SEK}$; at the time of the survey $1 \mathrm{USD}=7.6 \mathrm{SEK}$. 


\section{Chapter V}

identified that an individual fisherman is willing to accept $5,904 €$ for the first year to change fishing to an invasive clam (manila clam; Tapes philippinarum). The estimates can be interpreted as the lower bond of the total, unknown economic value of damage by marine bioinvasions (Nunes and Markandya 2008).

Panzacchi et al. (2007) accounted for costs of damage and control activities of Myocastor coypus in Italy and the UK. Here, benefits were identified as economic losses caused by coypu in Italy (damage to agriculture, prevention and management options) based on an administration survey. Coypu management in Italy from 1995 to 2000 results in $11,631,721 €$ of economic loss (9-12 milions/year). Results show that even very costly eradications, if successful, may have a very positive cost-benefit ratio in the long term (Panzacchi et al. 2007).

Kataria (2007) calculated a cost-benefit analysis for the introduction of the non-native signal crayfish (Pacifastacus leniusculus) in Sweden. The author used two bioeconomic models, in the first one he considered invasive species as pests, and in the second one he included the commercial value of the crayfish as well. The results indicate that the net benefit of an introduction is positive if the growth rate of the noble fish is below $40 \%$ that of the invasive signal crayfish.

Comparing costs and benefits of biological control of invasive plants (Lantana camara and Opuntia aurantiaca Lindley) in South Africa unveiled that the economic value of water accounted for $70 \%$ of the combined benefits (van Wilgen et al. 2004). Benefit-cost ratios for the historical analysis ranged from 8:1 for lantana (Lantana camara) to 709:1 for jointed cactus (Opuntia aurantiaca Lindley). The sensitivity analysis showed that the returns on investment in biological control research generally remain positive with some variations between species (van Wilgen et al. 2004). 


\section{Chapter V}

The studies mentioned above result in positive benefit-cost outcomes indicating that invasion control is paying off. Opposing costs and benefits clearly show: the control activities are economically reasonable. This might be a more convincing argument for policymakers than nature conservation as a good deed. Hence, it seems to be important to understand the economic perspective of invasion control. In some of the quoted studies only parts of societal benefits e.g. as damage prevention are considered (e.g. Panzacchi et al. 2007). Also monetary costs based on expert extrapolations (Collautti et al. 2006; Olson 2006; Lowell et al. 2006) make just one part of economic impacts visible. For policy implementation of conservation programs benefits of non-markets goods and services are also necessary requirements in terms of cost-benefit considerations (Vila et al. 2009).

If we want to take economics seriously in terms of nature conservation programs using cost-benefit analysis, first, non-use values need to be considered as part of the complete economic value society benefits from. Secondly, the issue of business and economics should not be mixed. Our study clearly shows that nature conservation by invasion control does pay off and that those economic considerations promote societal importance of natural science evidence. This study contributes estimates of the potential costs and benefits of invasion mitigation on the landscape level. Additionally, the importance of economic valuation studies - especially of non-market goods - is growing (Vila et al. 2009) particularly due to empty governmental cashes. For implementation of future conservation programs cost-benefitanalysis are a necessary requirement. Average yearly costs might increase if the current control policy does not change and if monitoring frequency is reduced (Breukers et al. 2008).

Economic valuation is often blamed for its hypothetical characteristics. How reliable are results of willingness to pay studies? How probable are biases in WTP-results? And how probable is overestimation in the range of the investigated benefits? 


\section{Chapter V}

To give consideration to these critical questions, we suggest potential overestimation of our empirically investigated benefits. It seems impossible to develop a unique calibration factor comparing hypothetical and real WTP but it is possible to compare our empirical WTP results with other empirical studies. Bräuer and Suhr (2005) evaluated 43 empirical studies comparing hypothetical and real WTP for various environemntal or biodiversity conservation programs. The authors stress the importance of potential overestimation suggesting the calculation of 'switching values'. 'Switching values' equal WTP amounts necessary for positive benefit-cost relations (Bräuer and Suhr 2005). WTP-amounts divided by 'switching values' identify maximum allowed overestimation (Bräuer 2002:264). For further details on this calculation, we have to refer to Bräuer and Suhr (2005).

Table 5. Switching value and overestimation factor

\begin{tabular}{lcc} 
Results & Optimistic calculation & Pessimistic calculation \\
\hline \hline Average benefit-cost relation of German districts & 36.6 & 21.1 \\
Switching value (in $€$ ) & 0.03 & 0.05 \\
Overestimation factor (WTP/ switching value) & 298.6 & 179.2 \\
\hline \hline
\end{tabular}

The average benefit-cost relation of German districts for control measures of $H$. mantegazzianum is 36.6 for optimistic and 21.1 for pessimistic scenario calculations (Table 5). Based on these results, we calculate 'switching values' and overestimation factors (WTP/switching value; see Table 5). In our study, respondents were willing to pay $8.96 €^{24}$ on average for control measures of H.mantegazzianum. This amount corresponds to the 180 -fold of the switching value in the pessimistic scenario being necessary for a reasonable benefitcost-result (Getzner 2001, Bräuer and Suhr 2005). This result seems quite convincing. But how probable are biases in the range of the calculated overestimation factor? The probability of biases is quite low because in the range of our overestimation indicator (Table 5) over 95\%

\footnotetext{
24 Protest answers corrected.
} 


\section{Chapter V}

of the evaluated studies comparing 'real' and hypothetical WTP show lower overestimation (Bräuer and Suhr 2005). Calculating overestimation (WTP/switching value) or net-benefit of measure implementation (Bräuer and Suhr 2005) we get a factor of 298.6 for optimistic and 179.2 for pessimistic scenario. This means, if our empirically investigated results would be overestimated by factors between 180 (pessimistic scenario) and 300 (optimistic scenario), 'necessary' real WTP would be still the amount of the switching values $(0.05 €$ and $0.03 €)$, hence high enough to keep the benefit-cost relation positive. Results of overestimation calculation might be seen as an indicator for the reliability of the empirical study. This clearly shows again that advantages of the proposed control measures prevail.

Suggestions for future control programs and policy scenarios might be to 1) intensify control efforts in the most vulnerable areas in terms of biodiversity loss and human activities considering health impacts of $H$. mantegazzianum (compare Panzacchi et al. 2007); 2) plan control policies at an adequate spatial scale taking into account potential re-infestations where the species is imminent or extant (compare Thiele and Otte 2008, Nielsen et al. 2005); 3) support research on effective control and prevention methods in different ecosystems (Panzacchi et al. 2007); 4) plan policy programs i) to conserve biodiversity at landscape level as invasion insurance especially in vulnerable ecosystems (Lanta and Leps 2008) ii) to constrain abundance were invasive plants once have successfully established (Levine et al. 2004); 5) identify areas where policies could negatively affect invasive-species management (compare Pyke et al. 2008); 6) incorporate further comprehensive accounting of non-market values (such as loss in aesthetic values of the rangelands and ecosystem services) related to invasion in future cost-benefit-analysis (compare Julia et al. 2007); and 7) support modeling approaches to compare costs and benefits of control measures (Breukers et al. 2008). 


\section{Acknowledgement}

We thank German Research Foundation (DFG Research Training Group 1086) for funding, our field assistants, the survey participants, J. Barkmann for providing valuable criticism on a previous version of this manuscript, M. Harcken for language editing.

\section{References}

Adamowicz W, Louviere J, Swait J (1998) Introduction to Attribute-Based Stated Choice Methods. Advanis Inc. for the National Oceanic and Atmospheric Administration, US Department of Commerce

Andersen UV, Calov B (1996) Long-term effects of sheep grazing on giant hogweed (Heracleum mantegazzianum). Hydrobiologia 340:277-284

Bateman IJ, Carson RT, Day B, Hanemann M, Hanley N, Hett T, Jones-Lee M, Loomes G, Mourato S, Özdemiroglu E, Pearce OBE DW, Sugden R, Swanson J (2002) Economic valuation with Stated Preference Techniques: A manual. Edward Elgar, Cheltenham, Northhampton

Bräuer I, Suhr A (2005) Ergebnisse von Zahlungsbereitschaftsanalysen: Interpretation und Verwendung. In: Marggraf R, Bräuer I, Fischer A, Menzel S, Stratmann U, Suhr A (eds.) Ökonomische Bewertung bei umweltrelevanten Entscheidungen. Metropolis, Marburg, p 149-183

Breukers A, Mourits M, van der Werf W, Lansink AO (2006) Costs and benefits of controlling quarantine diseases: a bio-economic modeling approach. Agricultural Economics 38:137-149

Carlsson F, Kataria M (2006) Assessing management options for weed control with demanders and non-demanders in a choice experiment. Working paper in Economics no. 208, Department of Economics, School of Business, Economics and Law, Göteborg University

Cerdeira AL, Duke SO (2006) The Current Status and Environmental Impacts of Glyphosate-Resistant Crops. Journal of Environmental Quality 35:1633-1658

Collautti RI, Bailey SA, van Overdijk CDA, Amundsen K, MacIsaac HJ (2006) Characterised and projected costs of nonindigenous species in Canada. Biological Invasions 8:45-49

Crawley MJ, Brown SL, Heard MS, Edwards GR (1999) Invasion-resistance in 
experimental grassland communities: species richness or species identity? Ecology Letters 2:140-148

Drever JC, Hunter JA (1970) Giant hogweed dermatitis. Scottish Medical Journal 15:315319

European and Mediterranean Plant Protection Organization (2006) EPPO data sheet on Invasive Plants. Accessed 8 August 08 www.eppo.org/QUARANTINE/ias_plants Gans O, Marggraf R (1997) Kosten-Nutzen-Analyse und ökonomische Politikbewertung. Springer, Berlin, Heidelberg

Genovesi P, Shine C (2003) European Strategy on Invasive Alien Species. Convention on the conservation of European wildlife and natural habitats. Council of Europe Publishing, Strasbourg

German National Floristic Data Base [Neoflora, BfN] (2008) Heracleum mantegazzianum Sommier \& Levier (Apiaceae), Riesen-Bärenklau. Accessed 10 August 08 www.floraweb.de/neoflora/handbuch/heracleummantegazzianum.html

Getzner M (2001) Zur Verwendung der Ergebnisse von Kontingenzbefragungen für Politikentscheidungen. In: Elsasser P, Meyerhoff J (eds) Ökonomische Bewertung von Naturgütern. Methodenfragen zur Kontingenten Bewertung und praktische Erfahrungen im deutschsprachigen Raum. Metropolis, Marburg, p 245-268

Hensher D, Rose J, Greene W (2005) Applied choice analysis: a primer. Cambridge University Press, Cambridge

Hipkin C (1991) Phytophotodermatitis. Botanical Society of the British Isles News 59:7-8 Hüls J (2005) Populationsbiologische Untersuchung von Heracleum mantegazzianum Somm. \& Lev. in Subpopulationen unterschiedlicher Individuendichte. PhD dissertation, Justus-Liebig-Universität Gießen, Germany

Hüls J, Otte A, Eckstein RL (2007) Population life-cycle and stand structure in dense and open stands of the introduced tall herb Heracleum mantegazzianum. Biological Invasions 9:799-811

Julia R, Holland DW, Guenthner J (2007) Assessing the economic impact of invasive species: The case of yellow starthistle (Centaurea solsitialis L.) in the rangelands of Idaho, USA. Journal of Environmental Management 85:876-882

Kahmen A, Perner J, Audorff V, Weisser W, Buchmann N (2005) Effects of plant diversity, community composition and environmental parameters on productivity in montane European grasslands. Oecologia 142:606-615 
Kataria M (2007) A cost-benefit analysis of introducing a non-native species: The case of signal crayfish in Sweden. Marine Resource Economics 22:15-28

Kennedy TA, Naeem S, Howe KM, Knops JMH, Tilman D, Reich PB (2002) Biodiversity as a barrier to ecological invasion. Nature 417:636-638

Knops JMH, Tilman D, Haddard NM, Naeem S, Mitchell CE, Haarstad J, Ritchie ME, Howe KM, Reich PB, Siemann E, Groth J (1999) Effects of plant species richness on invasion dynamics, disease outbreaks, insect abundances and diversity. Ecology Letters 2:286-293

Lanta V, Leps J (2008) Effect of plant species richness on invasibility of experimental plant communities. Plant Ecology 198:253-263

Law R, Weatherby AJ, Warren PH (2000) On the invasibility of persistent protist communities. Oikos 88:319-326

Levine JM, Adler PB, Yelenik SG (2004) A meta-analysis of biotic resistance to exotic plant invasions. Ecology Letters 7:975-989

Lowell SJ, Stone SF and Fernandez L (2006) The economic impact of aquatic invasive species: a review of the literature. Agricultural and Resource Economics Review 35: 195-208

Lucey J (1994) Records of the giant hogweed, Heracleum mantegazzianum Sommier and Levier, along southern Irish rivers and streams with a revised distribution map for the region. Bulletin of the Irish Biogeographical Society 17:2-6

Marggraf R (2005) Ökonomische Grundlagen der Umweltbewertung. In: Marggraf R, Bräuer I, Fischer A, Menzel S, Stratmann U, Suhr A (eds) Ökonomische Bewertung bei umweltrelevanten Entscheidungen. Metropolis, Marburg, p 61-83

Meinlschmidt E, Dittrich R (2005) Investigations into the chemical control of Heracleum mantegazzianum. Accessed 18 August 08 ww.smul.sachsen.de/de/wu/Landwirtschaft/ download/pflanzliche_Erzeugung/Poster_HERMA_2005_final.pdf

Meyerhoff J, Hartje V (2006) Kosten-Nutzen-Analyse für den Waldumbau nach LÖWE. In: Meyerhoff J, Hartje V, Zerbe S (eds) Biologische Vielfalt und deren Bewertung am Beispiel des ökologischen Waldumbaus in den Regionen Solling und Lüneburger Heide. Forschungszentrum Waldökosysteme der Universität Göttingen, Göttingen, p 191-209

Moore JL, Mouquet N, Lawton JH, Loreau M (2001) Coexistence, saturation and Invasion resistance in simulated plant assemblages. Oikos 94:303-314 
Mwangi PN, Schmitz M, Scherber C, Roscher C, Schumacher J, Scherer-Lorenzen M, Weisser WW, Schmid B (2007) Niche pre-emption increases with species richness in experimental plant communities. Journal of Ecology 95:65-78

Naeem S, Knops JMH, Tilman D, Howe KM, Kennedy T, Gale S (2000) Plant diversity increases resistance to invasion in the absence of covarying extrinsic factors. Oikos 91:97-108

Nehrbass N, Winkler E (2007) Is the Giant Hogweed still a threat? An individual-based modelling approach for local invasion dynamics of Heracleum mantegazzianum. Ecological Modelling 201:377-384

Nielsen C, Ravn HP, Nentwig W, Wade M (2005) The Giant Hogweed Best Practice Manual. Guidelines for the management and control of an invasive weed in Europe. Forest \& Landscape Denmark, Hoersholm

Nielsen C, Vanaga I, Treikale O, Priekule I (2007) Mechanical and chemical control of Heracleum mantegazzianum and H. sosnowskyi. In: Pyšek P, Cock MJW, Nentwig W, Ravn HP (eds) Ecology and management of Giant Hogweed (Heracleum mantegazzianum). CAB International:226-239

Niesar CM, Geisthoff N (1999) Bekämpfung des Riesenbärenklaus mittels Glyphosaten. AFZ-Der Wald 22:1173-1175

Noxious Weed Control Program (2003) King County Noxious Weed List. Giant hogweed (Heracleum mantegazzianum). Accessed 19 November 07 http://dnr.metrokc.gov/wlr/LANDS/weeds/hogweed.htm

Nunes P, Markandya A (2008) Economic value of damage caused by marine bioinvasions: lessons from two European case studies. Journal of Marine Science 65:775780

Ochsmann J (1996) Heracleum mantegazzianum Sommier \& Levier (Apiaceae) in Germany. Studies on biology, distribution, morphology and taxonomy. Feddes Repertorium, 107:557-595

Olson LJ (2006) The economics of terrestrial invasive species: a review of the 13 literature. Agricultural and Resource Economics Review 35: 178-194

Panzacchi M, Bertolino S, Cocchi R, Genovesi P (2007) Population control of coypu Myocastor coypus in Italy compared to eradication in UK: a cost-benefit analysis. Wildlife Biology 13:159-171

Pfisterer AB, Joshi J, Schmid B, Fischer M (2004) Rapid decay of diversity-productivity 
relationships after invasion of experimental plant communities. Basic and Applied Ecology 5:5-14

Pyke CR, Thomas R, Porter RD, Hellmann JJ, Dukes JS, Lodge DM, Chavarria G (2008) Current practices and future opportunities for policy on climate change and invasive species. Conservation Biology 22:585-592

Pyšek P (1991) Heracleum mantegazzium in the Czech Republic: dynamics of spreading from the historical perspective. Folia Geobotanica 26:439-454

Rajmis S, Barkmann J, Marggraf R (2009a) Pythias Rache: Zum Tauschwert ökologischer Versicherung vor unbekannten Risiken. Submitted to GAIA - Ecological Perspectives for Science and Society

Rajmis S, Barkmann J, Marggraf R (2009b) Forest management measures to mitigate climate change or adapt to its effects: monetary preferences in the user community around Hainich National Park, Germany (accepted for Climate Research)

Richard S, Moslemi S, Sipahutar H, Benachour N, Seralini GE (2005) Differential Effects of Glyphosate and Roundup on Human Placental Cells and Aromatase. Environmental Health Perspectives 113:716-720

Schepker H (1998) Wahrnehmung, Ausbreitung und Bewertung von Neophyten. Eine Analyse der problematischen nichteinheimischen Pflanzen in Niedersachsen. Ibidem, Stuttgart

Singh BK, Shaner DL (1998) Rapid determination of glyphosate injury to plants and identification of glyphosate-resistent plants. Weed technology 12:527-530

Thiele J, Otte A (2006) Analysis of habitats and communities invaded by Heracleum mantegazzianum Somm. et Lev. (Giant Hogweed) in Germany. Phytocoenologia 36: 281-320

Thiele J, Otte A (2008) Invasion patterns of Heracleum mantegazzianum in Germany on the regional and landscape scales. Journal for Nature Conservation 16:61-71

Tiley GED, Philp B (1994) Heracleum mantegazzianum (Giant Hogweed) and its control in Scotland. In: de Waal LC, Child L, Wade PM, Brock JH (eds) Ecology and management of invasive riverside plants. Wiley and Sons, Chichester, p 101-109

Tiley GED, Felicite SD, Wade PM (1996) Biological flora of the British Isles, Heracleum mantegazzianum Sommier \& Levier. Journal of Ecology 84:297-319 UNEP [United Nations Environment Program] (2008) Invasive Alien Species. Convention on Biological Diversity (CBD). Accessed 19 June 08 www.cbd.int/invasive 
Chapter V

Van Ruijven J, De Deyn GB, Berendse F (2003) Diversity reduces invasibility in experimental plant communities: the role of plant species. Ecology Letters 6:910-918

Van Wilgen BW, de Wit MP, Anderson HJ and 5 others (2004) Costs and benefits of biological control of invasive alien species: case studies from South Africa. South African Journal of Science 100:113-122

Vila M, Basnou C, Pyšek, P and 8 others (2009) How well do we understand the impacts of alien species in ecosystem services? A pan-European, cross-taxa assessment. Frontiers in Ecology and the Environment. doi: 10.1890/080083

Westhus W, Fritzlar F, Klaus S, Nöllert A, Wiesner J, Knorre D, von Zimmermann W, Müller R (2006) Bedrohen invasive gebietsfremde Tiere und Pflanzen unsere heimische Natur? Ein Situationsbericht aus Thüringen. Landschaftspflege und Naturschutz in Thüringen 43:1-19 


\section{Annex}

In the following, calculations of costs for small $\left(<100 \mathrm{~m}^{2}\right)$, medium $\left(>100-1,000 \mathrm{~m}^{2}\right)$ and large areas $\left(>1000-10,000 \mathrm{~m}^{2}\right)$ are shown in some detail. Only the low-cost alternative for optimistic and pessimistic scenario for each area size was chosen for cost-benefit analysis.

Table 1. Scenario calculations for small areas $\left(<100 \mathrm{~m}^{2}\right)$

\begin{tabular}{|c|c|c|c|c|c|c|c|c|c|c|c|c|}
\hline \multirow[t]{3}{*}{ Alternative } & \multirow[t]{3}{*}{ Small area } & \multicolumn{10}{|c|}{ Calculation period in years } & \multirow{2}{*}{$\begin{array}{c}\text { Total costs } \\
\text { plus access } \\
\text { burden } \\
\end{array}$} \\
\hline & & \multicolumn{10}{|c|}{ Costs in $€$} & \\
\hline & & 0 & 1 & 2 & 3 & 4 & 5 & 6 & 7 & 8 & 9 & \\
\hline Optimistic & Root destruction with shovel & 363 & 35 & 35 & 34 & 33 & 33 & 32 & 32 & 31 & 30 & 791.20 \\
\hline Pessimistic & Root destruction with shovel & 363 & 35 & 35 & 339 & 33 & 33 & 32 & 309 & 31 & 30 & $1,460.50$ \\
\hline
\end{tabular}

For optimistic scenario implementation concerning small, medium and large areas (Table 1,2, and 3; first line) no more additional infestation of Heracleum mantegazzianum is suggested for a time period of ten years. For the pessimistic scenario we calculate two additional treatments for all measures in a time period of ten years (e.g. re-infestation in third and seventh year; for chemical control, costs of renaturation are included). All costs include 50\% after-treatment (if measure conducted) and monitoring (30\% of labour costs) for each year.

Table 2. Scenario calculations for medium areas $\left(>100-1,000 \mathrm{~m}^{2}\right)$

\begin{tabular}{|c|c|c|c|c|c|c|c|c|c|c|c|c|}
\hline \multirow[t]{3}{*}{ Alternative } & \multirow[t]{3}{*}{ Medium area } & \multicolumn{10}{|c|}{ Calculation period in years } & \multirow{2}{*}{$\begin{array}{c}\text { Total costs } \\
\text { plus access } \\
\text { burden } \\
\end{array}$} \\
\hline & & \multicolumn{10}{|c|}{ Costs in $€$} & \\
\hline & & 0 & 1 & 2 & 3 & 4 & 5 & 6 & 7 & 8 & 9 & \\
\hline Optimistic & Chemical control & 2,940 & 162 & 159 & 156 & 153 & 150 & 147 & 144 & 142 & 139 & $5,092.20$ \\
\hline Pessimistic & Chemical control & 2,940 & 162 & 159 & 2717 & 153 & 150 & 147 & 2,446 & 142 & 139 & $10,683.50$ \\
\hline
\end{tabular}

For year ' 0 ' we assume cost of labour, cost of material for one treatment, after-treatment ( $50 \%$ of total costs) and monitoring ( $30 \%$ of labour costs). For year ' 1 ' to ' 9 ' we assume monitoring costs $(30 \%$ of labour costs) in optimistic scenario calculations. In pessimistic scenario calculations, the same conditions are suggested except for year ' 3 ' and year ' 7 ', 


\section{Chapter V}

where we assume re-infestation. For these two years, control, treatment and after-treatment (restoration for chemical control) are calculated additionally. Optimistic scenario calculations are based on the following assumptions:

$$
\begin{aligned}
& \text { Costs }\left(\text { year }_{0}\right)=\text { control }+ \text { labour }+ \text { material } \\
& \text { Costs }\left(\text { year }_{1}\right)=\frac{\text { control } * 1.04}{1.06} \\
& \text { Costs }\left(\text { year }_{\mathrm{x}}\right)=\frac{\text { Labour }^{*} 1.04^{x}}{1.06^{x}}
\end{aligned}
$$

Pessimistic scenario calculations are based on assumptions below:

Costs $(3$ rd and 7 th year $)=\frac{\text { control } * 1.04^{x}}{1.06^{x}}+\frac{\text { labour } * 1.04^{x}+\text { material } * 1.03^{x}}{1.06^{x}}$

Except for year 3 and 7 pessimistic scenario is calculated as shown in the optimistic scenario

\begin{tabular}{|c|c|c|c|c|c|c|c|c|c|c|c|c|}
\hline \multirow[t]{2}{*}{ Alternative } & \multirow[t]{3}{*}{$\overline{\text { Large area }}$} & \multicolumn{10}{|c|}{ Calculation period in years } & \multirow{2}{*}{$\begin{array}{c}\text { Total } \\
\text { costs plus } \\
\text { access } \\
\text { burden } \\
\end{array}$} \\
\hline & & \multicolumn{10}{|c|}{$\overline{\text { Costs in } €}$} & \\
\hline & & $\overline{\overline{0}}$ & $\overline{\overline{1}}$ & $\overline{\overline{2}}$ & $\overline{\overline{3}}$ & $\overline{\overline{4}}$ & $\overline{55}$ & $\overline{\overline{6}}$ & $\overline{77}$ & $\overline{88}$ & $\overline{99}$ & \\
\hline Optimistic & $\begin{array}{c}\text { Mechanical } \\
\text { cutting }\end{array}$ & 32,893 & 612 & 601 & 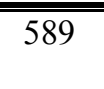 & 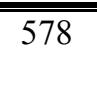 & 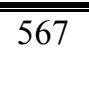 & 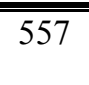 & 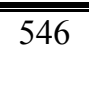 & 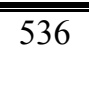 & 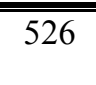 & $\overline{444,299.15}$ \\
\hline Pessimistic & Grazing & 7,545 & 3,703 & 3,645 & 3,590 & 3,539 & 3,492 & 3,448 & 3,407 & 3,370 & 3,337 & $48,739.30$ \\
\hline
\end{tabular}
analysis (1)-(3).

Table 3. Scenario calculations for large areas $\left(>1,000-10,000 \mathrm{~m}^{2}\right)$

Due to grazing is a regularly conducted measure, we assume grazing as pessimistic scenario (re-infestations could appear at any time suggesting a total time period of ten years). For year ' 0 ' costs of labour and materials are calculated. For the following years ' 1 ' to ' 9 ' costs of labour and running costs are calculated. Again, we assume 1\% increase of labor costs (pay increase), $3 \%$ inflation rate and $6 \%$ discounting (material costs) per year: 
Chapter V

Costs $\left(\right.$ year $\left._{0}\right)=$ labour + material

Costs $\left(\right.$ year $\left._{1}\right)=\frac{\text { Labour } * 1.04+\text { running } \cos t s * 1.03}{1.06}$

Costs $\left(\right.$ year $\left._{\mathrm{x}}\right)=\frac{\text { Labour }^{*} 1.04^{x}+\text { running } \cos t s * 1.03^{x}}{1.06^{x}}$ 


\section{Appendix I: Questionnaire (German version)}

\section{Fragebogen}

Um Maßnahmen in der Naturschutz- und Landschaftsplanung zu entwickeln, ist es wichtig, die Unterschiede der Wälder zu berücksichtigen. Einige Wälder haben z.B. eine hohe Widerstandskraft gegen Schädlinge oder Windwurf, andere dagegen eine niedrige. Man kann sich daher vorstellen, dass Wälder auch unterschiedlich widerstandsfähig gegen zukünftige Gefahren sein können.

Es gibt vier Themen in diesem Fragebogen, die ich Ihnen jetzt vorstellen möchte. Anschließend werde ich Ihnen diese Karten (eine Choice Karte zeigen) zeigen und Sie bitten, sich diejenige auszusuchen, die Ihnen am Besten zusagt. Dann werde ich Ihnen noch ein paar Abschlussfragen stellen. Einverstanden?

Die vier Themen sind: 1. Gefahren durch Klimaveränderung, 2. Gefahren durch nichteinheimische Pflanzen, 3. Gefahren durch Schädlinge und Windwurf, 4. Bedrohung durch neue oder unbekannte Gefahren.

\section{Thema Nr.1: Gefahren durch Klimaveränderung}

Vielleicht haben Sie davon gehört, dass Deutschland sich in einem internationalen Abkommen dazu verpflichtet hat, den Ausstoß an den so genannten Treibhausgasen zu senken. Die meisten Wissenschaftler halten dies für wichtig. Dabei ist nicht das wärmere Wetter bei uns das eigentliche Problem, sondern die größere Gefahr von Hochwasser durch starke Regenfälle oder die Ausbreitung von Schädlingen und Krankheiten.

Haben Sie zu dem Thema schon mal etwas gehört?

Ein wichtiges Treibhausgas ist das Kohlendioxid. Eine durchschnittliche Person in Deutschland verursacht 10 Tonnen Kohlenstoffabgase pro Jahr. Die Wälder im Nationalpark Hainich binden einen Teil davon aus der Luft. Das sind ungefähr 5.400 Tonnen Kohlenstoff pro Jahr. Der Hainich kann also soviel Kohlenstoff binden, wie 540 Personen pro Jahr freisetzen. Zusätzlich beitragen kann man zu der Kohlenstoffbindung durch Anpflanzung von Bäumen.

Auf den Karten werden Sie also folgende 3 Auswahlmöglichkeiten zu diesem Thema haben:

Kohlenstoff-Bindung von 540 Personen. Das ist der jetzige Zustand in den Wäldern

Kohlenstoff-Bindung von 630 Personen.

Kohlenstoff-Bindung von 720 Personen. 
Wie wichtig ist Ihnen dieses Thema auf einer Skala von 1 bis 5 ? 1 = (I: gesprochen „entspricht“") sehr wichtig, $2=$ eher wichtig, 3 = Kann ich nicht sagen, $4=$ eher unwichtig, $5=$ völlig unwichtig (I: Zahl einkringeln)

$1 \_3$

\section{Thema Nr.2: Gefahren durch nicht-einheimische Pflanzen}

Vielleicht haben Sie schon mal von nicht-einheimischen Pflanzen gehört. Das sind Pflanzen, die ursprünglich nicht in Deutschland vorgekommen sind und meist unbeabsichtigt vom Menschen eingeschleppt wurden. Das Problem: Manche dieser Pflanzen schädigen einheimische Pflanzen oder auch den Menschen. So können sie z.B. einheimische Pflanzen verdrängen, Probleme in der Land- und Forstwirtschaft verursachen oder für den Menschen gefährlich sein. Vielleicht haben Sie schon mal vom Riesen-Bärenklau (Bild zeigen) gehört? Dessen Saft kann bei Berührung zu Brandblasen auf der Haut führen. In manchen Fällen ist nicht sicher vorhersagbar, ob diese eingewanderten Arten negative Einflüsse haben oder nicht. Auf den Karten werden Sie folgende 2 Auswahlmöglichkeiten zu diesem Thema haben:

Entfernung schädlicher nicht-einheimischer Pflanzen in Einzelfällen: entspricht dem jetzigen Zustand der Wälder im Hainich. D.h. in Einzelfällen werden besonders schädliche Pflanzen an bestimmten Standorten entfernt, um eine weitere Ausbreitung zu verhindern.

Regelmäßige, großflächige Entfernung nicht-einheimischer Pflanzen, unabhängig davon, ob sie schädlich sind oder nicht: Die nicht-einheimischen Pflanzen können aber auch regelmäßig und großflächig entfernt werden, um einen besseren Schutz vor deren möglicher Schadwirkung und Ausbreitung zu erreichen.

Haben Sie zu dem Thema schon mal etwas gehört?

Wie wichtig ist Ihnen dieses Thema auf einer Skala von 1 bis 5? $1=$ (I: gesprochen „entspricht“) sehr wichtig, $2=$ eher wichtig, $3=$ Kann ich nicht sagen, $4=$ eher unwichtig, $5=$ völlig unwichtig (I: Zahl einkringeln)

$1 \_2+3 \quad 4 \quad 5$

\section{Thema Nr.3: Gefahren durch Schädlinge und Windwurf}

Viele Wälder werden von Borkenkäfern oder anderen Schädlingen befallen. Der Wald kann sich bis zu einem gewissen Grad selbst vor Schädlingen wie dem Borkenkäfer schützen. Dies hat etwas mit den Eigenschaften der Baumarten zu tun.

So ähnlich ist es bei starkem Wind oder anderen Wetterverhältnissen. Bis zu einem gewissen Grad kann sich der Wald davor schützen. Man kann die Bedingungen für den Wald aber auch verbessern, damit er sich besser vor solchen Gefahren schützen kann. Auf den Karten werden Sie folgende 3 Auswahlmöglichkeiten zu diesem Thema haben: 
Hohe Widerstandskraft gegen Schädlinge \& Windwurf - Durch entsprechende Maßnahmen könnte die Widerstandskraft der Wälder im Hainich gegen Schädlinge \& Windwurf erhöht werden. Z.B. durch die Anpflanzung von standorttypischen Bäumen.

Mittlere Widerstandskraft gegen Schädlinge \& Windwurf - Das ist in etwa der jetzige Zustand der Wälder im Hainich.

Geringe Widerstandskraft gegen Schädlinge \& Windwurf - Wälder mit Baumarten, die nicht unbedingt an den Standort angepasst sind für Schädlinge oder Wettereinflüsse in der Regel am anfälligsten. In der Vergangenheit wurden oft ganze Wälder mit nur einer standortuntypischen Baumart gepflanzt.

Info für Interviewer bei Nachfrage: Bei der letzten Möglichkeit (Geringe Widerstandskraft gegen Schädlinge und Windwurf) würde man die Flächen mit standortuntypischen Baumarten einfach beibehalten und eventuell weiterhin Flächen mit standortuntypischen Baumarten aufforsten.

Haben Sie zu dem Thema schon mal etwas gehört?

Wie wichtig ist Ihnen dieses Thema auf einer Skala von 1 bis 5? $1=$ (I: gesprochen „entspricht") sehr wichtig, $2=$ eher wichtig, $3=$ Kann ich nicht sagen, $4=$ eher unwichtig, $5=$ völlig unwichtig (I: Zahl einkringeln)

$1 \_3 \quad 3 \quad 4 \quad 5$

Nun möchten wir gerne wissen, ob Sie der folgenden Aussage zustimmen oder diese ablehnen:

$\begin{array}{ccccc}\text { Ich } & \begin{array}{c}\text { Stim- } \\ \text { me }\end{array} & \begin{array}{c}\text { Kann } \\ \text { ich }\end{array} & \begin{array}{c}\text { Lehne } \\ \text { eher ab }\end{array} & \begin{array}{c}\text { Lehne } \\ \text { völlig ab }\end{array} \\ \text { völlig } & \begin{array}{c}\text { eher } \\ \text { nucht }\end{array} & \begin{array}{c}\text { nichme } \\ \text { sugen }\end{array} & & \end{array}$

Die Bedrohung der Wälder durch Ereignisse wie Stürme macht mir Sorgen.

\section{Thema Nr.4: Bedrohung durch unbekannte Gefahren}

Damit die Bäume besser Nährstoffe aus dem Boden aufnehmen könnten, gehen Sie oftmals „Partnerschaften“ so genannte „Symbiosen“ mit Pilzen ein. Der Pilz liefert dem Baum z.B. Stickstoff, Phosphor und Wasser. Der Baum gibt dem Pilz dafür Zucker. Dieser Pilz befindet sich an den Wurzeln des Baumes.

Außerdem schützt der Pilz den Baum vor Krankheiten und Stressfaktoren wie Trockenheit, Wärme oder Frost. Auch von den Auswirkungen des Sauren Regens kann der Pilz den Baum schützen. Zudem hält der Pilz Stoffe zurück, die sonst in die Baumwurzeln eindringen würden, z.B. Schwermetalle. Es wäre z.B möglich, dass der Pilz noch andere schädliche Stoffe zurückhält, die wir jetzt noch nicht kennen, da sie vielleicht erst in ein paar Jahren zum Vorschein kommen. Angesichts dieser Unsicherheit über zukünftige Gefahren, die zur Zeit noch nicht bekannt sind, wäre es z.B. eine Risiko-Schutz-Strategie, solche 
Appendix

Baumwurzelpilze zu fördern. Falls dann in Zukunft eine neue Gefahr auf uns zukommt, könnte dieser Pilz unsere Bäume und damit auch den Wald schützen.

Was sind die schlimmsten Auswirkungen, die Sie sich durch eine neue unbekannte Naturgefahr vorstellen können?

Auf den Karten werden Sie folgende 3 Auswahlmöglichkeiten zu diesem Thema haben:

Hohe Widerstandskraft gegen unbekannte Gefahren - Hohe Artenzahl von Baumwurzelpilzen. Die Entnahme von Bäumen aus dichten dunklen Altbeständen würde die Produktion von Baumwurzelpilzen verbessern.

Mittlere Widerstandskraft gegen unbekannte Gefahren - durch mittlere Artenzahl von Baumwurzelpilzen. Das ist in etwa der jetzige Zustand in vielen Wäldern im Hainich.

Geringe Widerstandskraft gegen unbekannte Gefahren - Geringe Artenzahl von Baumwurzelpilzen. Diese hätte man, wenn man die Standorte nicht weiter fördern würde, die jetzt nur wenige Baumwurzelpilze haben.

WICHTIG I: Reaktion des Befragten? Wenn verunsicherter Blick, fragen: Die Sache ist ein bisschen kompliziert, ich erläutere das Thema gerne noch mal, wenn Sie möchten! (Thema 4 wiederholen)

I: Wurde nach dem Zusammenhang mit der Vielfalt gefragt? (Z.B. Wie wollen Sie diesen Schutz denn umsetzen? Antwort: eine hohe Vielfalt an Baumwurzelpilzen bietet einen besseren Schutz vor unbekannten Gefahren. Durch entsprechende Maßnahmen würde man diese Vielfalt an Baumwurzelpilze fördern und verbessern ) $\quad \square$ Ja $\quad \square$ Nein

Wie wichtig ist Ihnen dieses Thema auf einer Skala von 1 bis 5? $1=$ (I: gesprochen „entspricht") sehr wichtig, $2=$ eher wichtig, $3=$ Kann ich nicht sagen, $4=$ eher unwichtig, $5=$ völlig unwichtig (I: Zahl einkringeln)

$1 \_2 \quad 3 \quad 4 \quad 5 \quad 5$

Nun möchten wir gerne wissen, ob Sie den folgenden Aussagen zustimmen oder diese ablehnen:

Wenn neue unbekannte Naturgefahren eintreten, kann es zu einer schwerwiegenden ökologischen Katastrophe kommen.

Wenn neue unbekannte Naturgefahren eintreten, können Menschenleben gefährdet werden.

Ich könnte mir vorstellen, dass neue unbekannte Naturgefahren eintreten.

Ich fühle mich dadurch bedroht, dass wir die Folgen unseres Handelns schwer abschätzen können.

$\begin{array}{ccccc}\begin{array}{c}\text { Ich } \\ \text { stimme }\end{array} & \begin{array}{c}\text { Stim- } \\ \text { me } \\ \text { völlig }\end{array} & \begin{array}{c}\text { Kann } \\ \text { icher }\end{array} & \begin{array}{c}\text { Lehne } \\ \text { nicht }\end{array} & \begin{array}{c}\text { Lehner ab } \\ \text { völlig ab }\end{array} \\ \text { zu } & \text { zu } & \text { sagen } & & \\ & & & \end{array}$

(a)




\section{I: Erklärung zu den potentiellen Kosten am Ende jeder Seite}

Sie haben bei den Karten jeweils drei verschiedene Auswahlmöglichkeiten zur Verfügung. Für jede Auswahlmöglichkeit ist ein „Preis“ am Ende der Seite aufgelistet.

Dies wären Kosten, die in Form einer so genannten Sonderabgabe im Gebiet des Hainichs zu entrichten wären. Das bedeutet, dass das Geld tatsächlich nur für Schutzmaßnahmen im Hainich verwendet werden darf.

Diese Sonderabgabe wird entweder eingeführt oder nicht. Wenn ja, dann könnte die Sonderabgabe - abhängig von Ihrer Wahl im Fragebogen - zwischen 5 und 80 Euro im Jahr betragen.

\section{Nun möchten wir gerne wissen, ob Sie den folgenden Aussagen zustimmen oder diese ablehnen:}

Die Forstverwaltung kann eine verbesserte Vorsorge-Situation im Hainich gegen neue unbekannte Gefahren bewirken.

Mit meinem finanziellen Beitrag kann eine verbesserte Vorsorge-Situation gegen neue unbekannte Gefahren erreicht werden.

$\begin{array}{ccccc}\begin{array}{c}\text { Ich } \\ \text { stimme } \\ \text { völlig }\end{array} & \begin{array}{c}\text { Stim- } \\ \text { me } \\ \text { eher }\end{array} & \begin{array}{c}\text { Kann } \\ \text { ich } \\ \text { nicht }\end{array} & \begin{array}{c}\text { Lehne } \\ \text { eher ab }\end{array} & \begin{array}{c}\text { Lehne } \\ \text { völlig ab }\end{array} \\ \text { zu } & \text { zu } & \text { sagen } & & \\ & & & \end{array}$

zu zu sagen

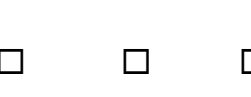

\section{Für Interviewer: Es folgt das Choice Experiment}

Jetzt möchte ich Ihnen diese Karten zeigen (Choice Karten zeigen) und Sie bitten, jeweils die Karte auszuwählen, die Ihnen am Besten zusagt. Insgesamt möchte ich Sie 8 mal um eine Auswahl bitten. Es gibt jedes Mal eine Maßnahme A und eine Maßnahme B (Karten zeigen). Daneben haben Sie die Möglichkeit, den jetzigen Zustand zu wählen - also so wie die Situation jetzt gerade im Hainich ist (Karte zeigen). Der jetzige Zustand kostet immer 0 Euro, die Kosten für Maßnahme A und B sind immer unterschiedlich.

Block Nr.:

\begin{tabular}{|l|l|l|l|l|}
\hline Choice Set & A & B & SQ & Anmerkungen \\
\hline 1 & & & & \\
\hline 2 & & & & \\
\hline 3 & & & & \\
\hline 4 & & & & \\
\hline 5 & & & & \\
\hline 6 & & & & \\
\hline 7 & & & & \\
\hline 8 & & & & \\
\hline
\end{tabular}


Jetzt, nachdem Sie die möglichen Maßnahmen auf den Karten gesehen haben, würde ich Sie gerne noch einmal fragen, wie wichtig Ihnen die vier Themen des Fragebogens sind:

Gefahren durch Klimaveränderung

Wie wichtig ist Ihnen dieses Thema auf einer Skala von 1 bis 5? $1=$ (I: gesprochen „entspricht“) sehr wichtig, $2=$ eher wichtig, $3=$ Kann ich nicht sagen, $4=$ eher unwichtig, $5=$ völlig unwichtig (I: Zahl einkringeln)

$1 \_3$

\section{Gefahren durch nicht-einheimische Pflanzen}

Wie wichtig ist Ihnen dieses Thema auf einer Skala von 1 bis 5 ? $1=$ (I: gesprochen „entspricht“) sehr wichtig, $2=$ eher wichtig, $3=$ Kann ich nicht sagen, $4=$ eher unwichtig, $5=$ völlig unwichtig (I: Zahl einkringeln)

$1 \_3 \quad 3 \quad 4 \quad 5$

Gefahren durch Schädlinge und Windwurf

Wie wichtig ist Ihnen dieses Thema auf einer Skala von 1 bis 5? $1=(\mathrm{I}$ : gesprochen „entspricht“") sehr wichtig, $2=$ eher wichtig, $3=$ Kann ich nicht sagen, $4=$ eher unwichtig, $5=$ völlig unwichtig (I: Zahl einkringeln)

$1 \_2 \_$_ 3

Bedrohung durch unbekannte Gefahren

Wie wichtig ist Ihnen dieses Thema auf einer Skala von 1 bis 5? $1=$ (I: gesprochen „entspricht") sehr wichtig, $2=$ eher wichtig, $3=$ Kann ich nicht sagen, $4=$ eher unwichtig, $5=$ völlig unwichtig (I: Zahl einkringeln)

$1 \_3$

Für wie wahrscheinlich oder ungewiss halten Sie es, dass die Maßnahmen mit dem von Ihnen auf den Karten ausgewählten $\begin{array}{ccccc}\begin{array}{c}\text { Sehr } \\ \text { wahr- }\end{array} & \begin{array}{c}\text { Eher } \\ \text { wahr- }\end{array} & \begin{array}{c}\text { Kann } \\ \text { ich }\end{array} & \begin{array}{c}\text { Eher } \\ \text { ungewiss }\end{array} & \begin{array}{c}\text { Sehr } \\ \text { Un- } \\ \text { gewiss }\end{array} \\ \begin{array}{c}\text { schein- } \\ \text { schein- } \\ \text { lich }\end{array} & \begin{array}{c}\text { nicht } \\ \text { lich }\end{array} & \text { sagen } & & \text { sewish }\end{array}$ Beträgen umgesetzt werden können?

In den Nachrichten oder in der Zeitung ist oft von unterschiedlichen Gefahren oder Problemen die Rede. 
Appendix

Für wie wahrscheinlich oder ungewiss halten Sie die folgenden Bedrohungen?

Klimaveränderung durch die Abholzung von Wäldern

\begin{tabular}{|c|c|c|c|}
\hline $\begin{array}{l}\text { Sehr } \\
\text { wahr- } \\
\text { schein- }\end{array}$ & $\begin{array}{l}\text { Eher } \\
\text { wahr- } \\
\text { schein- }\end{array}$ & $\begin{array}{c}\text { Kann } \\
\text { ich } \\
\text { nicht }\end{array}$ & $\begin{array}{c}\text { Eher } \\
\text { ungewiss }\end{array}$ \\
\hline
\end{tabular}

Die Bedrohung durch neue unbekannte Naturgefahren

Mehr Schädlinge \& Windwurf in Wäldern durch

standortuntypische Baumarten

Neue unbekannte Naturgefahren, die durch fehlende

Artenvielfalt im Wald Schaden verursachen

Die Folgen von neuen Naturgefahren werden sich auch auf mein Leben auswirken

Dass die Widerstandskraft der Wälder verloren geht und damit alle positiven Wirkungen

Neue unbekannte Naturgefahren als Folge der Zerstörung von Wäldern

Nun möchten wir gerne wissen, ob Sie den folgenden Aussagen zustimmen oder diese ablehnen:

Es ist mir wichtig, dass der Wald erhalten bleibt

$\begin{array}{ccccc}\begin{array}{c}\text { Ich } \\ \text { stimme }\end{array} & \begin{array}{c}\text { Stim- } \\ \text { me }\end{array} & \begin{array}{c}\text { Kann } \\ \text { ich }\end{array} & \begin{array}{c}\text { Lehne } \\ \text { eher ab }\end{array} & \begin{array}{c}\text { Lehne } \\ \text { völlig ab }\end{array} \\ \text { eher } & \begin{array}{c}\text { nicht } \\ \text { zu }\end{array} & & & \\ & \text { sugen } & & \end{array}$

Warum?

Holz ist ein wichtiger nachwachsender Rohstoff

Sie haben es gleich geschafft...

Am Ende dieses Fragebogens möchten wir sie noch um ein paar Informationen zu Ihrer Person bitten. Dabei geht es nicht um die Analyse einzelner Teilnehmer der Befragung! Ihre Daten werden vollständig anonym in die Datenauswertung einfließen!

Interviewer: ankreuzen

Weiblich $\quad \square$ Männlich

Wie alt sind Sie?

Jahre

Welches ist Ihr höchster Schulabschluss?

Kein Abschluss $\quad \square$ Hauptschule $\quad \square$ Mittlere Reife $\quad \square$ Abitur

$\square$ Fachhochschule $\quad \square$ Hochschulabschluss 
Appendix

Welchen Beruf üben Sie aus?
$\square$ Angestellt
Selbständig
$\square$ Nicht erwerbstätig
$\square$ In Ausbildung/ Student/in
$\square$ Pensioniert
$\square$ Hausfrau/mann

Ihr Netto-Einkommen (Euro/Monat)

$\begin{array}{lll}\square \text { bis } 499 & \square 1500-1999 & \square 4000 \text { und mehr } \\ \square \text { 500-999 } & \square 2000-2999 & \\ \square 1000-1499 & \square 3000-3999 & \end{array}$

Wohnort

Waren Sie schon einmal im Nationalpark Hainich?

$\square \mathrm{Ja} \quad \square$ Nein

(Interviewer: Falls ja): Wie oft in den letzten zwölf Monaten?

$\square$ Kein Mal $\square \_$Mal $\square 1$ Mal im Monat $\square 1$ Mal in der Woche

(Interviewer: Falls nein): Besuchen Sie einen anderen Wald?

$\square \mathrm{Ja}$ (Name) Wald $\quad \square$ Nein

(Interviewer: Falls ja): Wie oft in den letzten zwölf Monaten?

$\square$ Kein Mal $\square \_$Mal $\square 1$ Mal im Monat $\square 1$ Mal in der Woche

Vielen Dank, dass Sie sich für unsere Fragen Zeit genommen haben!

Falls Sie Anmerkungen oder Anregungen zu unserem Fragebogen haben, können Sie diese jetzt äußern! 


\section{Appendix II: Example of a choice set (German version)}

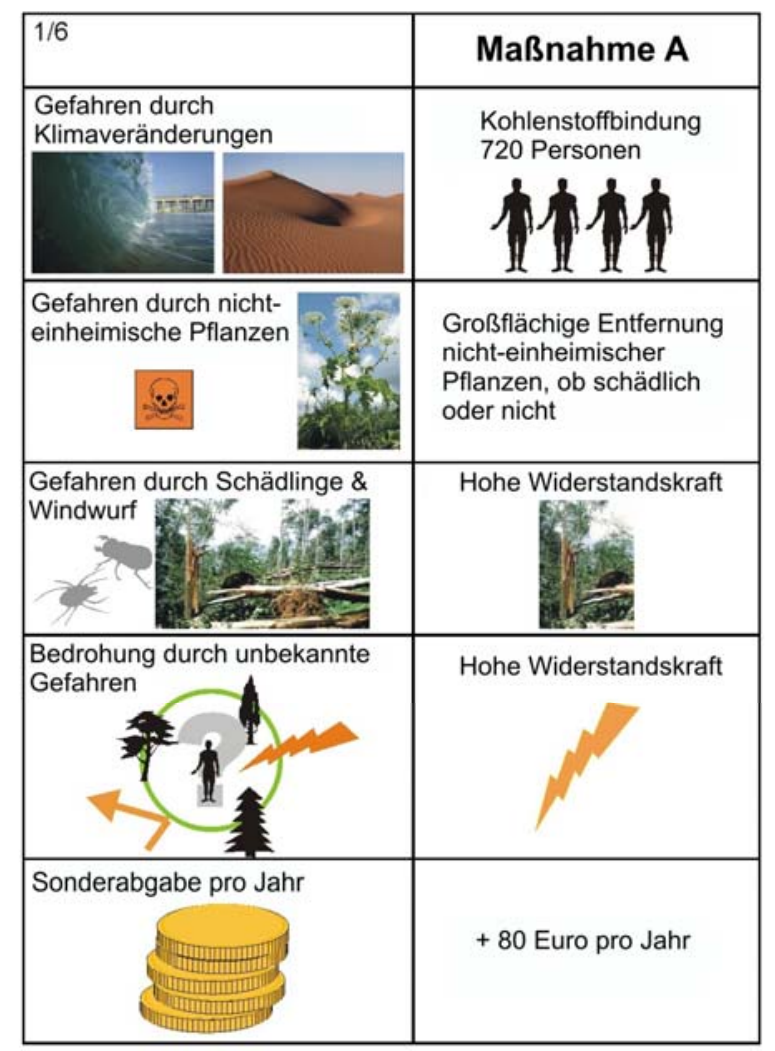

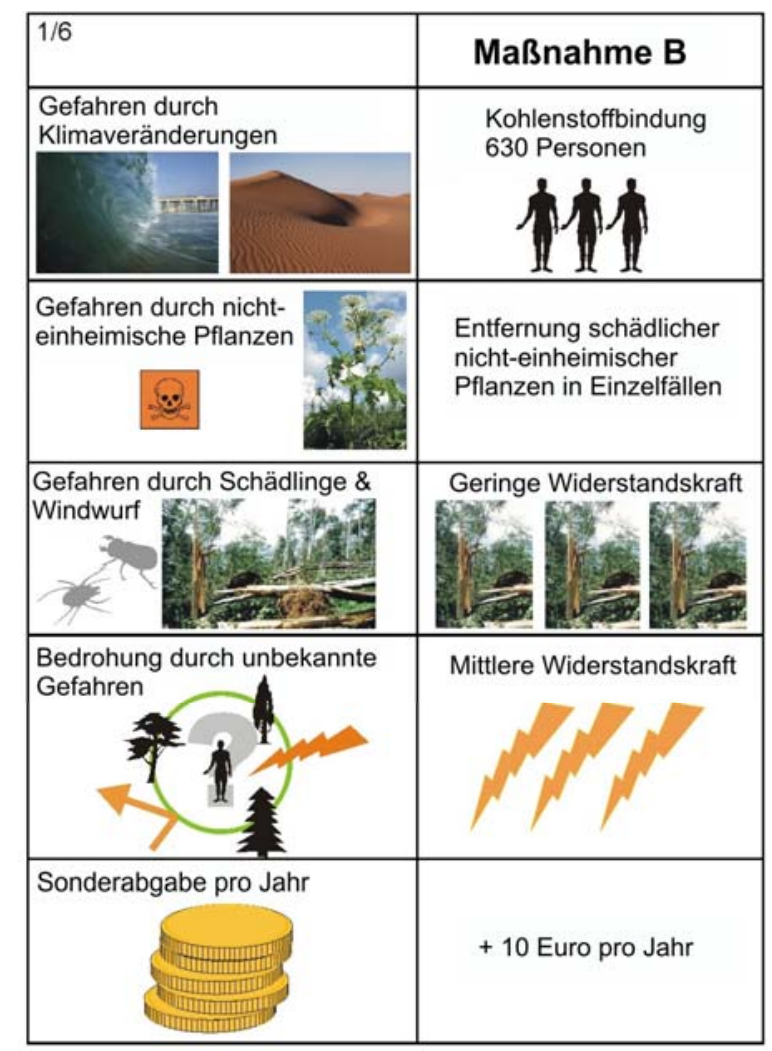

\begin{tabular}{|l|l|}
\hline & Jetziger Zustand \\
\hline $\begin{array}{l}\text { Gefahren durch } \\
\text { Klimaveränderungen }\end{array}$ & $\begin{array}{l}\text { Kohlenstoffbindung } \\
540 \text { Personen }\end{array}$ \\
\hline $\begin{array}{l}\text { Gefahren durch nicht- } \\
\text { einheimische Pflanzen }\end{array}$ & $\begin{array}{l}\text { Entfernung schädlicher } \\
\text { nicht-einheimischer } \\
\text { Pflanzen in Einzelfällen }\end{array}$ \\
\hline $\begin{array}{l}\text { Gefahren durch Schädlinge \& } \\
\text { Windwurf }\end{array}$ & $\begin{array}{l}\text { Mittlere Widerstandskraft } \\
\text { Gedrohung durch unbekannte } \\
\text { Gefahren }\end{array}$ \\
\hline
\end{tabular}




\section{Appendix III: Curriculum Vitae}

\section{$\underline{\text { Personal Details }}$}

Name:

Sandra Rajmis

Date/place of birth:

April 1, 1977 in Hildesheim (Germany)

\section{Education}

$4 / 2005-8 / 2008$

PhD student at the Department of Agricultural Economics and Rural

Development, Georg-August-Universität Göttingen. Chair: Prof. Dr.

Marggraf and PhD program Biological Diversity and Ecology

10/1998-10/2004 Master student at Universität Bielefeld, Diploma in

Environmental Sciences

10/2002-2/2003 Exchange student at Charles University Prague, Environmental

Sciences

$05 / 1997$

University entrance qualification at St. Raphael Gymnasium

Heidelberg

\section{Work experience}

Since $10 / 2007$

Research assistant for the project BIOLOG (Biodiversity and Global Change)

$2 / 2005-3 / 2005$

Intern at the German Agency for Nature Conservation in Leipzig (BfN/Außenstelle)

$6 / 2004-2 / 2005$

Student assistant at Faculty of Health Sciences, Universität Bielefeld

$5 / 2001-4 / 2002$

$3 / 2001$

Assistant at 'Biotec' company (environmental analysis)

Intern at the Environmental Administrative Office

(Staatl. Umweltamt) Bielefeld

\section{Volunteer activities}

9/1997-8/1998

Volunteer in Environmental Education Program (FÖJ)

at Administrative Office of Forestry in Oerrel/Munster

$3 / 1999-9 / 2001$

Volunteer in the organization 'Friends of Nature' in Bielefeld

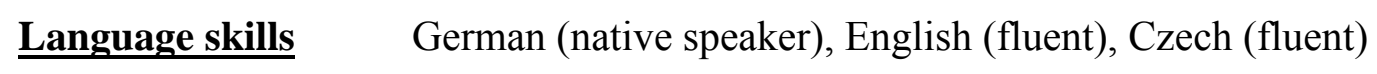

